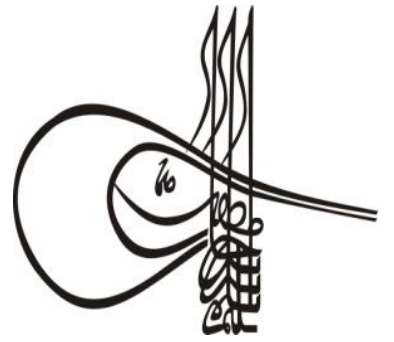

\section{Comparative Religious Studies}

Volume 14 Issue 2, 2019, p. 329-394

DOI: 10.29228/TurkishStudies.22489

ISSN: 2667-5544

Skopje/MACEDONIA-Ankara/TURKEY

Research Article / Araştırma Makalesi

Article Info/Makale Bilgisi

Received/Geliș: 07.12.2018

$\checkmark$ Accepted/Kabul: 10.06 .2019

NATIONAL

BALKAN

UNIVERSITY

EXCELLENCE FOR THE FUTURE IBU.EDU.MK

Report Dates/Rapor Tarihleri: Referee 1 (07.01.2019)-Referee 2 (08.01.2019)

This article was checked by iThenticate.

\title{
ELMALILI MUHAMMED HAMDİ YAZIR (1878-1942) VE ESERLERI HAKKINDA YAPILMIŞ ÇALIŞMALAR BİBLIYOGRAFYASI (1923-2018)
}

\author{
Ahmet Sait SICAK ${ }^{*}$ - Recep BILGIIN**
}

\begin{abstract}
ÖZET
Elmalılı M. Hamdi Yazır (1878-1942) Osmanlı Devleti'nin son dönemi ile Türkiye Cumhuriyeti'nin ilk yıllarında yaşamıştır. O; aldığı eğitim, toplumumuza kazandırdığı eserler, sosyal ve siyasi hayatı ile öne çıkan, bilhassa İslâmî ilimlerden tefsir, fikıh (hukuk) ve felsefe alanında büyük emek vermiş, müfessir, hukukçu ve siyasetçi kimliğiyle bilinen Cumhuriyet döneminin ününü hak eden çok yönlü âlimlerinden biridir. Onun en önemli eseri olarak kabul edilen Hak Dini Kur'an Dili isimli tefsiri de farklı bilim dallarına mensup araştırmacılar tarafından faydalanılacak derinliğe ve özelliğe sahiptir. Bu yönüyle Elmalılı'nın Türkiye'deki dinî araştırmalar ve genel din algısı üzerinde etkisinin büyük olduğu rahatlıkla söylenebilir. Hak Dini Kur'an Dili Cumhuriyet'in kurulussundan bugüne kadar Kur'an'in anlașılması üzerine önemli etkisi olan ve Latin harfleriyle telif edilen ilk tefsirdir. Bu özelliği dolayısıyla birçok insanın başucunda ve kütüphanelerinde yer almaktadır. Bu makale; hem Türkiye'de, hem Batı'da hem de Arap ülkelerinde Elmalılı M. Hamdi Yazır ve eserleri üzerine yapılmış çalışmaları konu alan bir literatür incelemesidir. $\mathrm{Bu}$ araștırmada, kronolojik olarak Elmalılı ve eserleri üzerine yapılmış kitap, kitap bölümleri, makale, bitirme tezi, yüksek lisans ve doktora tezleri, sempozyum bildirileri, tercüme ve sadeleştirme gibi çalışmalar ele alınmıştır.

Elmalıl1, kısaca değindiğimiz çok yönlülüğü sebebiyle, literatürde her ne kadar tefsiriyle ön planda yer alsa da tefsir ilminin yanı sıra Türkiye'de kelâm, felsefe, hukuk ve hadis gibi ilimler bașta olmak üzere birçok alanda yapılan akademik ve diğer çalışmalarda kendisinin ve
\end{abstract}

Dr. Öğr. Üyesi, Mustafa Kemal Üniversitesi, İlahiyat Fakültesi, Tefsir Anabilim Dalı, E-posta: ahsa99@ hotmail.com 
eserlerinin konu alındığı görülmektedir. Bu bağlamda yapılan araştırma neticesinde Elmalı1ı M. Hamdi Yazır; tespit edilebilinen 642 künye ve 602 yayınla kendisi ve eserleri hakkında en fazla araștırma ya pılan Cumhuriyet devri müfessiridir.

Anahtar Kelimeler: Elmalılı Muhammed Hamdi Yazır, Hak Dini Kur'an Dili, Müfessir, Tefsir, Bibliyografya, Literatür.

\title{
ELMALILI MUHAMMED HAMDI YAZIR (1878-1942) AND A BIBLIOGRAPHY OF RESEARCH ON HIS LITERATURE (1923- 2018)
}

\begin{abstract}
Elmall1 M. Hamdi Yazır (1878-1942) was lived between the lateperiod of the Ottoman Empire and the first period of the Republic of Turkey. He was one of the most prominent and educated scholars of the Republic time, who was known as an interpreter, legal expert, and also politician, and famous for his studies on Islamic sciences, tafsir, fiqh, and philosophy that he gifted them to our society. His canonic book, Hak Dini Kur'an Dili (God's Religion Koran's Language) is regarded as a comprehensive interpretation of Koran, allowed many researchers from different areas to benefit from it as a magnum opus. By this feature, it could easily be said that Elmall1 has a great influence on the perception of religion, and religious studies in Turkey. Hak Dini Kur'an Dili (God's Religion Koran's Language) is the first interpretation written with the Latin alphabet for a better understanding of Koran since the establishment of the Republic of Turkey. By this feature, it takes place in the prime bookshelf of many people and libraries.

This essay is a literature study of studies done on Elmall1 M. Hamdi Yazır and his literature including Turkey, the Western and Arabic countries. This essay includes studies such as a book, book chapters, essay, undergrad and master's theses, dissertations, conference proceedings, translations, and simplifications on Elmalil and his collection of research. Even though Elmall1 is known -as we shortly referred to his sophisticated background- mostly about his hermeneutical works, not only the tafsir but kalam, philosophy, law and, hadith are referred in the field of academics and other circles. In this context, after a result of the search, with 642 research record and 602 publications he became the most studied interpreter in the Republic time.
\end{abstract}

\section{STRUCTURED ABSTRACT}

Elmal11 M. Hamdi Yazır (1878-1942) was lived between the lateperiod of the Ottoman Empire and the first period of the Republic of Turkey. He was one of the most prominent and educated scholars of the Republic time, who was known as an interpreter, legal expert, and also politician, and famous for his studies on Islamic sciences, tafsir, fiqh, and philosophy that he gifted them to our society. His canonic book, Hak Dini Kur'an Dili (God's Religion Koran's Language) is regarded as a 
comprehensive interpretation of Koran, allowed many researchers from different areas to benefit from it as a magnum opus. By this feature, it could easily be said that Elmall1 has a great influence on the perception of religion, and religious studies in Turkey. Hak Dini Kur'an Dili (God's Religion Koran's Language) is the first interpretation written with the Latin alphabet for a better understanding of Koran since the establishment of the Republic of Turkey. By this feature, it takes place in the prime bookshelf of many people and libraries.

Even though Elmall1, as we referred to his sophisticated background, was known mostly about his tafsir works, his literature including tafsir, kalam, philosophy, law and, hadith are studied in the field of academics and other circles.

While narrowing down the scope of this research, we decided to classify our literature review into three topics;

1. Literature study on literature that tracks down the literature of Elmalil1.

2. Literature study on references of the literature of Elmalil1.

3. Literature study on research done on Elmalll and his literature.

This essay attempts to do literature research -number three topicwhich is on research that is on Elmall1 and his publications. Every single literature of Elmalili and references of his study are excluded from this study as they all need meticulous research separately. Many literature studies have been done on M. Hamdi Yazır and his literature in our country. Some factors, for instance, the date and scope of previous studies that were lack of containing many resources, also new and developing techniques motivated us to undertake this research.

This essay aimed to do literature research in the aforementioned studies happened in Turkey, in the West and Arabian countries. In addition to this, focus and depth of literature on Elmallil and his work will be covered. Hence, we will try to uncover the trend and stress of academic areas of the literature on Elmall1. While telling about the studies on Elmall1, we will mention from the time period, causes of accumulation, their language, distribution of languages of studies, classifications of type and number of studies such as; book, book chapter, thesis, essay, conference proceedings; types of thesis such as; master's or doctorate,complete or incomplete; in addition to this, sort of journals whether peer-reviewed or not; and finally the type of disciplines.

After literature review and research on Elmalı M. Hamdi Yazır and his studies, we tracked 642 record including original books in Turkish and other languages (17), book chapters (24), conference proceedings book (68), books derived from essays and thesis (3), books derived from literature of Elmalili M. Hamdi Yazır (12), tafsir (11), simplification of translation of Koran (72), bachelor's theses (111), complete and incomplete master's thesis (101), dissertations (10), peer-reviewed (90) and non-reviewed journals (44) published essays, encyclopedia articles (4), conference proceedings (75). When incomplete dissertations (2), master theses (28) and anonymous publications (10) were excluded, we left to 602 records. 
These 602 records were produced by 410 researchers. 47 of these researchers have three or more publications. The most productive researchers with 7 publications are; Dücane Cündioğlu, Mustafa Özel, Nazif Öztürk, Necmi Atik, Sabri Yılmaz, and Tahsin Görgün. Other researchers with 6 publications are; Asım Cüneyd Köksal, Fatma Paksüt, İsmail Kara, Recep K1lıç. Researchers with 5 publications; Abdullah Çolak, Halis Albayrak, İbrahim Hilmi Karsl1, İsmail Albayrak, Murat Kaya, Suat Yıldırım and Vehbi Vakkasoğlu.

Even though most of the books, book chapters and essays published in non-reviewed journals on Elmalilı and his literature, they didn't allow us to do for categorization of disciplines. After the search, we tracked in total 387 records: with the data of title, author name, content, the expertise of authors; based on 18 academic areas; including 111 bachelor's graduation theses, 73 master's thesis, 8 dissertations, in progress 28 master's thesis and 2 doctoral research, 90 peer-reviewed journal articles, 75 conference proceedings. Distribution of these studies on type of is branch of science; Tafsir 177, kalam 53, Islamic law 40, Islamic philosophy 25 , philosophy of religion 21 , hadith 17 , history and Art of Islam 14, history of religion 8, Islamic mysticism 8, education of religion 6 , sociology of religion 4, Arabic language and rhetoric 4, history of sects 3, psychology of religion 2, history 2, Modern history 1, philosophy 1 and theology/middle east studies 1 .

The first study that could be regarded on Elmalil1 and his work was published in 1923. There had been intense research in the year 1942, in which he passed away, and between 1955-1956. Since 1989, there have been studies published every year on Elmalilı on a regular base. Since 1989, there had been a conference about him every year. We found an accumulation on his studies in 1992 -in which copyrights lifted on his literature-, 1991 and 2012 -in which a conference organized on him-, 1991 and 2013 in which the conference proceedings were published. 2015 with 72 publications and 1 record and 2012 with 63 publications and 5 records were the most productive years.

In this context, Elmalilı M. Hamdi Yazır was the most studied Republic-time tafsir scholar with available 642 research record and 602 publications on his work and himself.

Keywords: Elmalıl1 Muhammed Hamdi Yazır, Hak Dini Kuran Dili, God's Religion Koran's Language, Interpreter, Tafsir, Bibliography, Literature.

\section{GíRIŞ}

Elmalılı M. Hamdi Yazır (1878-1942) Osmanlı Devleti'nin son dönemi ile Türkiye Cumhuriyeti'nin ilk yıllarında yaşamıştır. O; aldığı eğitim, toplumumuza kazandırdığ 1 eserler, sosyal ve siyasi hayatı ile öne çıkan, bilhassa İslâmî ilimlerden tefsir, fikıh (hukuk) ve felsefe alanında büyük emek vermiş, müfessir, hukukçu, filozof ${ }^{1}$ ve siyasetçi kimliğiyle bilinen Cumhuriyet döneminin ününü hak eden çok yönlü âlimlerinden biridir. Onun en önemli eseri olarak kabul edilen Hak Dini Kur'an Dili isimli tefsiri de farklı bilim dallarına mensup araştırmacılar tarafından faydalanılacak derinliğe ve

\footnotetext{
${ }^{1}$ Elmalılı, Hak Dini Kur'an Dili adlı tefsirindeki yorumlarında; mantık, doğa felsefesi, psikoloji, metafizik, ahlak ve siyaset felsefesine ilişkin düşüncelerine yer vermiştir (Sarıtaş, 2016: 182).
} 
özelliğe sahiptir. Bu yönüyle Elmalılı'nın Türkiye'deki dinî araştırmalar ve genel din algısı üzerinde etkisinin büyük olduğu rahatlıkla söylenebilir. Hak Dini Kur'an Dili Cumhuriyet'in kuruluşundan bugüne kadar Kur'an'ın anlaşılması üzerine önemli etkisi olan ve Latin harfleriyle telif edilen ilk tefsirdir. Bu özelliği dolayısıyla birçok insanın başucunda ve kütüphanelerinde yer almaktadır. Yazır'ın yaşadığı dönemin siyâsî ve sosyal olayları göz önünde bulundurulduğunda onun İslâmî ilimlere ve İslâm toplumuna yaptığı katkının önemi daha iyi anlaşılacaktır. Ayrıca Elmalılı'nın bulunduğu ilim havzası içerisinde, eserlerinde yer verdiği kaynaklar, âlimler ve onların fikirleri, kendi dönemine ait ilmî literatürü en güzel bir şekilde yansıtmaktadır. Böyle bir âlimin farklı açılardan incelenmesi, muhtelif konulardaki fikir ve yaklaşımlarının değerlendirilmesinin yanı sıra içinde yetiştiği ilmî gelenekten tevarüs ettiği mirası günümüze aktarmak açısından da büyük önem arz etmektedir. Türkiye ve dünyada bu gerekliliğin farkında olan araştırmacılar, Elmalılı ve eserleri üzerine birçok çalışma ortaya koymuştur.

Elmalılı ve eserleri üzerine yapılan mezkûr araştırmaları konu edinen bir literatür çalışmasını gerçekleştirmeyi hedefleyen bu makalede, ilgili literatürün belirlenmesinin yanı sıra Elmalılı M. Hamdi Yazır'a ilişkin araştırmaların odak noktası ve yörüngesi de tespit edilmeye çalışılacaktır. Böylelikle Elmalılı üzerine yapılan çalışmaların yoğunlaştığı alanlar ve yapılan çalışmaların gidişatının ortaya çıkartılması sağlanacaktır. Yapılan tespitlerle Elmalılı'nın ve Hak Dini Kur'an Dili adlı eseri başta olmak üzere eserlerinin derinlik, çeşitlilik ve zenginliği ortaya konulmuş, öte yandan Yazır ve eserleriyle ilgili hangi alanların dikkatlerden kaçtı̆̆ının ve bu husustaki yeni alanların belirlenmesi araştırmacılara kolaylaştırılmış olacaktır. Elmalılı üzerine yapılan araştırmaların serencamı aktarılırken: $\mathrm{Bu}$ çalışmaların hangi tarih aralıklarında yoğunlaştıkları ve bu yoğunluğun sebepleri, hangi dilde yayımlandıkları, yabancı dilde yapılan çalışmaların hangi dillerde kümelendiği, araştırmaların kitap, kitap bölümü, tez, makale, bildiri şeklinde tasnifi ve sayıları; tezlerin kendi içinde bitirme, yüksek lisans ve doktora olarak ayrımları; makalelerin hakemli ve hakemsiz olarak tasnifi ve bu çalışmaların tefsir, İslam hukuku, kelam, İslam felsefesi, hadis, tasavvuf, Arap dili ve belagatı, din sosyolojisi, din psikolojisi, dinler tarihi, din eğitimi ve tarih gibi hangi disiplinlerde ortaya konulduklarına dair hususlar temel tasnif kriterlerini oluşturmaktadır. Bu tasnifler yapılırken aynı bilim dalında yeteri kadar eser bulunduğunda tasnif bilim dalına göre yapılacaktır. Aynı bilim dalında bulunan eserler yeterli sayıya ulaşmadığında ise anabilim dalına göre düzenlenecektir.

Araştırmacı Esra Gözeler, Türkiyede tefsir alanında ortaya konan ürünlerin genel gidişatına ${ }^{2}$ bakıldığında ve tefsir tarihi tezleri içerisinde müfessirler ve tefsirleri hakkında yapılan tezler incelediğinde şöyle bir sonuçla karşılaşıldığını ifade etmektedir: Müfessirler içerisinde en fazla çalışma er-Râzî (v. 606/1210) ve tefsiri üzerine yapılmıştır. er-Râzî’ yi sırayla Zemahşerî (v. 538/1144), Elmalı1ı M. Hamdi Yazır (1878-1942), el-Mâturîdî (v. 333/944), et-Taberî (v. 310/923), el-Âlûsî (v. 1270/1854), İbn Kesîr (v. 744/1373), el-Kurtubî (v. 671/1273), Mukatil b. Süleymân (v. 150/767), el-Beydâvî (v. 685/1286) ve İsmail Hakkı Bursevî'ye (v. 1137/1725) dair yapılan araştırmalar takip etmektedir (Gözeler, 2016: 96). Bu ifade, üzerinde en fazla araştırma yapılan üçüncü müfessir olarak Elmalılı ve eserlerine dair yapılan çalışmalar hakkında bir literatür araştırmasını gerekli kılmaktadır. Ayrıca sayısal olarak ulaştı̆̆ımız sonuçlar sebebiyle yapılan sıralamanın tam manasıyla doğru olup olmadığına dair, sayıların net olarak ortaya konulduğu her müfessir ve eseri için ayrıca yapılmış çalışmalara ihtiyaç duyulduğu görülmektedir. Yaptığımız bu araştırma mezkûr ihtiyacın bir kısmını karşılayacak böylelikle diğer müfessirlerle kıyaslanma açısından net bilgilere ulaşılmış olunacaktır.

Yapılan literatür çalışmasının sınırları belirlenirken Elmalılı üzerine yapılacak literatür çalışmalarının üç genel başlıkta sınıflandırılabileceği görülmüştür:

\footnotetext{
2 Türkiyede tefsir alanında ortaya konan ürünlerin genel gidişatını gösteren çalışmalar için bkz. (Gözeler, 2009: 91-103; Kara, 2010: 607-636; Tuncer, 2012: 149-177; Kara, 2015; 6-269).
} 
1. Elmalılı'nın eserlerini tespit eden literatür çalışmaları ${ }^{3}$

2. Elmalılı'nın eserlerinin kaynaklarına dair yapılan literatür çalışmaları ${ }^{4}$

3. Elmalılı ve eserleri üzerine yapılan araştırmaları konu edinen literatür çalışmaları

Bu makalede üçüncü başlıkta ifade edilen "Elmalılı ve eserleri üzerine yapılan araştırmaları konu edinen literatür" ortaya konulmaya çalışılacaktır. Her biri ayrı birer makale konusu olma hüviyetine sahip; Elmalılı'nın eserleri veya Elmalılı'nın eserlerinin kaynakları bu makalenin kapsamı dışında bırakılmıştır.

$\mathrm{Bu}$ araştırma için İslam Araştırmaları Merkezi'nin (ISAM) kütüphane kataloğ $\mathrm{u}^{5}$ ile İlahiyat Fakülteleri Tezler ${ }^{6}$ ve İlahiyat Makaleler ${ }^{7}$ Veri Tabanlarına müracaat edilmiştir. Ayrıca Batı'da ve Arap dünyasında yapılan çalışmaları tespit edebilmek için çeşitli kütüphanelerin katalogları ve elektronik kaynaklar taranmıştır. Taranan kütüphane katalogları şunlardır: Milli Kütüphane, ${ }^{8}$ Ulusal Toplu Katalog, ${ }^{9} \quad$ Ankara Üniversitesi (E-Kaynaklar) ${ }^{10}$ ve Marmara Üniversitesi İlahiyat Fakültesi Kütüphanesi ${ }^{11}$ başta olmak üzere Türkiye'de bünyesinde İlahiyat Fakültesi veya İslamî İlimler Fakültesi bulunan tüm üniversitelerin kütüphane ve dökümantasyon daire başkanlıklarına ait kataloglar, Harvard University Library Catalog, ${ }^{12}$ Pontificio Istituto di Studi Arabi e d'Islamistica (PISAI) Library Catalog, ${ }^{13}$ SOAS (School of Oriental and African Studies) Library ${ }^{14}$ ve Staatsbibliothek zu Berlin. ${ }^{15}$ İncelenen elektronik kaynaklar şunlardır: The Database of Arabic Literatüre in Western Research (DAL), ${ }^{16}$ JSTOR Art \& Science I-II-III Collections, ${ }^{17}$ EBSCOhost ${ }^{18}$ ve Al Manhal Platform. ${ }^{19}$ Ayrica bu konuda önceden yapılmış olan eserlerin kaynakçaları, Mustafa Özel'in "Hak Dini Kur'ân Dili Üzerine Yapılan Akademik Çalışmalar", ${ }^{20}$ İshak Özgel'in "Elmalılı Muhammed Hamdi Yazır'ın Tefsiri ve Hakkında

\footnotetext{
${ }^{3}$ Başta İsmet Ersöz’ün doktora tezi (1985: 41-48) olmak üzere birçok yüksek lisans çalışmasında -Abdurrahman Bestil (2004: 10), Saliha Tekiner (2006: 10) ve Bestami Gözalan (2007: 5-6) vd- ve Kâmil Büyüker'in makalesinde (2017: 587-593) bu konu ele alınmıştır.

${ }^{4}$ İsmet Ersöz (1985: 65-84) ve Mustafa Özel (1999: 14-34) doktora tezlerinde bu konuyu ele almaktadırlar.

$5<$ http://ktp.isam.org.tr/> (erişim: 29 Ekim 2018).

${ }^{6}<\mathrm{http}: / /$ ktp.isam.org.tr/?url=tezilh/findrecords.php> (erişim: 29 Ekim 2018).

7 <http://ktp.isam.org.tr/?url=makaleilh/findrecords.php> (erişim: 29 Ekim 2018).

8 <https://kasif.mkutup.gov.tr/> "Hak dini", 149; "Hamdi Yazır" 673 ve "Elmalılı" 714 sonuç içerisinden (erişim: 14 Kasım 2018).

${ }^{9}<$ http://www.toplukatalog.gov.tr/index.php?cwid=2> (erişim: 29 Ekim 2018).

10 <http://kutuphane.ankara.edu.tr/?page_id=93> "Hak dini", 773; "Hamdi Yazır" 142 ve "Elmalılı" 173 sonuç içerisinden (erişim: 29 Ekim 2018).

11 <http://katalog.marmara.edu.tr/yordambt/yordam.php> "Hak dini”, 160; "Hamdi Yazır" 192 ve "Elmalılı" 182 sonuç içerisinden (erişim: 14 Kasım 2018).

$12<$ https://hollis.harvard.edu/primo-explore/search?vid=HVD2\&sortby=rank\&lang=en_US > "Hak dini", 50; "Hamdi Yazır" 77 ve "Elmalılı" 92 sonuç içerisinden (erişim: 29 Ekim 2018).

13 < https://en.pisai.it/library/library-assets/catalogue/> "Hak dini", 2; "Hamdi Yazır" 2 ve "Elmalılı" 2 sonuç içerisinden (erişim: 27 Ekim 2018).

14 <http://www.soas.ac.uk/library/> "Hak dini”, 3; "Hamdi Yazır" 2 ve "Elmalıll” 2 sonuç içerisinden (erişim: 29 Ekim 2018).

15 http://staatsbibliothek-berlin.de/> "Hak dini", 50; "Hamdi Yazır" 77 ve "Elmalılı" 818 sonuç içerisinden (erişim: 29 Ekim 2018).

$16<$ http://www.oxlit.co.uk/> sonuç yok (erişim: 29 Ekim 2018).

17 <http://www.jstor.org/> "Hak dini", 9; "Hamdi Yazir" 16 ve "Elmalili” 15 sonuç içerisinden (erişim: 29 Ekim 2018).

${ }_{18}<\mathrm{http}: / /$ www.mku.edu.tr/departments.aspx?birim=83>;<http://katalog.ankara.edu.tr/uhtbin/cgisirsi/?ps=VSenB9Hwkw/MA IN/45890107/123> (erişim: 29 Ekim 2018).

19 >http://platform.almanhal.com/> adresinden “" aramalarında Elmal111 ve eserinden yapılan alıntı sonuçlarına rastlansa da herhangi bir eser veya araştırmaya ulaşılamamıştır. (erişim: 29 Ekim 2018).

${ }^{20}$ Mustafa Özel, "Hak Dini Kur'ân Dili Üzerine Yapılan Akademik Çalışmalar", İslâmî Araştırmalar Dergisi, cilt: XIV, sayı: 1, ss. 145-149, Ankara 2001.
} 
Yapılmış Çalışmalar Bibliyografyası"”21 ve Kâmil Büyüker'in "Elmalılı Hamdi Yazır Bibliyografyası"22 adlı araştırmalarının yanı sıra ve ilgili literatür alanında yapılan diğer çalışmalar incelenmiştir.

\section{A. Elmalıı Üzerinde Yapılan Literatür Çalışmaları}

Elmalıı M. Hamdi Yazır ve eserleri üzerinde yapılan literatür çalışmaları iki ayrı başlık altında incelenecek düzeydedir. Bunlardan ilki araştırma konumuza benzerliğiyle öne çıan; Elmalılı üzerine yapılan çalışmaları konu edinen çalışmalardır. İkincisi ise Türkiye'deki telif ve tercüme matbu Türkçe tefsirler ve meâller üzerine yapılan bibliyografya çalışmalarıdır. Bu araştırmaların büyük bir kısmını Elmalılı tefsiri ve meâliyle bu tefsir ve meâlin sadeleştirmelerinin oluşturduğu görülmektedir. Yapılan araştırmayla olan benzerliği açısından birinci bölümde yer alan çalışmalar ilk olarak incelenecektir.

Elmalılı M. Hamdi Yazır ve Hak Dini Kur'an Dili Üzerine Yapılan Bibliyografya Çalışmaları;

1. Mustafa Özel'in "Hak Dini Kur’ân Dili Üzerine Yapılan Akademik Çalışmalar”, İslâmî Araştırmalar Dergisi, cilt: XIV, sayı: 1, ss. 145-149, Ankara 2001.

2. İshak Özgel'in "Elmalılı Muhammed Hamdi Yazır'ın Tefsiri ve Hakkında Yapılmış Çalışmalar Bibliyografyası", Türkiye Araştırmaları Literatür Dergisi, cilt: X, sayı: 19-20, ss. 327-362, İstanbul 2012.

3. Kâmil Büyüker'in "Elmalılı Hamdi Yazır Bibliyografyası” Büyük Kur'an Mütefekkiri Elmalılı M. Hamdi Yazır, DİB Yayınları, ss. 587-615, Ankara 2017, 615s.

Bu çalışmaların; konu kapsam ve sınırları açısından farklılıkları, çalışmalarda eksik bırakılan yönlerin değerlendirilmesi, öncesinde aynı alanda bir yayın varken yeniden bir araştırma yapılmasının bir tekrar olup olmadığını göstermesi açısından önemlidir. Bu sebeple ilgili araştırmalar kısaca ele alınıp tanitılacaktır.

Elmalı1ı'ya dair literatür çalışmalarının ilki olma niteliğine sahip “Hak Dini Kur’ân Dili Üzerine Yapılan Akademik Çalışmalar" adlı araştırmada isminden de anlaşılacağı üzere akademik olarak tavsif edilmeyen çalışmalar kapsam dışında bırakılmıştır. Doktora tezinde bir bölüm (1999: 1-7) olarak ele aldığ 1 bu konuyu Mustafa Özel, 2001 tarihinde makaleleştirerek yayımlamıştır. Özel bu çalışmasında; üç doktora ve on yüksek lisans tezini tanıtmış, ayrıca tamamlanmış ve devam eden birer yüksek lisans tezinin ve sunulmuş iki sempozyum tebliğinin isimlerine çalışmasında yer vermiştir. Özel'in elde ettiği verileri sonuç bölümünde değerlendirdiği ve bazı çıkarımlara ulaştığı görülür.

İshak Özgel'in "Elmalı1ı Muhammed Hamdi Yazır'ın Tefsiri ve Hakkında Yapılmış Çalışmalar Bibliyografyası" isimli çalışması, 2015 yılına kadar olan yayınların aktarıldığı bir araştırma olup iki bölümden oluşmaktadır. Birinci bölümde Elmalılı ve tefsiri ayrıntılı bir şekilde tanıtılmıştır. İkinci bölümde ise Elmalılı ve tefsiri hakkında yapılmış çalışmalar liste halinde aktarılmıştır. Özgel'in bu araştırmasında; 40'1 makale, 57'si sempozyum bildirisi, 8'i kitap ve 95'i yüksek lisans ve doktora tezi olmak üzere toplam 200 çalışmaya ulaşılmıştır (Özgel, 2012: 348). Yapılan araştırmalarda ise tarih itibariyle Özgel'in ulaşabileceği 100'ü aşkın eserin bu tasniflerde yer almadığı görülmüştür. Ayrıca Özgel, bu literatür incelemesine Elmalılı üzerine yapılan bitirme tezleriyle (biri hariç) tefsir ve meâl sadeleştirmelerini dahil etmemiştir.

\footnotetext{
${ }^{21}$ İshak Özgel, "Elmalılı Muhammed Hamdi Yazır'ın Tefsiri ve Hakkında Yapılmış Çalışmalar Bibliyografyası”, Türkiye Araştırmaları Literatür Dergisi, cilt: X, say1: 19-20, ss. 327-362, İstanbul 2012.

${ }^{22}$ Kâmil Büyüker, "Elmalılı Hamdi Yazır Bibliyografyası” Büyük Kur'an Mütefekkiri Elmalılı M. Hamdi Yazır, DİB Yayınları, ss. 587-615, Ankara 2017, 615s.
} 
Kâmil Büyüker'in 2017 tarihli "Elmalılı Hamdi Yazır Bibliyografyası” isimli çalışmasında Elmalılı'ya dair literatür araştırmalarının yanı sıra Elmalılı'nın eserlerine ait bir bibliyografya da sunulur. Bu çalışmada 10 kitap, 4 doktora, 52 yüksek lisans tezi, 108 makale ve 47 sempozyum bildirisi yer almaktadır. Yapılan araştırmalarda ise tarih itibariyle Büyüker'in makaleler açısından hemen hemen eserlerin tamamına erişirken yüksek lisans ve doktora tezi, kitap çalışması ve sempozyum bildirisi kategorilerine dahil ulaşabileceği 200'e yakın eserin bu tasniflerde yer almadığı görülmüştür. Büyüker, literatür incelemesine Elmalılı üzerine yapılan bitirme tezleriyle devam eden doktora ve yüksek lisans tezlerini ayrıca tefsir ve meâl sadeleştirmelerini dahil etmemiştir. Bu çalışmada değerlendirme bölümü bulunmamaktadır.

Araştırmamıza benzerliğiyle öne çıkan bu çalışmalar değerlendirildikten sonra Elmalılı tefsiri ve meâliyle, bu tefsir ve meâlin sadeleştirmelerine değinen ve konumuzla kısmen ilgili olan araştırmaların da tanıtılması gerekmektedir.

Türkiye'deki Telif ve Tercüme Matbu Türkçe Tefsirler ve Meâller Üzerine Yapılan Bibliyografya Çalışmaları

1. Hidayet Aydar'ın, “Türklerde Kur'an Çalışmaları”, İstanbul Üniversitesi İlahiyat Fakültesi Dergisi, say1: 1, ss. 159-235, İstanbul 1999.

2. Mustafa Öztürk'ün, “II. Meşrutiyet’ten Günümüze Kur'an Meâlleri’, Türkiye Araştırmaları Literatür Dergisi, cilt: IX, say1: 18, ss. 139-189, İstanbul 2011.

3. M. Suat Mertoğlu'nun, “Osmanlı ve Cumhuriyet Dönemi Kur'an ve Tefsir Literatürüne Toplu Bir Bakış -Birincil Eserler ve Onlara Dair İncelemeler-”, Türkiye Araştırmaları Literatür Dergisi, cilt: IX, say1: 18, ss. 9-66, İstanbul 2011.

4. Muhammet Abay'ın, “Türkçedeki Kur'an Meâllerinin Tarihi ve Kronolojik Bibliyografyası", Türkiye Araştırmaları Literatür Dergisi, cilt: X, sayı: 19-20, ss. 231-301, İstanbul 2012.

5. Hikmet Koçyiğit'in, “1980-2017 Arası Telif ve Tercüme Matbu Türkçe Tefsirler Bibliyografyası”, Karadeniz Teknik Üniversitesi İlahiyat Fakültesi Dergisi, cilt: IV, sayı: 2, ss. 9-52, Trabzon 2017.

6. Hikmet Koçyiğit'in, “Günümüz Türkçe Kur'an Meâlleri Üzerine Bir Tasnif Denemesi,” İstanbul Üniversitesi İlahiyat Fakültesi Dergisi, say1: 37, ss. 79- 121, (Aralık) İstanbul 2017.

$\mathrm{Bu}$ başlıkta yer verilen çalışmaların yanı sıra literatürde bu alanda yapılmış pek çok araştırmaya rastlanmaktadır. ${ }^{23}$ Değerlendirmeye aldığımız bu çalışmalarda ise ya Elmalılı ve üzerinde oluşan literatüre daha fazla yer verildiği veyahut da mezkûr çalışmaların yürütülen araştırmaya birincil kaynak olarak kullanılabileceği yargısını zihinde oluşturacak bir isimlendirmeye sahip olduğu görülür. Türkiye'de yapılan tefsir ve meâllerin incelendiği bu çalışmalar, araştırmamızın "Hak Dini Kur'an Dili Tefsirine Dair Sadeleştirme Çalışmaları" ve "Hak Dini Kur'an Dili Tefsirinden Elde Edilen Meâller ve Sadeleştirme Çalışmaları" adlı bölümleri açısından önem arz etmektedir. Çünkü bu çalışmaların büyük bir kısmını Elmalılı tefsiri ve meâliyle bu tefsir ve meâlin sadeleştirmelerinin oluşturduğu görülmektedir. Mezkûr alandaki çalışmalar değerlendirildiğinde;

Hidayet Aydar'ın, "Türklerde Kur'an Çalışmaları" isimli araştırmasında; hem Elmalılı'nın tefsiri ve bu tefsirden elde edilen meâli tanıtılmış hem de 1999 yılına kadar yayımlanan biri tefsir diğer dördü meâl olmak üzere beş sadeleştirme çalışmasına değinilmiştir. Ayrıca Türkiye'deki Kur'ân çalışmaları içerisinde bu faaliyetlerin yerini belirleyen değerlendirmelerde bulunulmuştur.

\footnotetext{
${ }^{23}$ İlgili eserler için bkz. (Abay, 2012: 231-232; Koçyiğit, 2017: 12-13).
} 
Mustafa Öztürk’ün, “II. Meşrutiyet’ten Günümüze Kur’an Meâlleri” adlı çalışmasında Elmalılı'nın tefsirinden elde edilen meâlin dünü bugünü ve Türkiye'de kendisi sonrasında yazılan meâller üzerindeki etkisi ayrıntılı bir şekilde anlatılmıştır. Buna rağmen Elmalılı tefsiri ve meâli üzerine yapılan sadeleştirmeler bir liste halinde verilmemiştir.

M. Suat Mertoğlu'nun, “Osmanlı ve Cumhuriyet Dönemi Kur'an ve Tefsir Literatürüne Toplu Bir Bakış -Birincil Eserler ve Onlara Dair İncelemeler-" isimli çalışmasında Osmanlı ve Cumhuriyet Dönemi Kur'an ve tefsir literatürünün tamamına ait genel bir fotoğrafın sunulması amaçlanmaktadır. $\mathrm{Bu}$ sebeple Elmalılı tefsiri ve meâli üzerine yapılan sadeleştirmelere dair bir liste oluşturma amacı güdülmemiş, Muhammet Abay'ın çalışmasında Elmalılı'nın ve diğer müelliflerin meâline dair 51 sadeleştirme çalışmasına ulaşıldığı bilgisine yer verilmekle yetinilmiştir.

Muhammet Abay'ın, "Türkçedeki Kur'an Meâllerinin Tarihi ve Kronolojik Bibliyografyası" adlı çalışmasıyla araştırmamızın "Hak Dini Kur'an Dili Tefsirine Dair Sadeleştirme Çalışmaları" ve "Hak Dini Kur'an Dili Tefsirinden Elde Edilen Meâller ve Sadeleştirme Çalışmaları" bölümünün hem sistem hem de konuyu ele alış tarzının benzeştiği söylenebilir. Titiz bir çalışma ve taramanın ürünü olarak nitelendirilebilecek Abay'ın araştırmasında ilgili bölümde farklı eserlere ait sadeleştirme ürünü olan 49 meâl çalışması aktarılır. Bunların 47'si Elmalılı tefsiri üzerinden elde edilen meâllerdir. Bu çalışmada tefsir üzerine yapılan sadeleştirmelerden beşine yer verilmiştir. Bu bölümler dışında da Elmalılı'ya dair çalışmaları aktaran mezkûr araştırmada tarih itibariyle Abay'ın ulaşabileceği 20 eserin verilen tasniflerde yer almadığ 1 görülmüştür.

Hikmet Koçyiğit'in "Günümüz Türkçe Kur'an Meâlleri Üzerine Bir Tasnif Denemesi” adlı araştırmasında Elmalılı meâli; "Nüzul Sırasına Göre Meâller", "Tefsirin Parçası Olarak Yazılan Meâller", "Sadeleştirilmiş Meâller", "Kopya Meâller", "Promosyon/Hediye Meâller" ve "Gül Kokulu Meâller" ${ }^{24}$ başlıkları altında incelenmiş ve birer ikişer aktarımla örneklendirilmiştir. Söz konusu meâllere dair toplu bir liste yer almamaktadır.

Hikmet Koçyiğit'in, "1980-2017 Arası Telif ve Tercüme Matbu Türkçe Tefsirler Bibliyografyası" isimli çalışmasında "sadeleştirme ve hazırlama nev'inden bazı çalışmaları tercüme kapsamında değerlendireceğiz" şeklinde bir sınıflandırma yapılmasına rağmen araştırmada, Elmalılı tefsiri üzerine yapılan sadeleştirme çalışmalarına yer verilmemiştir. "Türkçe Telif Edilmiş Kısmî Tefsirler" bölümünde ise Elmalılı üzerine yapılan bir eser yer almaktadır.

Elmalılı M. Hamdi Yazır ve eserleri üzerinde yapılan literatür çalışmalarının yayımlandıkları yıl göz önünde bulundurulsa da hem bu araştırmaların kapsamlarının farklı olarak tayin edilmesi hem de bu araştırmalarda birçok eserin yer almadığının belirlenmesi, yeni ve gelişen imkanlar dahilinde literatürü en kapsamlı bir şekilde yansıtan bir diğer araştırmanın yapılmasını gerekli kılmıştır.

Elmalılı ve eserleri üzerine yapılan çalışmalar; kitap çalışmaları, kitap bölümleri, sadeleştirmeler, tezler, makaleler, sempozyum bildirileri ve ansiklopedi maddeleri başlıklarında ele alınacaktır. Mezkûr başlıklar altında ise ilgili eserler yayımlanma kronolojisine göre sıralanacaktır.

\footnotetext{
${ }^{24}$ Gül, Hz. Peygamberi simgelediği için bazı meâl kitaplarına gül kokusu katılmıştır (Koçyiğit, 2017:115). Bu tasnif Türkiye'de meâllere dair yayıncılığın ve sembolik din algısınının ulaştığı noktayı göstermesi açısından önemlidir.
} 


\section{B. Elmalıı M. Hamdi Yazır ve Eserleri Üzerine Yazılmış Kitaplar ve Kitap Bölümleri}

\section{Elmalıı M. Hamdi Yazır ve Eserleriyle İlgili Yazılmış Kitaplar}

\section{1 Özgün Kitap Çalışmaları}

1. Hak Dini Kur'an Dili Fihristi ve Lügati, Hazırlayanlar: Suat Yıldırım, Asım Uysal, Kadir Kesici, Kamil Uzun, Mustafa Köseoğlu, Durali Yılmaz ve Cahit Baltacı, Eser Neşriyat ve Dağıtım, İstanbul 1982, 702s.

2. Peygamber Efendimiz ve Ashab-ı Kiram'ın Hayatlarından Seçilmiş Dini Hikâyeler: Elmalılı Tefsiri'nin Nakillerine Göre, Eser Neşriyat, İstanbul 1983, 284s.

3. Elmalılı Muhammed Hamdi Yazır, TDV Yayınları, Ankara 1993, 338s. ${ }^{25}$

4. Orhan Kuntman, Elmalılı ve Diğer Müfessirlerin Işı̆̆ında Kur'ân-ı Kerîm'in Özet Açılklaması ve Huruf-u Mukattaa ile Bazı Ayetlerin Bilimsel Yorumu, Kariyer Matbaas1, Ankara 1997, 724s.

5. Şadi Eren, Elmalılı Hamdi Yazır'dan Tefsir Nükteleri, Zafer Yayınları, İstanbul 1998, $112 \mathrm{~s}$.

6. Mehmet Yaşar Soyalan, Elmalılı Tefsirinde Kur'ânî Terimler ve Deyimler, Ağaç Yayınları, İstanbul 2003, 360s.

7. Mehmet Türkeri, Elmalılı'nın Ahlak Felsefesi, İzmir İlâhiyat Vakfı Yayınları, İzmir 2006, $166 \mathrm{~s} .{ }^{26}$

8. Faruk Yaslıçimen-Mustafa Özel, Elmalılı Muhammed Hamdi Yazır, İLEM (İlmî Etüdler Derneği) Yayınları, İstanbul 2008, 16s. ${ }^{27}$

9. İshak Özgel, Kur'ân'ın Türkçe'ye Tercümesinde Söz Dăgarcı̆̆ı (M. Hamdi Yazır Meâli'nde A ̌̆ızlardan İstifade Örneği), İdeal Ajans, Isparta 2008.

10. Abdullah Çolak, Elmalılı M. Hamdi Yazır ve Hukukçuluğu (Hak Dini Kur'an Dili Bağlamında), Malatya 2011.

11. Abdullah Çolak, Elmalılı M. Hamdi Yazır'ın Bazı Görüşleri, Elmalı Belediyesi, Elmalı/Antalya 2012.

12. Necmi Atik, Hattat Elmalılı Muhammed Hamdi Yazır: Hayatı ve Eserleri, Antalya 2013, $96 \mathrm{~s}$.

13. Benjamin Flöhr, Ein traditionalistischer Korandeuter im Dienste des Kemalismus: Elmalili Muhammed Hamdi Yazir (1878-1942), Klaus Schwarz Verlag/(Islamkundliche Untersuchungen; Bd. 326.) Berlin, 2015, 561s.

14. Elmalılı Muhammed Hamdi Yazır Sempozyumu, Antalya 2012, (Editörler: Ahmet Ögke-Rıfat Atay), TDV Yayınları, Ankara 2015, 710s.

15. Büyük Kur'an Mütefekkiri Elmalılı M. Hamdi Yazır, Diyanet İşleri Başkanlığı Yayınları, Ankara 2017, 615s.

16. Asım Cüneyd Köksal, Elmalılı M. Hamdi Yazır, İlke Yayınc1lık, İstanbul 2017, 150s.

17. İbrahim Kaya, Elmalılı Tefsiri Üzerine Bazı Mülâhazalar, STS Yayınları, Rize 2018, 306s.

\subsection{Makale ve Tezlerden Üretilmiş Kitaplar}

1. Mehmet Şirin Ayiş, Elmalılı Tefsirinde Tasavvuf, Rağbet Yayınları, İstanbul 2015, 312s.

\footnotetext{
25 4-6 Eylül 1991'de Antalya/Elmalı'da yapılan Elmalılı Muhammed Hamdi Yazır Sempozyumu'nun bildirilerini ihtiva eden eserdir.

${ }^{26}$ Ayrıca Lotus Yayınları, İstanbul 2013, 166 sayfa olarak yayımlanmıştır.

${ }^{27}$ İLEM (İlmî Etüdler Derneği)'nin 31 Mayıs 2008'de İstanbul'da yaptığı anma toplantısının kitapçı̆̆ı olarak basılmıştır.
} 
2. Mehmet Kurt, Elmalılı Tefsirinde Mucize-Bilim İlişkisi, Hikmetevi Yayınları, İstanbul 2017, 152s.

3. Serkan Ünal, Elmalılı Muhammed Hamdi Yazır ve Tenkitçi Yönü: İbn Sinâ ve Muhammed Abduh Örneği, Kökler Derneği Yayınları, İstanbul 2017, 142s.

\subsection{Kitap Bölümleri}

1. İbnülemin Mahmut Kemal İnal, "Hamdi Efendi” Son Hattatlar, Maarif Matbaası, İstanbul 1955, ss, 107-110, 827s.

2. Ömer Nasuhi Bilmen, "Elmalılı Muhammed Hamdi Efendi”, Büyük Tefsir Tarihi (Tabakâtü’lMüfesssirîn, Diyanet İşleri Reisliği Yayınları, Ankara 1960, ss. 607-615, 724s.

3. Ebü'l-Ula Mardin, "Elmalılı Muhammed Hamdi Efendi”, Huzûr Dersleri, İstanbul Üniversitesi Hukuk Fakültesi İsmail Akgün Matbaası, İstanbul 1966, 1c'de 2-3. c. ss. 241-247. 1113s.

4. Sadık Albayrak, "Mehmet Hamdi (Yazır) Efendi (Elmal111)" Son Devir Osmanlı Ulemast: (İlmiye Ricalinin Teracim-i Ahvali), Medrese Yayınevi, İstanbul 1980, cilt: III, s. 171, 336s.

5. Vehbi Vakkasoğlu, "Elmalılı Mehmet Hamdi Yazır (1878-1942)”, Osmanlıdan Cumhuriyete İslam Âlimleri, Cihan Yayınları, ss. 9-30, İstanbul 1987, 192s.

6. Dücane Cündioğlu, "Elmalılı Tefsiri'nin Yazma Nüshası", ss. 138-146; "Elmalıl1”" Sadeleştirmelerinin Sefaleti”, ss. 146-156, Kur'an Çevirilerinin Dünyası, Kaknüs Yayınları, İstanbul 2005, 264s.

7. İsmail Kara, "Elmal1lı Hamdi Efendi ve Halifelik", Türkiye'de İslamcllı Düşüncesi, Dergah Yayınları, ss. 463-513, İstanbul 2011, 1174s.

8. Ursula Ragacs, "Elmalıl1 (1878-1942)" Religion übersetzen: Übersetzung und Textrezeption als transformation sphänomene von Religion, Grohmann, Marianne; Appel, Kurt; Danz, Christian; Potz, Richard; Rosenberger, Sieglinde; Walser, Angelika vd. Gottingen: Vandenhoeck \& Ruprecht 2012, ss. 212-213.

9. Mustafa Öztürk, “Elmalılı'nın Hak Dini Kur'an Dili Tefsirinin Mukaddimesi”, Osmanlı Tefsir Mirası, Ankara Okulu Yayınları, ss. 193-197, Ankara 2012, 240s.

10. Mehmet Murat Çekmen, “Elmalılı M. Hamdi Yazır'da Kişilik Oluşumu”, Bilimsel Kişilik Oluşumu ve Nefsin Terbiyesi, Editör: Ahmet Ögke, ss. 33-49, Antalya 2013, 222s.

11. Ahmet Şeyhun, "Chapter 13 Elmalili Hamdi Yazir (1878-1942)" Islamist Thinkers in the Late Ottoman Empire and Early Turkish Republic, Leiden/Netherlands, Brill, 2014. ss. 172-184, 203s.

12. M. Brett Wilson, Translating the Qur'an in an Age of Nationalism: Print Culture and Modern Islam in Turkey, Oxford University Press, in association with the Institute of Ismaili Studies London 2014, ss. 55-184.

13. İsmail Albayrak, "Elmalı'lı Muhammed Hamdi Yazır ve Hak Dini Kur'ân Dili Adlı Tefsiri (İstanbul Alimi Örneği)" Klasik Modernizmde Kur'ân'a Yaklaşımlar, Ensar Neşriyat, ss. 137-202, İstanbul 2014, 256s.

14. Benjamin Flöhr, "Die Vita Elmalili Muhammed Hamdi Yazors (1878-1942)", Junge Perspektiven der Türkeiforschung in Deutschland, Springer VS, Wiesbade 2014, ss. 61-78.

15. İsmail Albayrak "A Turkish Exegesis of the Early Twentieth Century: Elmalili Muhammad Hamdi Yazır (d. 1942) and his Hak Dini Kur'an Dili" The Qur'an and its readers worldwide: contemporary commentaries and translations, New York, Oxford University Press in association with The Institute of Ismaili Studies / Qur'anic studies series 14, London 2015, ss. 633s. 
16. Susan Gunasti, "Philosophy as Methodology: Elmal11 Muhammed Hamdi Yazır's Spiritualism and Religious Reform in the Late Ottoman Empire", Refonners and Intellectual Refonnulationin Contemporary Islam (29-30 January), London 2015.

17. Mesut Okumuş, "Elmalılı Muhammed Hamdi Yazır'ın Hayatı İlmî Kişiliği ve Eserleri”, Büyük Kur'an Mütefekkiri Elmalılı M. Hamdi Yazır, DİB Yayınları, ss. 7-32, Ankara 2017, 615s.

18. Mehmet Ünal, "Hak Dini Kur'ân Dili'nde Kırâatlerin Ele Alınış Tarzı”, Büyük Kur'an Mütefekkiri Elmalılı M. Hamdi Yazır, DİB Yayınları, ss. 139-176, Ankara 2017, 615s.

19. Mahmut Öztürk, “Kelime Bağlamında Elmalılı Meâli’nin Bazı Özellikleri”, Büyük Kur'an Mütefekkiri Elmalılı M. Hamdi Yazır, DİB Yayınları, ss. 177-241, Ankara 2017, 615s.

20. Ejder Okumuş, “Hak Dini Kur'ân Dili’nde Sosyolojik İmalar”, Büyük Kur'an Mütefekkiri Elmalılı M. Hamdi Yazır, DİB Yayınları, ss. 359-414, Ankara 2017, 615s.

21. Merter Rahmi Telkenaroğlu, "Gelenek ve Modernite Arasında Elmalılı'nın Tecdit Anlayışı”, Büyük Kur'an Mütefekkiri Elmalılı M. Hamdi Yazır, DİB Yayınları, ss. 497-516, Ankara 2017, 615s.

22. Şerafettin Severcan, "Elmalılı M. Hamdi Yazır'ın Muhalif Kimliği ve Tefsirinin Yazılış Süreci”, Büyük Kur'an Mütefekkiri Elmalılı M. Hamdi Yazır, DİB Yayınları, ss. 517-549, Ankara 2017, 615s.

23. İsmail Çalışkan, "Elmalılı Hamdi Yazır M. Abduh'a Neden Kızdı? Bilgi Çağında Bir Bilgin Müfessirin Bilimsel Tefsir Nosyonu", Büyük Kur'an Mütefekkiri Elmalllı M. Hamdi Yazır, DİB Yayınları, ss. 551-585, Ankara 2017, 615s.

24. Kâmil Büyüker, "Elmalılı Hamdi Yazır Bibliyografyası” Büyük Kur'an Mütefekkiri Elmalılı M. Hamdi Yazır, DİB Yayınları, ss. 587-615, Ankara 2017, 615s.

\subsection{Sempozyum Kitap Bölümleri}

1. Fatma Paksüt, "Merhum Dayım Hamdi Yazır", Elmalılı Muhammed Hamdi Yazır, TDV Yayınları, ss. 2-24, Ankara 1993, 338s. ${ }^{28}$

2. Nesimi Yazıcı, "Muhammed Hamdi Yazır'ın Basın Hayatı ve Yazarlı̆̆ı”, Hamdi Yazır”, Elmalılı Muhammed Hamdi Yazır, TDV Yayınları, ss. 25-32, Ankara 1993, 338s.

3. Ali Yılmaz, "Elmalılı Hamdi Yazır'ın Türkçesi”, Hamdi Yazır”, Elmalılı Muhammed Hamdi Yazır, TDV Yayınları, ss. 33-44, Ankara 1993, 338s.

4. Mehmet Emin (Erişirgil), "İki Eser-i Felsefi Münasebetiyle”, Sadeleştiren: Recep Kılıç, Elmalılı Muhammed Hamdi Yazır, TDV Yayınları, ss. 45-48, Ankara 1993, 338s.

5. Recep Kılıç, "Elmalılı Muhammed Hamdi Yazır”, "Dibace (Önsöz)”, (Sadeleştirme), Elmalılı Muhammed Hamdi Yazır, TDV Yayınları, ss. 49-123, Ankara 1993, 338s.

6. Süleyman Hayri Bolay, "Bir Filozof Müfessir", Elmalılı Muhammed Hamdi Yazır, TDV Yayınları, ss.125-139, Ankara 1993, 338s. ${ }^{29}$

7. Hasan Onat, "Elmalılı Hamdi Yazır'ın Anlayışı ve Mezheplere Bakışı", Elmalılı Muhammed Hamdi Yazır, TDV Yayınlar1, ss. 140-151, Ankara 1993, 338s.

\footnotetext{
${ }^{28}$ Bu bildiri ayrıca ("Merhum Dayım Hamdi Yazır I”, Altınoluk Dergisi, sayı: 74, ss. 20-23, İstanbul 1992), "Merhum Dayım Hamdi Yazır II", Altınoluk Dergisi, sayı: 75, ss. 21-22, İstanbul 1992 ve "Merhum Dayım Hamdi Yazır III", Altınoluk Dergisi, sayı: 76, ss. 42-44, İstanbul 1992'de yayımlanmıştır.

${ }_{29} \mathrm{Bu}$ bildiri daha önce "Bir Filozof Müfessir, M. Hamdi Yazır", Milli Eğitim ve Kültür Dergisi, sayı: 15, ss. 20-34, Ankara 1982'de yayımlanmıştır.
} 
8. Halis Albayrak, "Elmalıı M. Hamdi Yazır'ın Tefsir Anlayışı”, Elmalılı Muhammed Hamdi Yazır, TDV Yayınlar1, ss. 152-168, Ankara 1993, 338s.

9. İsmet Ersöz, "Elmalılı Hamdi Yazır ve Tefsirinin Özellikleri”, Elmalılı Muhammed Hamdi Yazır, TDV Yayınları, ss. 169-177, Ankara 1993, 338s.

10. İbrahim Kafi Dönmez, "Hamdi Yazır'ın Fıkıh Usûlü Anlayışı”, Elmalılı Muhammed Hamdi Yazır, TDV Yayınlar1, ss. 179-186, Ankara 1993.

11. İbrahim Çalışkan, "Muhammed Hamdi Yazır'ın Hukukçuluğu”, Elmalılı Muhammed Hamdi Yazır, TDV Yayınları, ss. 187-196, Ankara 1993, 338s.

12. Nazif Öztürk, "M. Hamdi Yazır'ın Vakıfcılık Anlayışı”, Elmalılı Muhammed Hamdi Yazır, TDV Yayınları, ss. 197-208, Ankara 1993, 338s. ${ }^{30}$

13. Tahsin Görgün, "Hamdi Yazır'ın Sosyal Felsefesine Giriş”, Elmalılı Muhammed Hamdi Yazır, TDV Yayınlar1, ss. 210-220, Ankara 1993, 338s.

14. Hüseyin Algül, "Hak Dini Kur'ân Dili Tefsirinde İslâm Tarihi Dokümanlarının Değerlendirilişi”, Elmalll Muhammed Hamdi Yazır, TDV Yayınları, ss. 221-230, Ankara 1993, 338s. ${ }^{31}$

15. Mustafa Kara, "Hak Dini Kur'ân Dili'nde Tasavvuf Kültürü Üzerine-Hiradan Viyana'ya Bir Çizgi”, Elmalılı Muhammed Hamdi Yazır, TDV Yayınları, ss. 231-240, Ankara 1993, 338s.

16. Münir Koştaş, "M. Hamdi Yazır'ın İçtimâî Görüşleri”, Elmalılı Muhammed Hamdi Yazır, TDV Yayınları, ss. 241-244, Ankara 1993, 338s.

17. Nevzat Yaşar Aşıkoğlu, “M. Hamdi Yazır’ın Terbiye Anlayışı ve Eserlerine Eğitimci Gözüyle Bir Bakış", Elmalılı Muhammed Hamdi Yazır, TDV Yayınları, ss. 245-252, Ankara 1993. ${ }^{32}$

18. İsmail Kara, "Elmalılı Hamdi Efendi ve Halifelik", Elmalılı Muhammed Hamdi Yazır, TDV Yayınlar1, ss. 253-258, Ankara 1993, 338s.

19. Hüseyin Aydın, "Bir Mütefekkir Olarak M. Hamdi Yazır”, Elmalılı Muhammed Hamdi Yazır, TDV Yayınlar1, ss. 260-264, Ankara 1993.

20. Ahmet Akbulut, "Muhammed Hamdi Yazır'da Kelâmî Problemler", Elmalılı Muhammed Hamdi Yazır, TDV Yayınları, ss. 265-280, Ankara 1993, 338s.

21. Halis Albayrak, "Elmalılı Hamdi Yazır'a Göre Kur'ân'da Din Kavramı”, Elmalılı Muhammed Hamdi Yazır, TDV Yayınlar1, ss. 281-289, Ankara 1993, 338s.

22. Recep Kılıç, "Hamdi Yazır'da Din Felsefesi”, Elmalılı Muhammed Hamdi Yazır, TDV Yayınları, ss. 290-298, Ankara 1993, 338s. ${ }^{33}$

23. Mehmet S. Aydın, "Elmalılı'da Teceddüd Fikri”, Elmalılı Muhammed Hamdi Yazır, TDV Yayınları, ss. 299-305, Ankara 1993. ${ }^{34}$

24. Tahsin Görgün, "Hamdi Yazır'ın Bilgi Teorisi”, Elmalılı Muhammed Hamdi Yazır, TDV Yayınları, ss. 306-316, Ankara 1993, 338s.

\footnotetext{
${ }^{30}$ Bu bildiri daha önce "M. Hamdi Yazır'ın Vakıfcılık Anlayışı”, İslâmî Araştırmalar Dergisi, cilt: V, sayı: 3, ss. 208-214, (Temmuz) Ankara 1991)'de yayımlanmıştır.

${ }^{31}$ Bu bildiri ayrıca Yeni Ümit Dergisi, sayı: 24, (Nisan-Haziran 1994), İzmir 1994'de yayımlanmışıtır.

${ }^{32}$ Bu bildiri ayrıca "M. Hamdi Yazır'ın Terbiye Anlayışı ve Eserlerine Eğitimci Gözüyle Bir Bakış”, Din Öğretimi Dergisi, sayı: 31, ss. 63-70, Ankara 1991)'de yayımlanmıştır.

${ }^{33} \mathrm{Bu}$ bildiri ayrıca "Hamdi Yazır'da Din Felsefesi” Türk Yurdu Dergisi, cilt: XII, sayı: 53, ss. 47-50, İstanbul 1992'de yayımlanmıştır.

${ }_{34}$ Bu bildiri ayrıca Din Öğretimi Dergisi, Ankara 1992, sayı: 34, ss. 49-54'de yayımlanmıştır.
} 
25. Hüsrev Subaşı, "Elmalılı Hamdi Efendi ve Hat Sanatımızdaki Yeri”, Elmalılı Muhammed Hamdi Yazır, TDV Yayınları, ss. 318-330, Ankara 1993. ${ }^{35}$

26. Muhsin Macit, "Elmalı1ı Hamdi Yazır'ın Bir Gazeli Etrafında", Elmalılı Muhammed Hamdi Yazır, TDV Yayınları, ss. 331-334, Ankara 1993, 338s.

27. Nazif Öztürk, "Elmalılı M. Hamdi Yazır'ın Metrukâtı Hakkında Ön Rapor”, Elmalılı Muhammed Hamdi Yazır, TDV Yayınları, ss. 335-338, Ankara 1993, 338s.

28. Beşir Gözübenli, "Elmalılı Hamdi Yazır'ın Seferilik Konusuna Yaklaşımı, Seferilik ve Hükümler”, ISAV Tartışmalı İlmi Toplantılar Dizisi, ss. 137-152, İstanbul 1997.

29. Ahmet T. Karamustafa, "Yeni Bir Din Felsefesi Arayışı ve Elmalılı Hamdi Yazır", Osmanlı Devleti'nde Din ve Vicdan Hürriyeti", Milletlerarası Tartışmalı İlmi Toplantı (Kasım 1999, Ístanbul), Ensar Neşriyat, ss. 289-295, İstanbul 2000.

30. Sabri Yılmaz, “Hak Dini Kur’ân Dili’nde Kader İnancı ve İnsan Hayatındaki Yeri”, Günümüz İnanç Problemleri Ilahiyat Fakülteleri Kelam Anabilim Dalı Sempozyumu, Erzurum 2001, Aktif Yayınları, ss. 171-178, Erzurum t.y.

31. Mustafa Akçay, "M. Esed'in "Sünnetullah, Fitratullah, Sibğatullah, Bezm-i Elest (Misak) ve Fetret" Kavramlarını Anlamlandırışı ve M. Hamdi Yazır ile Rıza Doğrul Meâlleriyle Karşılaştırılması", Kur'ân Meâlleri Sempozyumu -Eleştiriler ve Öneriler- (24-26 Nisan 2003, İzmir), Diyanet İşleri Başkanlığ Yayınları (2 cilt), cilt: I, ss. 349-384 Ankara 2007, 1040s.

32. İbrahim Hilmi Karslı, "Çeviri Kuramları Açısından M. Hamdi Yazır'ın Çeviri Yöntemi”, Kur'ân Meâlleri Sempozyumu -Eleştiriler ve Öneriler- (24-26 Nisan 2003, İzmir), Diyanet İşleri Başkanlığ Yayınlar1 (2 cilt), cilt: II, ss. 41-68, Ankara 2007, 1040s.

33. Mustafa Gündüz, "Elmalı1ı Muhammed Hamdi'nin Çağdaş Türk Düşüncesindeki Yeri ve Önemi Üzerine Bazı Düşünceler", 20. Yüzyılda Antalya Sempozyumu (22-24 Kasım 2007), Hazırlayan: Mustafa Oral, Akdeniz Üniversitesi Basımevi (2 cilt), cilt: II, ss. 621-635, Antalya 2008, 856s.

34. Sadrettin Gümüș, "Kur'an ve Tefsir'in Türkçeye Çevirisinin Tarihi Süreci”, Başlangıçtan Günümüze Türklerin Kur'an Tefsirine Hizmetleri -Tebliğler ve Müzakereler-Tartışmalı İlmi Toplantr, 21-22 Ekim 2011, ss. 25-40, Ensar Neşriyat, İstanbul 2012, 640s.

35. Murat Kaya, "Tanzimat Sonrasındaki Tefsir Faaliyetleri”, Başlangıçtan Günümüze Türklerin Kur'an Tefsirine Hizmetleri -Tebliğler ve Müzakereler-Tartışmalı İlmi Toplantı 21-22 Ekim 2011, ss. 301-338, Ensar Neşriyat, İstanbul 2012, 640s. ${ }^{36}$

36. M. Hanefi Palabıyık-Nur Gökhan-Rabia Olçar, "Elmalılı Muhammed Hamdi Yazır'ın Hz. Peygamber Algıs1, Medrese ve İlahiyat Kavşağında İslâmî İlimler", (Uluslararası Sempozyum) 29 Haziran-1 Temmuz 2012, Bingöl Üniversitesi Yayınları (2 cilt), cilt: II, ss. 319-356, Bingöl 2013.

37. Ali Kozan, "Sultan Abdülhamid'in Hal'inde Bir İslâm Âlimi: Elmalılı Hamdi Yazır", Sultan II. Abdülhamid Sempozyumu (20-21 Şubat 2014, Selanik), Türk Tarih Kurumu Yayınları (3 cilt), cilt: I, ss. 233-242, Ankara 2014, 1240s.

\footnotetext{
${ }^{35}$ Bu bildiri ayrıca "Elmalılı Hamdi Efendi ve Hat Sanatımızdaki Yeri”, İlim ve Sanat Dergisi, sayı: 33, ss. 18-26, Ankara 1992'de yayımlanmıştır.

${ }^{36}$ Bu çalışmanın başlı̆̆ında Elmalılı veya ona ait eserler açıkça belirtilmemiş olsa da araştırmanın içeriğinde Yazır'ın kendi görüşlerine ve içinde bulunduğu devre dair bilgiler bulunmaktadır.
} 
38. İsmail Kara, "Üç Dönem Üç Elmalılı Hamdi" ${ }^{37}$, Elmalılı Muhammed Hamdi Yazır Sempozyumu, Antalya 2012, (Editörler: Ahmet Ögke-Rıfat Atay), ss. 21-35, TDV Yayınları, Ankara 2015, 710s.

39. İbrahim Hilmi Karslı, "Tefsirî (Anlam Merkezli) Tercüme Açısından M. Hamdi Yazır'ın Meâl Tarzı", Elmalıl Muhammed Hamdi Yazır Sempozyumu, Antalya 2012, (Editörler: Ahmet ÖgkeRifat Atay), ss. 39-69, TDV Yayınları, Ankara 2015, 710s.

40. Veysel Güllüce, “Elmalılı M. Hamdi Yazır'ın Kevnî Ayetlere Yaklaşımı ve Bilimsel Tefsirdeki Yeri”, Elmalılı Muhammed Hamdi Yazır Sempozyumu, Antalya 2012, (Editörler: Ahmet Ögke-Rıfat Atay), ss. 71-89 TDV Yayınları, Ankara 2015, 710s.

41. İsmail Çalışkan, "Elmalı1ı Hamdi Yazır M. Abduh'a Neden Kızdı? Bilgi Çağında Bir Bilgin Müfessirin Bilimsel Tefsir Nosyonu", Elmalıl Muhammed Hamdi Yazır Sempozyumu, Antalya 2012, (Editörler: Ahmet Ögke-Rıfat Atay), ss. 91-119, TDV Yayınları, Ankara 2015, 710s. ${ }^{38}$

42. Eyüp Yaka, "Müşkil Âyetler Konusunda İbn Kuteybe-Elmalı1ı Hamdi Yazır Karşılaştırması", Elmalll Muhammed Hamdi Yazır Sempozyumu, Antalya 2012, (Editörler: Ahmet Ögke-Rifat Atay), ss. 121-176, TDV Yayınları, Ankara 2015, 710s.

43. Erdoğan Pazarbaşı, "Elmalılı Tefsirinden İşârî Yorumlar", Elmalılı Muhammed Hamdi Yazır Sempozyumu, Antalya 2012, (Editörler: Ahmet Ögke-Rifat Atay), ss. 177-186, TDV Yayınları, Ankara 2015, 710s.

44. H. Yunus Apaydın, "Elmalılı Hamdi Yazır'da Te'vil ve Tefsir Terimleri”, Elmalıl Muhammed Hamdi Yazır Sempozyumu, Antalya 2012, (Editörler: Ahmet Ögke-Rıfat Atay), ss. 189-199, TDV Yayınlar1, Ankara 2015, 710s.

45. Abdullah Çolak, "Bir Hukukçu Olarak Elmalıı M. Hamdi Yazır" Elmalılı Muhammed Hamdi Yazır Sempozyuтu, Antalya 2012, (Editörler: Ahmet Ögke-Rifat Atay), ss. 201-229, TDV Yayınları, Ankara 2015, 710s. ${ }^{39}$

46. Abdullah Kahraman, “Elmalı1ı M. Hamdi Yazır'ın Mecelle Müdafaası”, Elmalılı Muhammed Hamdi Yazır Sempozyumu, Antalya 2012, (Editörler: Ahmet Ögke-Rıfat Atay), ss. 231-264, TDV Yayınları, Ankara 2015, 710s.

47. Merter Rahmi Telkenaroğlu, “M. Hamdi Yazır'da Reforma Karşı Tecdîd ya da Başkalaşmadan Yenileşme Tasavvuru", Elmalılı Muhammed Hamdi Yazır Sempozyumu, Antalya 2012, (Editörler: Ahmet Ögke-Rifat Atay), ss. 265-288, TDV Yayınları, Ankara 2015, 710s.

48. Şevket Topal, "Elmalılı M. Hamdi Yazır İle Aksekili Ahmed Hamdi'nin Seferîlik Hükümlerine Dair Görüşlerinin Ezmânın Tagayyürüyle Ahkâmın Tagayyürü İnkâr Edilemez Fıkıh Kaidesi Çerçevesinde Analizi”, Elmalılı Muhammed Hamdi Yazır Sempozyumu, Antalya 2012, (Editörler: Ahmet Ögke-Rifat Atay), ss. 289-308, TDV Yayınları, Ankara 2015, 710s.

49. Mahmut Çınar, “Elmalı1ı M. Hamdi Yazır'ın Nübüvvet Anlayışı”, Elmalılı Muhammed Hamdi Yazır Seтроzуити, Antalya 2012, (Editörler: Ahmet Ögke-Rifat Atay), ss. 311-322, TDV Yayınları, Ankara 2015, 710s.

\footnotetext{
${ }^{37}$ Bu bildiri, "Üç Devir Üç Hamdi Efendi” başlı̆̆ıyla Diyanet İlmî Dergi’de cilt: LI, sayı: 3, Temmuz-Ağustos-Eylül 2015, ss. 11-29'de yayımlanmıştır.

${ }^{38}$ Bu bildiri (2-4 Kasım 2012, Antalya, Elmalılı M. Hamdi Yazır Sempozyumu)'ndaki bildirinin bazı ilavelerle gözden geçirilmiş hali olup ayrıca Büyük Kur'an Mütefekkiri Elmalılı M. Hamdi Yazır (DİB Yayınları, ss. 551-585, Ankara 2017, $615 \mathrm{~s}$.) isimli eserin bölümüdür.

${ }^{39}$ Bu bildiri ayrıca "Hak Dini Kur'ân Dili Bağlamında Bir Hukukçu Olarak Elmalılı M. Hamdi Yazır=Elmalılı Hamdi Yazır as a Jurist in the Context of "Hak Dini Kuran Dili”, Diyanet İlmî Dergi (Diyanet İşleri Reisliği Yıllığı), cilt: LI, sayı: 3, ss. 131162, Ankara 2015'de yayımlanmıştır.
} 
50. Bünyamin Erul, "Hak Dîni Kur’ân Dili'nde Hz. Muhammed Tasavvuru”, Elmalılı Muhammed Hamdi Yazır Sempozyumu, Antalya 2012, (Editörler: Ahmet Ögke-Rifat Atay), 323-340. TDV Yayınları, Ankara 2015, 710s.

51. İbrahim Coşkun, "Modern Çağda Dine Yöneltilen Eleştiriler ve M. Hamdi Yazır'ın İslâm İnançlarını Savunusu", Elmalılı Muhammed Hamdi Yazır Sempozyumu, Antalya 2012, (Editörler: Ahmet Ögke-Rifat Atay), ss. 341-368, TDV Yayınları, Ankara 2015, 710s.

52. Ali Kozan, "Bir Türk-İslâm Mütefekkiri: M. Hamdi Yazır ve Siyaset Felsefesi", Elmalılı Muhammed Hamdi Yazır Sempozyumu, Antalya 2012, (Editörler: Ahmet Ögke-Rifat Atay), ss. 371391, TDV Yayınları, Ankara 2015, 710s.

53. Şefaettin Severcan, "Evrensel Hilâfetten Millî Hilâfete: Elmalıı M. Hamdi Yazır", Elmalılı Muhammed Hamdi Yazır Sempozyumu, Antalya 2012, (Editörler: Ahmet Ögke-Rifat Atay), ss. 393415, TDV Yayınları, Ankara 2015, 710s.

54. Recep Çiğdem, "Elmalı1ı Hamdi Yazır ve Sultan Abdülhamid'in Hal'i”, Elmalıl Muhammed Hamdi Yazır Sempozyumu, Antalya 2012, (Editörler: Ahmet Ögke-Rıfat Atay), ss. 417-440, TDV Yayınlar1, Ankara 2015, 710s.

55. Ahmet Murat Özel, “ Batı'nın Fikrî Meydan Okumaları Bağlamında Elmalılı M. Hamdi Yazır'da Üç Terim: Akıl, Bilgi, Felsefe", Elmalılı Muhammed Hamdi Yazır Sempozyumu, Antalya 2012, (Editörler: Ahmet Ögke-Rıfat Atay), ss. 443-468, TDV Yayınları, Ankara 2015, 710s.

56. Hatice Toksöz, "Elmalı1ı Hamdi Yazır'ın İhlâs Sûresi Tefsirinde Tanrı Tasavvuru İle İlgili Felsefî Kavramlar ve İbn Sinâ'daki Temelleri”, Elmalılı Muhammed Hamdi Yazır Sempozyumu, Antalya 2012, (Editörler: Ahmet Ögke-Rıfat Atay), ss. 469-497, TDV Yayınları, Ankara 2015, 710s.

57. Yaşar Türkben, "Elmalılı M. Hamdi Yazır'ın Ölümsüzlüğe Dair Düşüncelerinin Din Felsefesi Açısından Değerlendirilmesi”, Elmalıl Muhammed Hamdi Yazır Sempozyumu, Antalya 2012, (Editörler: Ahmet Ögke-Rıfat Atay), ss. 499-515, TDV Yayınları, Ankara 2015, 710s.

58. Fulya İbanoğlu, "Mevcudu Muhafaza Ederek Terakkî Etmek: Bir II. Meşrutiyet Münevveri Olarak Elmalılı Hamdi Efendi'de Terakkî Fikri”, Elmalılı Muhammed Hamdi Yazır Sempozyumu, Antalya 2012, (Editörler: Ahmet Ögke-Rıfat Atay), ss. 517-526, TDV Yayınları, Ankara 2015, 710s.

59. Ahmet Aras, "Elmalılı M. Hamdi Yazır'ın Hıristiyanlıkla İlgili Bilgilerinin Değerlendirilmesi”, Elmalılı Muhammed Hamdi Yazır Sempozyumu, Antalya 2012, (Editörler: Ahmet Ögke-R1fat Atay), ss. 527-544, TDV Yayınları, Ankara 2015, 710s.

60. Ramazan Şahan, "Elmalı1ı M. Hamdi Yazır'ın Edebî Kişiliği ve Girmişiz Çıkmışız Redifli Şiirinin Âyetler Işı̆̆ında Değerlendirilmesi”, Elmalılı Muhammed Hamdi Yazır Sempozyumu, Antalya 2012, (Editörler: Ahmet Ögke-Rıfat Atay), ss. 547-606, TDV Yayınları, Ankara 2015, 710s.

61. Necmi Atik, "Elmalıı M. Hamdi Yazır'ın Sanat Anlayışı ve Hattatlı̆̆ı", Elmalılı Muhammed Hamdi Yazır Sempozyumu, Antalya 2012, (Editörler: Ahmet Ögke-Rıfat Atay), ss. 607-630, TDV Yayınlar1, Ankara 2015, 710s.

62. Mehmet Eren, "Elmalılı'nın Huccetullâhi'l-Bâliğa'dan Tercüme Ettiği Yazı Üzerine Bazı Mülahazalar", ss. Elmalılı Muhammed Hamdi Yazır Sempozyumu, Antalya 2012, (Editörler: Ahmet Ögke-Rifat Atay), 633-650, TDV Yayınları, Ankara 2015, 710s. ${ }^{40}$

\footnotetext{
${ }^{40} \mathrm{Bu}$ bildiri sempozyumda bildiri olarak sunulmamış ancak sempozyum kitabına alınmıştır.
} 
63. Veli Atmaca, "Elmalı1ı Tefsiri’nde Mevzû Sayılan Rivâyetler ve Mevzû Hadis Meselesine Dair Bazı Mülahazalar" Elmalılı Muhammed Hamdi Yazır Sempozyumu, Antalya 2012, (Editörler: Ahmet Ögke-Rıfat Atay), ss. 651-693, TDV Yayınları, Ankara 2015, 710s. ${ }^{41}$

64. Ali Kürşat Turgut, "Elmalılı M. Hamdi Yazır'ın Nefs-Ruh Hakkındaki Görüşleri” Elmalılı Muhammed Hamdi Yazır Sempozyumu, Antalya 2012, (Editörler: Ahmet Ögke-Rifat Atay), ss. 695710, TDV Yayınları, Ankara 2015, 710s. ${ }^{42}$

65. Muhittin Akgül, “Anlaşılır Olması Açısından M.Akif Ersoy'un Meali ve Elmalı'yla Mukayesesi”, Direnen Meal Akif Meali Editör: Recep Şentürk, Yayına Hazırlayan: Vahdettin Işık. ss. 137-160, Mahya Yayınları, İstanbul 2016, 220s. ${ }^{43}$

66. Bilal Deliser, "Hak Dini Kur'an Dili’nde İsa-Mesih ve Mehdilikle İlgili Görüşler”, Uluslararası Mehdilik Sempozyumu Bildirileri, Editörler: Mehmet Tıraşcı, Hasan Özalp, Maruf Çakır, ss. $305-$ 334, Cumhuriyet Üniversitesi Basımevi, Sivas 2018, 652s.

67. Recep Bilgin, "Hak Dini Kur'an Dili Tefsirinin Hadis Kaynakları", 10. Uluslararası Sosyal Bilimler ve Spor Kongresi, Hatay (23-25 Kasım 2018), ss. 615-623, (23-25 Kasim 2018), Rize 2018.

68. Recep Bilgin, "Bir Literatür İncelemesi; Elmalı11 M. Hamdi Yazır (1878-1942) ve Hak Dini Kur'an Dili Adlı Tefsiri Hakkında Hadis Alanında Yapılan Çalışmalar", 10. Uluslararası Sosyal Bilimler ve Spor Kongresi, Hatay (23-25 Kasım 2018), ss. 541-545, Rize 2018.

\section{Elmalıı M. Hamdi Yazır’ın Eserlerinden Üretilmiş Kitap Çalışmaları}

\subsection{Genel}

1. Elmalıı M. Hamdi Yazır, Kur'an-ı Kerim ve Meâli, Hazırlayan: Dücane Cündioğlu, İslamoğlu Yayınevi, İstanbul 1993, 604s. ${ }^{44}$

2. Nazif Öztürk, Elmalılı Muhammed Hamdi Yazır Gözüyle Vakıflar (Ahkâmü’l-Evkaf), TDV Yayınları, Ankara 1995, 515s.

3. Elmalılı M. Hamdi Yazır, Alfabetik İslâm Hukuku ve Fıkıh Istılahları Kamusu, I-V, Yayına Hazırlayan: Sitkı Gülle, Eser Neşriyat ve Dağıtım, İstanbul 1997, 2695s.

4. Elmalı1ı M. Hamdi Yazır, Makaleler I, Hazırlayanlar: Asım Cüneyd Köksal-Murat Kaya, Kitabevi, İstanbul 1997, 333s.

5. Elmalı1ı M. Hamdi Yazır, Hak Dini Kur'an Dili Tefsiri, Tebyiz; Mahmud Bedreddin Yazır, Asitane Yayınlar1, İstanbul 1998, (9 Cilt). ${ }^{45}$

\footnotetext{
${ }^{41} \mathrm{Bu}$ bildiri sempozyumda bildiri olarak sunulmamış ancak sempozyum kitabına alınan bildiridir.

${ }^{42} \mathrm{Bu}$ bildiri sempozyumda bildiri olarak sunulmamış ancak sempozyum kitabına alınmıştır.

43 İstanbul'da 6-7 Nisan 2013 tarihlerinde "Direnen Meal Akif Meali Uluslararası Sempozyum" adıyla düzenlenen sempozyumun kitap olarak yayımlanmıs halidir.

${ }^{44}$ Ayrıca Murat Yayınevi, İstanbul 2001, 604s; İpek Yayın Dağıtım, İstanbul 2002, 600 sayfa olarak yayımlanmıştır. Bu neşirde sadeleştirme yapılmayıp tefsirin meâl kısmı, tefsirden alınan notlarla birlikte neşredilmiştir. (Abay, 2012: 276-277)

${ }^{45}$ Elmalılı'nın en önemli eseri kabul edilen aynı zamanda Elmalılı üzerine yapılan çalı̧̧maların birçoğunun odak noktasını oluşturan Hak Dini Kur'ân Dili, ilk olarak Diyanet İşleri Başkanlığı'nın desteğiyle 1935-1939 yılları arasında İstanbul'da Ebuzziya Matbaasında bir cildi fihrist olmak üzere, dokuz cilt ve 6433 sayfa olarak 10.000 takım basılmıştır. İki bin takımı Elmalılı M. Hamdi Yazır'a verilmiş, kalanı da ücretsiz olarak dağıtılmıştır. İkinci baskısı da yine Diyanet İşleri Başkanlığı tarafından 1960 yılında İstanbul'da Nebioğlu Basımevi'nde ofset tekniği ile, üçüncü baskısı da 1971 yılında İstanbul'da Eser Yayınevi tarafından sayfa üstlerine sûre adı, cüz ve ayet numaraları vb. ilavelerle basılmıştır. Buna ek olarak sadeleştirme yapılmadan Bedir Yayınları tarafından 1993'te 8 cilt, Yenda Yayınları tarafından 2014'te 10 cilt ve Fazilet Neşriyat tarafindan 2016'da 9 cilt olarak basılmıştır. Ayrıca Elmalılı'nın kardeşi Mahmut Bedrettin Yazır (1895-1952) tarafından 12 yıl süren bir çalışmayla 12 Şevval 1361/23 Teşrinievvel 1942'de Hak Dini Kur'ân Dili'nin müsveddelerinden tebyiz edilerek (temize çekilerek) nesih, ta'lik ve rik'a yazılarıyla üç nüsha çoğaltılmıştır (İslâm-Türk Ansiklopedisi, II, ss. 55-56). Bu Osmanlıca
} 
6. Elmalı1ı M. Hamdi Yazır, Makaleler II, Hazırlayanlar: Asım Cüneyd Köksal-Murat Kaya, Kitabevi, İstanbul 1998, 191s.

7. Elmalıı М. Hamdi Yazır, Kur'an-ı Kerim ve Meâl-i Şerifi, Hazırlayan: Ertuğrul Özalp, İşaret Yayınlar1, İstanbul 2001, 640s. ${ }^{46}$

8. Orhan Kuntman, Ayetler Arasındaki Münasebetleri Belirten Kur'an-ı Kerim, (İbn Kesir, Razi ve Elmalılı'nın Yorumları Işı̆̆ında Açıklamalı Meâl ve Ek Çalışmalar), Ufuk Matbaası, Ankara 2002, 680s.

9. Elmalı1ı M. Hamdi Yazır, İslam Düşüncesinin Problemlerine Giriş, Sadeleştiren: Recep Kılıç, TDV Yayınları, Ankara 2005, 96s.

10. Elmalılı M. Hamdi Yazır, Meşrutiyetten Cumhuriyete Makaleler (Din-Felsefe-Siyaset-Hukuk), Hazırlayanlar: Asım Cüneyd Köksal-Murat Kaya, Klasik Yayınlar, İstanbul 2011, 427s.

11. Elmalılı M. Hamdi Yazır, Osmanlı Anayasasına Dair, Derleyenler: Asım Cüneyd-Köksal, Ufuk Kitapları, İstanbul 2014, 390s.

12. Elmalı1 M. Hamdi Yazır (1878-1942), Osmanl Anayasasina Dair: Kanun-i Esasi'nin 1909 Tadiline Dair Rapor: Mehakim-i Şer'iyye ve Hükkam-ı Şer' Kanunu Esbab-ı Mucibe Mazbatası, Küre Yayınları, İstanbul 2018, 239s.

\subsection{Hak Dini Kur'an Dili Tefsirine Dair Sadeleştirme Çalışmaları}

Cumhuriyetin ilk yıllarında te'lif edilen Hak Dini Kur'ân Dili isimli tefsirin dili, zamanla insanlara ağır gelmeye başlayınca 1990'lı yıllardan önce sadeleştirme yapılması düşünülmüss, hukûkî nedenlerden dolayı bu düşünce gerçekleşememiştir. 1990'lardan sonra hukûkî engeller ortadan kalkınca tefsir üzerinde çeşitli araştırmacılar tarafından sadeleştirme çalışmaları yapılmıştır. Fakat bu çalışmalarda genel olarak eserin orijinalliği, ağırlığı ve akıcılığı kaybolmuştur. Aslında yapılması gereken, eserin orijinalliğine dokunmadan ve cümle yapısını bozmadan, gramer kurallarına uygun bir tetkik ile tekrar basmaktır.

Söz konusu bu çalışmaları şöyle sıralamak mümkündür:

1. Elmalılı M. Hamdi Yazır, Hak Dini Kur'an Dili, (9 Cilt). Sadeleştirenler: M. Nur Çetin, Taha Parlar, İdris Şen, Mesut Okumuş, Mevlüt Uyanık, Orhan Atalay, Yusuf Canpolat, Alim Gür, Çelik-Şura Yayınları, İstanbul 1992.

2. Elmalılı M. Hamdi Yazır, Hak Dini Kur'ân Dili, (10 Cilt). Sadeleştirenler: Selahattin Kaya, Cahit Baltac1, Durali Yılmaz, Kerim Aytekin, Eser Neşriyat, İstanbul 1992.

3. Elmalılı M. Hamdi Yazır, Hak Dini Kur'ân Dili, (10 Cilt). Sadeleştirenler: İsmail Karaçam-Emin Işık-Nusrettin Bolelli-Abdullah Yücel, Azim Yayınları, İstanbul 1992.

4. Elmalı1ı M. Hamdi Yazır, Hak Dini Kur'ân Dili, (10 Cilt). Sadeleştiren: Sitk1 Gülle, Tahkik: M. Sadi Çöğenli, Nevzat H. Yanık, Huzur Yayınevi, İstanbul 2003. ${ }^{47}$

5. Elmalılı M. Hamdi Yazır, Hak Dini Kur'ân Dili Elmalılı Tefsir, (10 Cilt). Sadeleştiren: Kasım Yayla, Merve Yayınları, İstanbul 2012.

\footnotetext{
kopyalar ilk olarak 1998 yılında Asitane Yayınları tarafından 13 cilt, ikinci olarak ise Diyanet İşleri Başkanlığı tarafından 2015 yılında, 13 cilt halinde tekrar ofset baskıyla basılmıştır.

${ }^{46}$ Hak Dini Kur'an Dili tefsirinin Osmanlıca el yazması kullanılarak metindeki atlamalar, tekrarlar, tercüme bozuklukları, cümle düşüklükleri, kopukluklar giderilmiş muhtasar çalışmadır.

${ }^{47} \mathrm{Bu}$ eserin 2013 baskısı da bulunmaktadır.
} 
6. Elmalıı M. Hamdi Yazır, Hak Dini Kur'ân Dili Elmalılı Tefsiri, (10 Cilt). Akçă̆ Yayınları, Sadeleştirenler: Lütfullah Cebeci-Orhan Atalay-Sadık Kılıç, Ankara 2013.

7. Elmalılı M. Hamdi Yazır, Hak Dini Kur'ân Dili, (10 Cilt). Sadeleştiren: Nedim Yılmaz, Hisar Yayınları, İstanbul 2016. ${ }^{48}$

8. Elmalılı M. Hamdi Yazır, Hak Dîni Kur'ân Dili Türkçe Tefsiri, (10 Cilt). Düzenleyen: Hamdi Döndüren, Çelik Yayınları, İstanbul 2018.

9. Elmalı1ı M. Hamdi Yazır, Hak Dini Kur'an Dili, Hazırlayanlar: Heyet, Harf Information Technology firması tarafindan Kur' an-1 Kerim Programı, sürüm 8 CD'sinde dağıtılmak üzere hazırlanmıştır.

\subsection{Hak Dini Kur'an Dili Tefsirine Dair İhtisar Çalışmaları}

1. Elmalılı M. Hamdi Yazır, Muhtasar Hak Dini Kur'an Dili: Meâl Tefsir, Hazırlayan: Nedim Yılmaz, Damla Yayınları, İstanbul 2005, 1264s. ${ }^{49}$

2. Elmalııı M. Hamdi Yazır, Muhtasar Hak Dini Kur'ân Dili: Meâl-Tefsir, Hazırlayan ve Notlandıran: Ertuğrul Özalp, İşaret Yayınları, İstanbul 2006, 1243s. ${ }^{50}$

\subsection{Hak Dini Kur'an Dili Tefsirinden Elde Edilen Kelime Meâli Çalışmaları}

1. Elmalılı M. Hamdi Yazır, Kur'an-ı Kerim Renkli Kelime Meâli, Renklendirerek Yayına Hazırlayan: Mustafa Özel, Asır Ajans, İstanbul 2006, 624s. ${ }^{51}$

2. Elmalılı M. Hamdi Yazır, Osmanlıca Kelime Anlamlı Kur'an-ı Kerim Meâli, (3 cilt). Derkenar ve Satırarası, Hazırlayan: Hasan Alioğlu, Cümle Yayınları, İstanbul 2007.

3. Elmalılı M. Hamdi Yazır, Kelime Meâlli Kur'an-ı Kerim, Elmalılı M Hamdi Yazır Meâli, Hazırlayanlar: Talha Alp, Necip Yılmaz, Yasin Yayınevi, İstanbul 2011, 604s.

4. Elmalılı M. Hamdi Yazır, Kur'an-ı Kerim ve Kelime Meâli, Hazırlayan: Kasım Yayla, Nevzat Dışbudak, Veysel Karaköse, Yasir Ünlü, Merve Yayınları, İstanbul 2011, 622s. ${ }^{52}$

5. Elmalılı M. Hamdi Yazır, Renkli Kelime Meâlli Kur'an-ı Kerim Güncel Türkçe ile Sadeleştirilmiş, Sadeleştiren: Murat Haliloğlu, Nuh Yayıncılık, İstanbul 2012, 620s..$^{53}$

6. Elmalılı M. Hamdi Yazır, Kur'an-ı Kerim ve Renkli Kelime Meâli, Hazırlayan: Mehmet Şirin Doğan, Abdüsselam Tunç, Seda Yayınları, İstanbul 2013, 640s.

7. Elmalııı M. Hamdi Yazır, Kelime Anlamlı Kur'an-ı Kerim Meâli, Hazırlayanlar: M. Sadi Çöğenli, Abdullah Karakuş, Huzur Yayınları, İstanbul 2013, 448s.

8. Elmalılı M. Hamdi Yazır, Kelime Anlamlı Kur'an-ı Kerim Meâli, Derleyici: Abdullah Karakuş, Huzur Yayın-Dağıtım, İstanbul 2013, 640s.

\footnotetext{
${ }^{48} \mathrm{Bu}$ çalışmalar dışında tefsirin daha önceden basımını ve dağıtımını gerçekleştiren Eser Yayınları tarafından da bir sadeleştirme yapılmış fakat diğer sadeleştirmelere göre daha az tutmuştur.

${ }^{49}$ Ayrıca Damla Yayınları, İstanbul 2012, 1264 sayfa olarak yayımlanmıştır.

${ }^{50}$ Ayrıca Kur'an-ı Kerim ve Meâli, Özgü Yayınları, İstanbul 2013, 1009s.; İşaret Yayınları, İstanbul 2013, 1416s. ve İşaret Yayınları, İstanbul 2017, 1518 sayfa olarak yayımlanmıştır.

${ }^{51}$ Ayrıca Haktan Yayın Dağıtım, Konya 2012, 622s.; Burhan Yayınları, İstanbul 2013, 616s.; Ayfa Basın Yayın, İstanbul 2014,

619s; Kur'an-ı Kerim Meâli Günümüz Türkçesi ile Sadeleştirilmiş Metin, Ebabil Kitap Yayıncılık, İstanbul 2015, 320 sayfa olarak yayımlanmıştır.

${ }^{52}$ Ayrıca Merve Yayınları, İstanbul 2013, 2014 ve 2018 yıllarında 622 sayfa olarak yayımlanmıştır.

${ }^{53}$ Ayrıca Nuh Yayıncılık, İstanbul 2014, 447s. ve Nuh Yayınc1lık, İstanbul 2015, 620s. baskıları da bulunmaktadır. Eserin En Kolay Okunan Hat ile Kur'an-ı Kerim ve Türkçe Meâli Güncel Türkçe ile Sadeleştirilmiş Elmalılı M. Hamdi Yazır ismiyle basılanları da vardır.
} 
9. Elmalılı M. Hamdi Yazır, Kuran-ı Kerim ve Satır Arası Kelime Kelime Türkçe Okunuşu ve Meâli, Editörler: Mahmut Tosun, Fahri Altunkaynak, Ahmet Çalar, Abdullah Sarıkaya, Haktan YayınDağıtım, Konya 2014, 624s.

10. Elmalı1 M. Hamdi Yazır, Kur'an-ı Kerim Satır Arası Transkript ve Tecvid İle Türkçe Kelime Okunuşlu, Hazırlayan: Mehmet Şirin Doğan, Seda Yayınları, İstanbul 2014, 639s. ${ }^{54}$

11. Elmalıı M. Hamdi Yazır, Kur'an-ı Kerim ve Renkli Kelime Meâli, Yayına Hazırlayan: Özen Çolak, Ayfa Basın-Yayın, İstanbul 2015, 624s.

12. Elmalıı M. Hamdi Yazır, Kur'an-ı Kerim ve Satır Arası Kelime Meâli Açılkamalı, Kervan YayınDağıtım, Hazırlayanlar: Fahri Altunkaynak, Ahmet Öncel, Yusuf Ertuğrul, Yasir Ünlü, Konya 2015, $616 \mathrm{~s}$.

\subsection{Hak Dini Kur'an Dili Tefsirinden Elde Edilen Nüzûl Sıralı Meâli Çalışmaları}

1. Elmalıı M. Hamdi Yazır, Nüzul Sırasına Göre Kur'an-ı Kerim Meâli, Hazırlayan: Mesut Okumuş, Birleşik Dağıtım, Ankara 1994, 463s. ${ }^{55}$

2. Elmalılı M. Hamdi Yazır, Nüzul Stralı Kur'an-ı Kerim Meâli, Sadeleştiren: Rauf Pehlivan, İstanbul Dağıtım, İstanbul 2002, 382s. ${ }^{56}$

\subsection{Hak Dini Kur'an Dili Tefsirinden Elde Edilen Meâller ve Sadeleştirme Çalışmaları}

Elmalılı M. Hamdi Yazır'ın tefsirinde bulunan meâl kısımları esas alınarak bir takım katkılarla müstakil meâller de oluşturulmuştur. Bu çalışmaların sayısının yirminin üzerinde olduğunu tespit ettik. Bunlardan büyük bir kısmının ticârî amaçlarla neşredildiğini düşünüyoruz. Bu meâlleri şöyle sıralamak mümkündür:

\section{i. İsmi Belirtilmiş Çalışmalar}

1. Elmalı1ı M. Hamdi Yazır, Hak Dini Kur'an Dili Meâli, Hazırlayanlar: Selahattin Kaya, Cahit Baltacı, Durali Yılmaz, Kerim Aytekin, Muhtar Yazır, Eser Neşriyat, İstanbul 1983, 604s.

2. Elmalılı M. Hamdi Yazır, Açıklamalı Kur'an-ı Kerim Meâli, Sadeleştirenler: M. Sadi Çöğenli, Nevzat H. Yanık, Huzur Yayınevi, İstanbul 1993, 448s.

3. Elmalılı M. Hamdi Yazır, Kur'an-ı Kerim Meâli: Hak Dini Kur'an Dili, Sadeleştirme ve Notlar: Muhammed Nur Doğan, İhtar Yayıncılık, Erzurum 1996, 472s.

4. Elmalılı M. Hamdi Yazır, Kur'an-ı Kerim ve İahlı Meâli, Hazırlayan: Nedim Yılmaz, Hisar Neşriyat, İstanbul 1996, 604s. ${ }^{57}$

5. Elmalılı M. Hamdi Yazır, Kur'an-ı Kerim ve İzahlı Meâli, Hazırlayanlar: Sadrettin Gümüş, Yakup Çiçek, Muhsin Demirci, Temel Neşriyat, İstanbul 2000, 606s. ${ }^{58}$

6. Elmalılı M. Hamdi Yazır, Kur'an-ı Kerim ve Türkçe Meâli, Hazırlayanlar: Yakup Çiçek, Necat Kahraman, Temel Neşriyat, İstanbul 2000, 606s.

\footnotetext{
${ }^{54}$ Eserin Elmalı1ı Muhammed Hamdi Yazır, Meâlli ve Transkript ve Tecvid ile Türkçe Kelime Okunuşu adıyla basılanları da vardır.

${ }^{55}$ Kur'ân ayetlerini nüzul sırasına göre anlama ve yorumlamanın imkân ve değeri için bkz. (Çalışkan, 2017: 414-415)

${ }^{56}$ Ayrıca İstanbul Dağıtım, İstanbul 2015, 455 sayfa olarak yayımlanmıştır.

${ }^{57}$ Ayrıca Damla Yayınları, İstanbul 2011, 604 sayfa olarak yayımlanmıştır.

${ }^{58}$ Ayrıca Kur'an-1 Kerim: Yüce Meâli, İpek Yayınları, İstanbul t.y., 345s; Temel Neşriyat, İstanbul 2002, 606 sayfa olarak yayımlanmıştır.
} 
7. Elmalııı M. Hamdi Yazır, Elmalılı Hak Dini Kur'ân Dili Meâl, Sadeleştiren: Sabri Yılmaz, Çelik Yayınevi, İstanbul 2001, 639s. ${ }^{59}$

8. Elmalılı M. Hamdi Yazır, Ayet Ayet Kur'an-ı Kerim ve Türkçe Meâli, Hazırlayan: Rauf Pehlivan, İstanbul Dağıtım, İstanbul 2002, 852s. ${ }^{60}$

9. Elmalılı M. Hamdi Yazır, Kur'ân-ı Kerîm Türkçe Meâli, Sadeleştiren: Halil Uysal, Uysal Kitabevi, Konya 2003, 439s. ${ }^{61}$

10. Elmalı1ı M. Hamdi Yazır, Kur'an-ı Kerîm ve Yüce Meâli, Sadeleştiren: Mustafa Kasadar, Ravza Yayınlar1, İstanbul 2004, 606s. ${ }^{62}$

11. Elmalı1ı M. Hamdi Yazır, Kur'an-ı Kerim Meâli, Sadeleştirenler: Mehmet Göktaş, Nezir Ergenç, Mehmet Durmuş, Okyanus Yayıncılık, Kayseri 2005, 320s. ${ }^{63}$

12. Elmalılı M. Hamdi Yazır, Kur'an-ı Kerim ve Açıklamalı Meâli, Hazırlayan: M. Sadi Çöğenli, Huzur Yayın-Dağıtım, İstanbul 2006, 632s. ${ }^{64}$

13. Elmalıı M. Hamdi Yazır, Kur'an-ı Kerim Yüce Meâli: Türkçe Açıklaması, Sadeleştiren: Sabri Y1lmaz, Şenyıldız Yayınevi, İstanbul 2006, 464s. ${ }^{65}$

14. Elmalıı M. Hamdi Yazır, Kur'an-ı Kerim ve Meâli, Yayına Hazırlayanlar: Ali Arslan, Cengiz Yağc1, Redaksiyon: Dücane Cündioğlu, Hikmet Neşriyat, İstanbul 2006, 612s.

15. Elmalıı M. Hamdi Yazır, Hak Dini Kur'an Dili Meâli, Sadeleştirenler: Lütfullah Cebeci-Sadık K1lıç, Akçağ Yayınevi, Ankara 2006, 702s. ${ }^{66}$

16. Elmalı1ı M. Hamdi Yazır, Kur'an-ı Kerîm ve Yüce Meâli, Sadeleştiren: Rıza Selçuk, Enes-Sarmaşık Yayınları, İstanbul 2007, 560s. ${ }^{67}$

17. Elmalı1ı M. Hamdi Yazır, Kur'an-ı Kerîm ve Yüce Meâli, Sadeleştiren: Necip Yılmaz, Yasin Yayınevi, İstanbul 2009, 560s.

18. Elmalıı M. Hamdi Yazır, Kur'an-ı Kerim ve Yüce Meâli, Sadeleştiren Mustafa Özer, Yolcu Yayinevi, İstanbul 2009, 624s. ${ }^{68}$

19. Elmalı1ı M. Hamdi Yazır, Kur'an-ı Kerim Meâli, Hazırlayan: Abdülkadir Dedeoğlu, Tuğra Yayınc1lı, İstanbul 2010, 291s.

20. Elmalı1ı M. Hamdi Yazır, Kur'an-ı Kerim ve Yüce Meâli, Hazırlayan: Kasım Yayla, Merve Yayınlar1, İstanbul 2010, 624s.

21. Elmalı1ı M. Hamdi Yazır, Kur'an-ı Kerim ve Yüce Meâli, Sadeleştiren: Mehmet Şirin Doğan, Seda Yayınlar1, İstanbul 2010, 638s.

22. Elmalı1ı M. Hamdi Yazır, Kur'ân-ı Kerim Meâli, Sadeleştiren: Lütfullah Müftüoğlu, Murat Haliloğlu, Telpa, İstanbul 2010, 447s.

\footnotetext{
${ }^{59}$ Ayrıca Şenyıldız Yayınevi, İstanbul 2006, 464 sayfa olarak yayımlanmıştır.

${ }^{60}$ Ayrıca Motif Yayınları, İstanbul 2005, 852s.; Motif Yayınları, İstanbul 2008, 736s.; Motif Yayınları, İstanbul 2014,852 sayfa olarak yayımlanmıştır.

${ }^{61}$ Ayrıca Kitapkent, Konya 2004'de yayımlanmıştır.

${ }^{62}$ Ayrıca İhvan Yayınevi, Bursa 2004, 624 sayfa olarak yayımlanmıştır.

${ }^{63}$ Ayrıca Okyanus Yayıncılık, Kayseri 2006, 320s.; Hicaz Yayıncılık, İstanbul 2010, 368 sayfa olarak yayımlanmıştır.

${ }^{64}$ Ayrıca Huzur Yayın-Dağıtım, İstanbul 2012, 448 sayfa olarak yayımlanmıştır.

${ }^{65}$ Ayrıca Şenyıldız Yayınevi, İstanbul 2010, 464 sayfa olarak yayımlanmıştır.

${ }^{66}$ Ayrıca Akçağ Yayınları, Ankara, t.y., 704s.;:Tuğra Kitap, İstanbul 2011, 350 sayfa olarak yayımlanmıştır.

${ }^{67}$ Ayrıca Enes-Sarmaşık Yayınevi, İstanbul 2007, 606 sayfa olarak yayımlanmıştır.

${ }^{68}$ Ayrıca Yolcu Yayınevi, İstanbul 2013, 624 sayfa olarak yayımlanmıştır.
} 
23. Elmalı1ı M. Hamdi Yazır, Kur'an-ı Kerim 'in Türkçe Anlamı, Hazırlayan: Aydın Hız, Serüven Kitap, Ordu 2010, 664s.

24. Elmalılı M. Hamdi Yazır, Kur'an-ı Kerim Türkçe Meâli, Sadeleştiren \& Dipnotlandıran: Kahraman Yusufoğlu, Kilim Matbaacılık, İstanbul 2011, 400s. ${ }^{69}$

25. Elmalılı M. Hamdi Yazır, Kur'an-ı Kerîm Meâli, Sadeleştiren: Mehmet Göktaş, İstişare Yayınevi, Kayseri 2011, 320s.

26. Elmalı1ı M. Hamdi Yazır, Kur'ân-ı Kerîm ve Türkçe Meâli, Editör: Erdem Bilgin, Nuh Yayınları, İstanbul 2011, 447s.

27. Elmalılı M. Hamdi Yazır, Kur'an-ı Kerim ve Yüce Meâli, Hazırlayan: Arif Pamuk, Pamuk Yayınc1lik, İstanbul 2011, 640s.

28. Elmalılı M. Hamdi Yazır, Kur'an-ı Kerim Meâli, Sadeleştirenler: Abdüsselam Tunç, Hüseyin Börekoğlu, Alperen Basım-Yayın, Ankara 2012, 634s.

29. Elmalılı M. Hamdi Yazır, Kur'an-ı Kerim ve Türkçe Meâli, Sadeleştirme: Osman Aracan, Haktan Yayın-Dağıtım, Konya 2012, 616s.

30. Elmalılı M. Hamdi Yazır, Kur'an-ı Kerim ve Türkçe Meâli, Sadeleştirme: A. Cevad Karaman, Kervan Yayın-Dağıtım, Konya 2012, 622s.

31. Elmalılı M. Hamdi Yazır, Kur'an-ı Kerîm ve Meâli, Yayına Hazırlayan: Resul Güzel, Asır, İstanbul 2012, 619s.

32. Elmalılı M. Hamdi Yazır, Kur'ân-ı Kerim ve Türkçe Meâli, Sadeleştiren ve Dipnotlar Ekleyen: Hamdi Döndüren, Çelik Yayınevi, İstanbul 2012, 628s.

33. Elmalılı M. Hamdi Yazır, Kur'an-ı Kerîm ve Elmalılı M. Hamdi Yazır Meâli, Hazırlayan: Talha Alp, Yasin Yayınevi, İstanbul 2013, 604s.

34. Elmalıı M. Hamdi Yazır, Kuran-ı Kerim Meâli, Hazırlayan: Süleyman Doğan, Alya Yayınları, İstanbul 2013, 287s.

35. Elmalılı M. Hamdi Yazır, Kuran-ı Kerim ve Açıklamalı Meâli, Katkıda Bulunan: Yunus Sağlam, Huzur Yayınevi, İstanbul 2013, 656s.

36. Elmalııı M. Hamdi Yazır, Kur'an-ı Kerim ve Meâli, Hazırlayan: Hüseyin Börekoğlu, Abdüsselam Tunç, Sefa Yayıncılık, Ankara 2013, 622s.

37. Elmalıı M. Hamdi Yazır, Kur'an-ı Kerîm Türkçe Meâli, Hazırlayan: Erdal Etyemez, Fırat Basım, İstanbul 2015, 93s.

38. Elmalı1ı M. Hamdi Yazır, Kur'an-ı Kerim Meâli, Derleyici: Abdülvehhab Öztürk, Kahraman Yayınları, İstanbul 2016, 411s.

39. Elmalı1ı M. Hamdi Yazır, Kur'an-ı Kerim Türkçe Meâli, Hazırlayan: İbrahim Cumalığlu, Milliyet Yayınları, İstanbul t.y., 522s.

40. Muhammed Hamdi Yazır, Kur'an-ı Kerim Meâli, Hazırlayan: Lütfullah Müftüoğlu, Frekans YayınDağıtım, İstanbul t.y., $413 \mathrm{~s}$.

41. Elmalılı M. Hamdi Yazır, Kur'an-ı Kerim ve Satır Arası Meâli, Hazırlayan: Osman Aracan, Feryal Matbaas1, Ankara t.y., 616s. ${ }^{70}$

\footnotetext{
${ }^{69}$ Ayrıca Sada Ajans, İstanbul 2011, 400 sayfa olarak yayımlanmıștır.

${ }^{70}$ Ayrıca Haktan Yayın Dağıtım, İstanbul t.y., 624 sayfa olarak yayımlanmıştır.
} 
42. Elmalı1ı M. Hamdi Yazır, Kur'an-1 Kerim Sesli Meali, Seslendiren: Seyfullah Kartal, Medrese Kitabevi, Afyon t.y.

\section{ii. İsmi Belirtilmemiş (Anonim) Çalışmalar}

1. Elmalılı M. Hamdi Yazır, Tefsirli Kur'an-ı Kerim Meâli, Eser Neşriyat, İstanbul 1998, 608s.

2. Elmalı1ı M. Hamdi Yazır, Kur'an-ı Kerim Meâli, Ahsen Yayınları, İstanbul 2000, 472s.

3. Elmalı1ı M. Hamdi Yazır, Kur'an-ı Kerim 'in Türkçe Meâli, Asır Ajans, İstanbul 2005, 430s.

4. Elmalılı M. Hamdi Yazır, Bilgisayar Hatlı Kur'an-ı Kerim ve Güncel Türkçe Ille Elmalılı Meâli, Akit Yayınları, İzmir 2008, 606s.

5. Elmalııı M. Hamdi Yazır, Kur'ân-ı Kerîm Meâli, BSR Yayın Grubu, İstanbul 2011, 368s.

6. Elmalılı M. Hamdi Yazır, Günümüz Türkçesiyle Yüce Kur'an-ı Kerim Açıklamalı Meâli, Burhan/Habertürk, İstanbul 2011. ${ }^{71}$

7. Elmalı1ı M. Hamdi Yazır, Kuran-ı Kerim Meâli, Altınpost Yayıncılık, Ankara 2012, 528s.

8. Elmalı1ı M. Hamdi Yazır, Kur'an-ı Kerîm ve Yüce Meâli, Mushaf Neşriyat, İstanbul 2012, 604s.

9. Elmalıı M. Hamdi Yazır, Kur'an-ı Kerim Meâli, Gece Kitaplı̆̆ı, Ankara 2014, 528s.

10. Elmalı1ı M. Hamdi Yazır, Kur'an-ı Kerim ve Türkçe Meâli, Gönül Yayınları, İstanbul 2014, 448s.

11. Elmalı1 M. Hamdi Yazır, Kur'an-ı Kerim Türkçe Meâl, Burhan Yayınları, İstanbul 2014, 616s.

12. Elmalı1ı M. Hamdi Yazır, Kur'an-ı Kerim Meâli, Sena Yayınları, İstanbul 2014, 287s.

13. Elmalılı M. Hamdi Yazır, Kur'ân-ı Kerim ve Türkçe Meâli, Andaç Yayınları, Ankara 2014, 446s.

14. Elmalı1ı M. Hamdi Yazır, Hak Dîni Kur'ân Dili: Türkçe Tefsir, Fazilet Neşriyat İstanbul 2016, 686s.

15. Elmalı1ı M. Hamdi Yazır, Kur'ân-ı Kerîm ve Meâli, Aktif Yayınevi, İstanbul 2016, 619s.

16. Elmalı1ı M. Hamdi Yazır, Kur'ân Meâl/Defter, Düşün Yayıncılık, İstanbul 2017, 727s.

\section{Elmalılı M. Hamdi Yazır ve Eserleri Üzerine Yapılmış Tezler}

Elmalılı M. Hamdi Yazır üzerine yapılan çalışmaları ilk olarak İlâhiyat Fakültelerinde yapılan lisans (mezuniyet) tezlerinden başlayarak şu şekilde tasnif etmek mümkündür.

\section{Elmalılı M. Hamdi Yazır ve Eserleri Üzerine Yapılmış Lisans (Bitirme) Tezleri}

\subsection{Tefsir Alanında Yapılan Lisans (Bitirme) Tezleri}

1. Muhittin Şamlığlu, "Elmalılı M. Hamdi Yazır: Hayatı ve Eserleri”, Ankara Üniversitesi İlahiyat Fakültesi, Ankara 1966, 18s.

2. Asım Uysal, Kadir Kesici, Kamil Uzun, Mustafa Köseoğlu, "Hak Dini Kur'an Dili Kılavuzu", Atatürk Üniversitesi İlahiyat Fakültesi, Erzurum 1981, 545s.

3. Mehmet Erdoğan, “Elmalılı M. Hamdi Yazır’a Göre Kur'ân-1 Kerim'deki Yaratma Hak”, Atatürk Üniversitesi İlahiyat Fakültesi, Erzurum 1982, 48s.

4. Osman Berber, "İbn Kesir, Fahrur Râzî, Nesefi, Âlûsî. Elmalılı, Konyalı ve+”, Atatürk Üniversitesi İlahiyat Fakültesi, Erzurum 1986, 109s.

\footnotetext{
${ }^{71}$ Ayrıca Yüce Kur'an-ı Kerim Açıklamalı Meâli, Hazırlayan: Hasan Karaosman, Burhan/Hürriyet, İstanbul t.y., Günümüz Türkçesiyle Yüce Kur'an-ı Kerim Açılamalı Meâli, Burhan/Habertürk, İstanbul 2011'de yayımlanmıştır.
} 
5. Güneş Kökoğlu, “Elmalılı Hamdi Yazır’ın Beyanu'l-Hak Mecmuasındaki Bazı Telif Makalelerinin Harf Çevirisi", Ankara Üniversitesi Kütüphane Kataloğu, Ankara 1992, 45s.

6. Nihat Haşlak, "Yûnus Sûresinin İbn-i Kesir, Elmalılı, Tefhîmu'l-Kur’ân, Fizila+”, Atatürk Üniversitesi İlahiyat Fakültesi, Erzurum 1993, 84s.

7. Özkan Kılbaş, "Enbiyâ Sûresinin Râzî, Elmalılı ve Tefhîmu'l-Kur'ân'a Göre Te+”, Atatürk Üniversitesi İlahiyat Fakültesi, Erzurum 1995, 57s.

8. Hasan Yavuz, "Elmalılı Hamdi Yazır'a Göre Kur'an'da Kadın”, Ankara Üniversitesi Kütüphane Kataloğu, Ankara 1999, 54s.

9. Murat Kaynar, "Hak Dini Kur'an Dili'nde Takva”, Ankara Üniversitesi Kütüphane Kataloğu, Ankara 1999, 39s.

10. Zehra Berna Hıdıroğlu, “Elmalılı Tefsiri’ne Göre Kadın”, Ankara Üniversitesi Kütüphane Kataloğu, Ankara 2000, 60s.

11. Nuray Özkaya, "Dilteyh'ın Anlama Yöntemi ve Buna Göre Elmalılı Tefsir Metodu”, Ankara Üniversitesi Kütüphane Kataloğu, Ankara 2000, 40s.

12. Feyza Ertuğrul, "Hak Dini Kur’an Dili Tefsirinde Kadın Yorumları", Ankara Üniversitesi Kütüphane Kataloğu, Ankara 2000, 45s.

13. Fatma Erol, "Hak Dini Kur'an Dili Tefsirinde Kadın Yorumları (İlk 5 Cild)", Ankara Üniversitesi Kütüphane Kataloğu, Ankara 2000, 54s.

14. Mehmet Toker, “Elmalılı Hamdi Yazır'ın -Hak Dini Kur'ân Dili- İsimli Tefsiri”, Hitit Üniversitesi İlahiyat Fakültesi Kütüphanesi, Çorum 2001, 164s.

15. Yaşar Daşkıran, Hak Dini Kur'an Dili'nde Terminolojik İnceleme (7-8-9 Ciltler)”, Ankara Üniversitesi Kütüphane Kataloğu, Ankara 2001, 58 y.

16. Ekrem Yaşar, "Haşr Sûresinin Elmalılı ve Muhammed Esed'e Göre Mukayeseli Te+", Atatürk Üniversitesi İlahiyat Fakültesi, Erzurum 2002, 58s.

17. Eşref Yaşar, “Kur’ân'da Övülen İnsan Davranışlarına Müfessir Elmalı1ı ve+”, Atatürk Üniversitesi İlahiyat Fakültesi, Erzurum 2002, 40s.

18. Ercan Sayılgan, “Abese Sûresi Tefsirinin İbn Kesir ve Elmalı1ı Hamdi Yazır+”, Atatürk Üniversitesi İlahiyat Fakültesi, Erzurum 2002, 41s.

19. Asiye Uzunca, "Mâide Sûresindeki Helaller ve Haramların Elmalılı ve Ateş+", Atatürk Üniversitesi İlahiyat Fakültesi, Erzurum 2002, 33s.

20. Zeliha Üzüm, "Nûr Sûresinin Kadın ve Aile Düzeni Bağlamında Elmalılı ve At+", Atatürk Üniversitesi İlahiyat Fakültesi, Erzurum 2002, 46s.

21. Hakan Sür, "Elmalılı M Hamdi Yazır'da Esbâb-1 Nüzûlün Yeri”, Atatürk Üniversitesi İlahiyat Fakültesi, Erzurum 2002, 35s.

22. Adnan Artan, "Kaf Sûresinin Razi İbn Kesir ve Elmalılı Tefsirleri Göre+", Atatürk Üniversitesi İlahiyat Fakültesi, Erzurum 2002, 73s.

23. Sümeyra Şeker, "Elmalılı Tefsirinde Kadın", Hitit Üniversitesi İlahiyat Fakültesi Kütüphanesi, Çorum 2002, $68 \mathrm{y}$.

24. Aytekin Canpolat, Yüce Kur'an'ın Çağdaş Tefsiri ve Hak Dini Kur'an Dili Tefsiri, Ankara Üniversitesi Kütüphane Kataloğu, Ankara 2004, 37s. 
25. Hatice Can, "Elmalılı Tefsirine Göre İslam'ın Tebliğinde Takip Edilecek +”, Ankara Üniversitesi İlahiyat Fakültesi Tefsir Anabilim Dalı, Ankara 2004, 31s.

26. Ömer Küçükceranlar, "Elmalılı M. Hamdi Yazır'da Muhkem Ve Müteşâbih”, Ankara Üniversitesi İlahiyat Fakültesi Tefsir Anabilim Dalı, Ankara 2004, 31 s.

27. Harun Albayrak, "Razi, İbn Kesir, Elmalılı ve Mevdûdî’ye Göre Muhammed Sûresinin Tefsiri”, Atatürk Üniversitesi İlahiyat Fakültesi, Erzurum 2004, 79s.

28. Rahmi Polat, “Razi, İbn Kesir, Elmalılı ve Süleyman Ateş’e Göre Necm Sûresinin Tefsiri”, Atatürk Üniversitesi İlahiyat Fakültesi, Erzurum 2004, 70s.

29. Enes Mutlu, “Kur'an-1 Kerim'deki Secde Ayetlerinin Elmalılı ve Razi Karşılaştırması”, Ankara Üniversitesi İlahiyat Fakültesi İlköğretim Din Kültürü ve Ahlak Bilgisi Öğretmenliği Bölümü, Ankara 2006, 35s.

30. Azer Nafiyev, "Şems Sûresinin Tefsiri: M. Vehbi Efendi, Elmalılı Hamdi Yazır ve Süleyman Ateş Tefsirlerinin Karşılaştırılması”, Marmara Üniversitesi Sosyal Bilimler Enstitüsü, İstanbul 2006, 44s.

31. Abdullah Tutak, "Elmalı1ı Hamdi Yazır Işı̆̆ında Kıyâmet Sûresinin Tefsiri”, Atatürk Üniversitesi İlahiyat Fakültesi, Erzurum 2006, 59s.

32. Fatih Sarıül, "Ahkâm Âyetlerine Verilen Mana Bakımından Cassas ve Elmalılı Tefsirlerinin Karşılaştırılması, Erciyes Üniversitesi Sosyal Bilimler Enstitüsü, Kayseri 2007, 100s.

33. Fatih Sarıgil, "Ahkâm Ayetlerine Verilen Mana Bakımından Cassas ve Elmalılı Tefsirlerinin Karşılaştırılması-Değerlendirilmesi”, Diyanet İşleri Başkanlığı, Akçaabat Danca İhtisas Eğitim Merkezi Müdürlüğü (Tefsir), Trabzon 2007.

34. İsmet Buzra, "Yâsin Sûresinin Elmalı11, Ö. N. Bilmen ve Süleyman Ateş'in Tefsirlerindeki Farklı Yorumları”, İstanbul Üniversitesi Kütüphaneleri Kataloğu, İstanbul 2008, 557 y.

35. Mehmet Mübin Düzgün, "Elmalılı Muhammed Hamdi Yazır ve Süleyman Ateş'in Kehf Sûresindeki Yorum Farkl11ıkları”, İstanbul Üniversitesi Kütüphaneleri Kataloğu, İstanbul 2010, 107 y.

36. Melike Nevruz, "Elmalı1ı Hamdi Yazır'da Tefsir Rivayetleri”, Ankara Üniversitesi Kütüphane Kataloğu, Ankara 2011, 100 y.

37. Elif Nur Türköz, "Fî Zilâl'l-Kur'ân ve Hak Dini Kur'an Dili Tefsirlerinde Kadın”, Ankara Üniversitesi Kütüphane Kataloğu, Ankara 2011, 45 y.

38. Zülfesen Aksi, "Hak Dini Kur'an Dili Tefsirinde Ahkâm Ayetlerinin Temizlik Ve İbadet Açısından Ele Alınışı”, Ankara Üniversitesi Kütüphane Kataloğu, Ankara 2012, 30 y.

39. Medine Kaya, "Elmalılı Hamdi Yazır'ın Tefsiri Işığında Yusuf Sûresinin İncelenmesi”, Atatürk Üniversitesi İlahiyat Fakültesi, Erzurum 2012, 39s.

40. Fatma Zehra Odabaşıŏlu, "Elmalılı Tefsirinde Kadın", İstanbul Üniversitesi Kütüphaneleri Kataloğu, İstanbul 2013, 79 y.

41. Abdullah Önder, “İbn Kesir (ö. 774/1372) Tefsirinin Çevirisi (Hadislerle Kur’an’1 Kerim Tefsiri) İçindeki Elmalılı (ö. 1362/1946) Tefsirinden Alıntılar”, Ankara Üniversitesi Kütüphane Kataloğu, Ankara 2013, $37 \mathrm{y}$.

42. Muhammet Saygı, "Elmalılı Hamdi Yazır, Süleyman Ateş ve Bayraktar Bayraklı'nın Tefsirlerinde Bazı Kırâat Farklılıkları ve Bunların Tefsire Yansıması", İstanbul Üniversitesi, İstanbul 2013, 40 y. 
43. Mustafa Yılmaz, "Muhammed Suresi Tefsiri ("Hak Dini Kur'an Dili”" ve Ruhu'l-Beyan” Örneği)”, Ankara Üniversitesi Kütüphane Kataloğu, Ankara 2013, 33 y.

44. Murat Biliç, "Elmalılı Hamdi Yazır'ın "Hak Dini Kur’ân Dili” Tefsirindeki Cihat Âyetlerinin Tefsiri", Atatürk Üniversitesi İlahiyat Fakültesi, Erzurum 2014, 110s.

45. Numan Öztürk, “Elmalılı Hamdi Yazır'ın Faiz Hakkındaki Değerlendirmeleri”, Atatürk Üniversitesi İlahiyat Fakültesi, Erzurum 2014, 34s.

46. Lale Baykay, "Elmalı1ı Hamdi Yazır Işı̆̆ında Târık Sûresinin Tefsiri ve İnsanın Yaratılış Gerçeği”, Atatürk Üniversitesi İlahiyat Fakültesi, Erzurum 2015, 73s.

47. Murat Koçak, "Fahreddin Razi İbn Kesir ve Elmalılı Hamdi Yazır'a Göre Cuma Sûresinin İncelenmesi" Atatürk Üniversitesi İlahiyat Fakültesi, Erzurum 2015, 41s.

48. Suat Yüksel, "Yâsin Sûresinin, Elmalılı Hamdi Yazır, İbn Kesir ve Fahreddin er-Râzi'ye Göre Tefsiri”, Atatürk Üniversitesi İlahiyat Fakültesi, Erzurum 2015, 177s.

49. Büşra Karabayır, "Elmalılı Hamdi Yazır Işı̆̆ında Burûc Sûresinin Tefsiri”, Atatürk Üniversitesi İlahiyat Fakültesi, Erzurum 2015, 67s.

50. Hilal Kavc1, "Elmalılı Hamdi Yazır'ın Tefsirinde Kısas Âyetleri”, Atatürk Üniversitesi İlahiyat Fakültesi, Erzurum 2015, 49s.

51. Cihat Duran, "Elmalı1ı M. Hamdi Yazır'ın Tefsirinde Takvâya Dair Yorumlar", Atatürk Üniversitesi İlahiyat Fakültesi, Erzurum 2015, 39s.

52. Tuba Alan, "Mutaffifîn Sûresi Tefsirinin İbn Kesir ve Elmalılı Muhammed Hamdi Yazır'a Göre Karşılaştırılması”, Atatürk Üniversitesi İlahiyat Fakültesi, Erzurum 2015, 46s.

53. Muhammed Kaça, "İbn-i Kesir, Fahreddin er-Razi ve Elmalılı Hamdi Yazır Tefsirlerinde Saffât Sûresi Analizi”, Atatürk Üniversitesi İlahiyat Fakültesi, Erzurum 2016, 88s.

54. Fatma Betül Özçelik, "Elmalılı Tefsirinde Kur'ân Meselelerinin Yorumu”, Atatürk Üniversitesi İlahiyat Fakültesi, Erzurum 2016, 40s.

55. Yusuf Akay, "Bakara Suresindeki Ahkâm Ayetleri Tefsirinin Mukayesesi (Elmal11ı Hamdi Yazır ve Ömer Nasuhi Bilmen Tefsirleri)", Ankara Üniversitesi Kütüphane Kataloğu, Ankara 2016, 103 y.

56. İbrahim Gündoğdu, "Elmalılı M. Hamdi Yazır'ın Tefsirinde Sünnetullah Kavramı”, Atatürk Üniversitesi İlahiyat Fakültesi, Erzurum 2016, 28s.

57. Vedat Ağveranlı, "Elmalılı Muhammed Hamdi Yazır, Fahreddin er-Razi, Seyyid Kutub, Mevdûdî Tefsirlerine Göre Mukayeseli Peygamber Duâları", Atatürk Üniversitesi İlahiyat Fakültesi, Erzurum 2016, 58s.

58. Nermin Yılmaz, "Haşr Sûresinin Elmalılı Hamdi Yazır ve Süleyman Ateşe Göre Tefsiri”, Atatürk Üniversitesi İlahiyat Fakültesi, Erzurum 2017, 37s.

59. Muhammed Hüseyin Sazan, “Talak Sûresinin Elmalı1ı Hamdi Yazır’a Göre Değerlendirilmesi”, Atatürk Üniversitesi İlahiyat Fakültesi, Erzurum 2017, 17s.

60. Fatma Yiğit, "Fahrettin er-Razi, Elmalılı Hamdi Yazır ve Bayraktar Bayraklı Tefsirlerinde Lût Kavmi Kıssası ve Eşcinsel Evliliği Yasallaştıran Ülkeler”, İstanbul Üniversitesi, İstanbul 2018, 68 y. 


\section{2 İslam Hukuku Alanında Yapılan Lisans (Bitirme) Tezleri}

1. A.Said Tunçpınar, "Elmalı1ı Muhammed Hamdi Yazır'ın Usûl-i Fıkıh Yönü”, Atatürk Üniversitesi İlahiyat Fakültesi, Erzurum 1997, 61s.

2. A.Hilmi Mutlu, "Muhammed Hamdi Yazır ve Mecelle İle İlgili Görüşleri”, Ankara Üniversitesi İlahiyat Fakültesi İslam Hukuku Anabilim Dalı, Ankara 1999, 68s.

3. Erzurum Kılıçoğlu, "Nikâh ve Talak Âyetlerinin Elmalılı M. Hamdi Yazır Tarafindan Değerlendirilmesi”, Atatürk Üniversitesi İlahiyat Fakültesi, Erzurum 2006, 83s.

4. Hayrunisa Kahraman, "Elmalı1ı M. Hamdi Yazır'ın "Hak Dini Kur'ân Dili” Tefsirinde Oruç Âyetlerinin Hukûkî Yönden İncelenmesi”, Atatürk Üniversitesi İlahiyat Fakültesi, Erzurum 2009, $64 \mathrm{~s}$.

5. Nuran Akyol, "Elmalılı Tefsirinde Kadınla İlgili Âyetler, Kadının Hukuki Sorumluluğu”, Atatürk Üniversitesi İlahiyat Fakültesi, Erzurum 2012, 43s.

6. Hasan Sulunoğlu, "Elmalılı Muhammed Hamdi Yazır'ın “Hak Dini Kur'ân Dili” Tefsirinde Cuma Namazı Hutbesi, Hükmü vb. Âyetlerin Değerlendirilmesi”, Atatürk Üniversitesi İlahiyat Fakültesi, Erzurum 2013, 45s.

7. Güven Fidan, "Elmalılı M. Hamdi Yazır'da Nikâh Konusu”, Atatürk Üniversitesi İlahiyat Fakültesi, Erzurum 2014, 46s.

8. Ahmet Emre Aydınlı, "Elmalılı Hamdi Yazır’ın İçki Kumar Hakkındaki Değerlendirmeleri”, Atatürk Üniversitesi İlahiyat Fakültesi, Erzurum 2014, 30s.

9. Hasan Terazi, "Elmalılı Hamdi Yazır'ın "Hak Dini Kur'ân Dili” Adlı Eserinde Oruç Konusu”, Atatürk Üniversitesi İlahiyat Fakültesi, Erzurum 2014, 51s.

10. Ali Akkaya, "Elmalılı Hamdi Yazır'ın "Hak Dini Kur'ân Dili” Adlı Eserinde Zekât Konusu”, Atatürk Üniversitesi İlahiyat Fakültesi, Erzurum 2014, 69s.

11. Mehmet Sadık Erdem, "Elmalılı Hamdi Yazır'ın "Hak Dini Kur'ân Dili” Adlı Tefsir Kitabında Gecen Hacc Âyetlerinin Tefsirleri”, Atatürk Üniversitesi İlahiyat Fakültesi, Erzurum 2014, 71s.

12. Osman Öztürk, "Elmalılı Hamdi Yazır ve Ömer Nasuhi Bilmen'in Tefsirinde Aile Hukuku ile İlgili Âyetlerin Mukayeseli İncelemesi", Atatürk Üniversitesi İlahiyat Fakültesi, Erzurum 2015, 32s.

13. İsmail Eroğlu, "Mîras Âyetlerinin Elmalılı Hamdi Yazır'a Göre Yorumu", Atatürk Üniversitesi İlahiyat Fakültesi, Erzurum 2017, 31 s.

14. Cafer Gezer, "Elmal111'da Kıraat Farkl111klarının F1kha Yansıması”, İstanbul Üniversitesi, İstanbul $2018,29 \mathrm{y}$.

\subsection{Kelam Alanında Yapılan Lisans (Bitirme) Tezleri}

1. Abdurrahim Yaşar, "Bediüzzaman Said Nursi ve Elmalılı M. Hamdi Yazır'ın Dua Anlayışı”, Ankara Üniversitesi Kütüphane Kataloğu, Ankara 1998, 39s.

2. Davut Küskü, “Elmalılı Muhammed Hamdi Yazır'ın Kader Konusundaki Ayetleri İzahı”, Ankara Üniversitesi Kütüphane Kataloğu, Ankara 1999, 43s.

3. Ayşe Aksakal, “Hak Dini Kur'an Dili Tefsiri’nde Ehl-İ Kitap'ın İnanç Esasları”, Ankara Üniversitesi Kütüphane Kataloğu, Ankara 2001, 66 y.

4. Bülent Yolcu. "Elmalılı M. Hamdi Yazır'ın Kelâm Problemlerine Bakışı", Atatürk Üniversitesi İlahiyat Fakültesi, Erzurum 2001, 47s. 
5. Zafer Uyar, "Ehl-i Kitabla İlgili Âyetlere Elmalılı Hamdi Yazır'ın Yorumu”, Hitit Üniversitesi İlahiyat Fakültesi Kütüphanesi, Çorum 2002, 64 y.

6. Hilal Kuzucu, "Elmalılı Muhammed Hamdi Yazır'ın Tefsirinde Dini Çeşitlilik", Ankara Üniversitesi İlahiyat Fakültesi Din Felsefesi Anabilim Dalı, Ankara 2004, 70s.

7. Zeki Halis, "Hak Dini Kur’ân Dili Tefsirinde Kelâmî Meselelerin İşlenişiı”, Atatürk Üniversitesi Sosyal Bilimler Enstitüsü Temel İslam Bilimleri Ana Bilim Dalı, Erzurum 2006, 15 y.

8. Dilek Işık, "Elmalılı Muhammed Hamdi Yazır'ın Düşüncesinde Âlemin Yaratılışı”, Ankara Üniversitesi Kütüphane Kataloğu, Ankara 2009, 67 y.

9. Yunus Selçuk Öztuncer, “Elmalılı Hamdi Yazır’da Kader Anlayışı”, Cumhuriyet Üniversitesi Kütüphane Kataloğu, Sivas, 2009, 25s.

10. Fatih Batdı, "Elmalılı M. Hamdi Yazır'ın Tefsirinde Şefâate Dair Yorumlar", Atatürk Üniversitesi İlahiyat Fakültesi, Erzurum 2014, 52s.

11. Nurdan Orçin, "Elmalılı Muhammed Hamdi Yazır'ın Ontolojik Argüman Eleştirisi”, Ankara Üniversitesi Kütüphane Kataloğu, Ankara 2015, 30 y.

12. Muhammed Tayyib Aslan, "Câmiu'l-Beyân ve Hak Dini Kur'an Dili’nde Levh-i Mahfûz”, Ankara Üniversitesi Kütüphane Kataloğu, Ankara 2015, 32 y.

13. Merve Bayar, "Elmalılı Hamdi Yazır'ın Kerâmete Bakışı”, Atatürk Üniversitesi İlahiyat Fakültesi, Erzurum 2016, 28s.

14. Sema Başsan, "Elmalılı Muhammet Hamdi Yazır'ın Tefsirinde Âhiret Bahsi”, Atatürk Üniversitesi İlahiyat Fakültesi, Erzurum 2017, 37s.

\subsection{Hadis Alanında Yapılan Lisans (Bitirme) Tezleri}

1. İsmet Ersöz, "Hak Dini Kur'ân Dili’nde Hadis İsti'mal Tarzı”, Lisans Tezi, Atatürk Üniversitesi İlâhiyat Fakültesi (Hadis), Erzurum 1976, 23s. ${ }^{72}$

2. Mürşide Işıı, "Hak Dini Kur’an Dilindeki (1. cilt) Türkçe Hadislerin Tahrici”, Ankara Üniversitesi Kütüphane Kataloğu, Ankara 1983, 23 s.

3. Münire Erdoğan, "Hak Dini Kur’an Dili 6. Cildindeki Türkçe Hadisler Üzerinde Bir Araştırma”, Ankara Üniversitesi Kütüphane Kataloğu, Ankara 1983, 16s.

4. Mehmet Keskin, "Hak Dini Kur'ân Dili IV. Ciltteki Hadislerin Tahrici”, Lisans Tezi, Ankara Üniversitesi Kütüphane Kataloğu, Ankara 1984, 30s.

5. Orhan Cerit, "Hak Dini Kur'ân Dili V. Ciltteki Hadislerin Tahrici”, Lisans Tezi, Ankara Üniversitesi Kütüphane Kataloğu, Ankara 1984, 18s.

6. Abdullah Şahin, "Hak Dini Kur'ân Dili VI. Ciltteki Hadislerin Tahrici”, Lisans Tezi, Ankara Üniversitesi Kütüphane Kataloğu, Ankara 1984, 21 s.

7. Adem Yiğitoğlu, "Hak Dini Kur'an Dili 9. Cilddeki Hadislerin Tahrici”, Ankara Üniversitesi Kütüphane Kataloğu, Ankara 1984, 33s.

\footnotetext{
${ }^{72} \mathrm{Bu}$ çalışma bazı kaynaklarda yüksek lisans olarak belirtilmektedir. Yapılan araştırmada lisans tezi olup (İsmet Ersöz "Elmalılı Mehmed Hamdi Yazır ve Hak Dini Kur'ân Dili”, Selçuk Üniversitesi İlâhiyat Fakültesi Temel İslâm Bilimleri Anabilim Dalı Tefsir Bilim Dalı, Konya 1985, ss. 84-117) isimli doktora tezinin içinde bir bölüm olduğu tespit edilmiştir.
} 
8. Önder Aslan, "Hak Dini Kur'an Dili Tefsirinin 3.Cildindeki Arapça ve Türkçe Hadislerin Tahrici”, Ankara Üniversitesi Kütüphane Kataloğu, Ankara 1989, 27s.

\section{5 İslam Felsefesi Alanında Yapılan Lisans (Bitirme) Tezleri}

1. Tahsin Görgün, “Hamdi Yazır'ın Görüşleri ve İlim Felsefesi”, Ankara Üniversitesi Kütüphane Kataloğu, Ankara 1984, 162s.

2. Ünal Üneş, "Hak Dini Kur'ân Dili Tefsirinde Tabiî İlimlerin Yeri”, Atatürk Üniversitesi Kütüphane Kataloğu, Erzurum 1984, 37s.

3. Hüseyin Başoğlu, "Elmalı1ı Hamdi Yazır ve Tecdid Anlayışı”, Hitit Üniversitesi İlahiyat Fakültesi Kütüphanesi, Çorum 2001, 58s.

4. Münevver Mücahide Yılmaz, "Elmalı1ı Muhammed Hamdi Yazır'ın Materyalizmi Eleştirisi”, Hitit Üniversitesi İlahiyat Fakültesi Kütüphanesi, Çorum 2002, 36 y.

5. Dilek Bozdemir, "Elmalılı Yazır Düşüncesinde Felsefe ve Akıl", Cumhuriyet Üniversitesi Kütüphane Kataloğu, Sivas 2007, 75s.

6. Hüseyin Ay, "Elmalı1ı Muhammed Hamdi Yazır'ın "Hak Dini Kur'ân Dili" Adlı Eserinde Evrim Teorisiyle Alakalı Görüşleri”, İstanbul Üniversitesi, İstanbul 2016, 71 y.

\subsection{Tasavvuf Alanında Yapılan Lisans (Bitirme) Tezleri}

1. Özkan Şimşek, "Elmalılı Tefsirinin Tasavvûfî Yönü”, Atatürk Üniversitesi İlahiyat Fakültesi, Erzurum 2005, 44s.

2. Öznur Aslan, “Elmalılı Muhammet Hamdi Yazır'a Göre Allah'ın Sevdiği ve Sevmediği Kullar ve Ameller", Atatürk Üniversitesi İlahiyat Fakültesi, Erzurum 2017, 47s.

3. Zehra Akkuzu, "Elmalılı Tefsirinde Tasavvûfî Yorumlar”, İstanbul Üniversitesi, İstanbul 2018, 143 $\mathrm{y}$.

\subsection{Din Felsefesi Alanında Yapılan Lisans (Bitirme) Tezleri}

1. Levent Hilmi İmamoğlu, "Elmalılı Hamdi Yazır'da Din-Felsefe Anlayışı”, Atatürk Üniversitesi İlahiyat Fakültesi, Erzurum 1997, 46s.

2. Fatma Şanverdi, "Elmalılı Hamdi Yazır ve İsmail Fenni Ertuğrul'un Kant'a Yönelik Eleştirileri”, Ankara Üniversitesi Kütüphane Kataloğu, Ankara 2014, 19 y.

\subsection{Din Eğitimi Alanında Yapılan Lisans (Bitirme) Tezleri}

1. Neslihan Muslu, "Elmalılı Hamdi Yazır'ın Tefsirinde İnsan Hakları”, Ankara Üniversitesi İlahiyat Fakültesi İlköğretim Din Kültürü ve Ahlak Bilgisi Öğretmenliği Bölümü, Ankara 2006, 29s.

\subsection{Dinler Tarihi Alanında Yapılan Lisans (Bitirme) Tezleri}

1. Betül Ciğerci, "Elmalılı Muhammed Hamdi Yazır'ın Tefsirinde Yahudiler”, Ankara Üniversitesi Kütüphane Kataloğu, Ankara 2010, 30 y.

\subsection{0 İslam Tarihi ve Sanatları Alanında Yapılan Lisans (Bitirme) Tezleri}

1. Zeliha Türker, "Elmalılı Muhammed Hamdi Yazır Tefsirinde Nüzul Sırasına Göre İlk 10 Surede Hz. Muhammed'in Hayatı", Ankara Üniversitesi Kütüphane Kataloğu, Ankara 2016, 54 y.

\subsection{Mezhepler Tarihi Alanında Yapılan Lisans (Bitirme) Tezleri}


1. Rabia Olçar, "Elmalı1ı Muhammed Hamdi Yazır'ın "Hak Dini Kur’ân Dili” Adlı Eserlere Mezhep Algisı”, Atatürk Üniversitesi İlahiyat Fakültesi, Erzurum 2014, 26s.

\section{Elmalılı M. Hamdi Yazır ve Eserleri Üzerine Yapılmış Yüksek Lisans Tezleri}

Yaptığımız araştırmada Elmalıı $\mathrm{M}$. Hamdi Yazır üzerine üniversitelerin Sosyal Bilimler Enstitülerince pek çok yüksek lisans çalışması yapılmış olduğu tespit edilmiştir. Bunları bilim dallarına göre şöyle sıralamak mümkündür.

\subsection{Tefsir Alanında Yapılan Yüksek Lisans Çalışmaları}

1. Nurettin Başyiğit, "Elmalı'da İlmî Tefsir", Uludağ Üniversitesi Temel İslâm Bilimleri Anabilim Dalı Tefsir Bilim Dalı, Bursa 1996, 120 y.

2. Alekber Muradov, "Elmalılı ve Tabatabâî Tefsirlerinde Siyasal İçerikli Ayetler ve Yorumları", Ankara Üniversitesi Temel İslâm Bilimleri Anabilim Dalı Tefsir Bilim Dalı, Ankara 2000, 84 y.

3. Oğuzhan Şemseddin Yağmur, "Elmalı1ı M. Hamdi Yazır'ın "Hak Dini Kur'ân Dili” Adlı Eserinde Esbâbü’n-Nüzûle Yaklaşımı", Dokuz Eylül Üniversitesi Temel İslâm Bilimleri Anabilim Dalı Tefsir Bilim Dalı, İzmir 2001, 189 y.

4. Recep Orhan Özel, "Elmalılı Hamdi Yazır'ın Bilimsel Tefsirciliği”, Cumhuriyet Üniversitesi Temel İslâm Bilimleri Anabilim Dalı Tefsir Bilim Dalı, Sivas 2002, 146 y.

5. İbrahim Tuncer, “Kur'ân'ın Modern Tevîli Açısından Elmalılı M. H. Yazır'ın Tefsiri”, Sakarya Üniversitesi Temel İslâm Bilimleri Anabilim Dalı Tefsir Bilim Dalı, Sakarya 2003, 96 y.

6. Bekir Bal, "Hak Dini Kur'ân Dili Tefsirinde İşarî Yön”, Dicle Üniversitesi Temel İslâm Bilimleri Anabilim Dalı Tefsir Bilim Dalı, Diyarbakır 2003, 149 y.

7. Canan Avan (Zerenay), "Elmalılı Muhammed Hamdi Yazır'ın Tefsirinde İsrâiliyât", Sakarya Üniversitesi Temel İslâm Bilimleri Anabilim Dalı Tefsir Bilim Dalı, Sakarya 2004, 83 y.

8. İbrahim Hakkı İmamoğlu, "Hak Dini Kur'ân Dili’nde Kelime Analizleri (I-V ciltler)”, Ankara Üniversitesi Temel İslâm Bilimleri Anabilim Dalı Tefsir Bilim Dalı, Ankara 2004, 417 y.

9. Rıfat Yıldız, "Elmalı1ı Hamdi Yazır'ın Nüzûl Sebepleri Değerlendirmesi”, Harran Üniversitesi Temel İslâm Bilimleri Anabilim Dalı Tefsir Bilim Dalı, Şanlıurfa 2006, 126 y.

10. Şerife Özdemir, "Elmalı1ı Hamdi Yazır'ın Kıssaları Tahlili”, Sakarya Üniversitesi Temel İslâm Bilimleri Anabilim Dalı Tefsir Bilim Dalı, Sakarya 2007, 100 y.

11. Hatice İslâmoğlu, "Elmalılı Tefsirinde Yahudi ve Hıristiyanlara Bakış", Harran Üniversitesi Temel İslâm Bilimleri Anabilim Dalı Tefsir Bilim Dalı, Şanlıurfa 2008, 130 y.

12. Durmuş Esen, “Elmalı11 M. Hamdi Yazır'ın "Hak Dini Kur'ân Dili” Tefsirinde Ulûmu'1-Kur'ân”, Sakarya Üniversitesi Temel İslâm Bilimleri Anabilim Dalı Tefsir Bilim Dalı, Sakarya 2008, 132 y.

13. Arif Çakır, "Hak Dini Kur'ân Dili" ve "Kur’ân Yolu" Tefsirlerinin Ahkâm Ayetleri Açısından Mukayesesi" Gazi Üniversitesi (Hitit Üniversitesi) Temel İslâm Bilimleri Anabilim Dalı Tefsir Bilim Dalı, Çorum 2008, 272 y.

14. Zehra Davarcı, "Hak Dini Kur'ân Dili” ve "Kur'ân Yolu” Tefsirlerinde Kadının Sosyal Statüsü”, Gazi Üniversitesi (Hitit Üniversitesi) Temel İslâm Bilimleri Anabilim Dalı Tefsir Bilim Dalı, Çorum 2008, 112 y.

15. Şükrü Çelik, "Hak Dini Kur'ân Dili Adlı Tefsirde Ahkâm Ayetlerinin Yorumu”, Cumhuriyet Üniversitesi İslâm Tarihi ve Sanatları Anabilim Dalı İslâm Tarihi Bilim Dalı, Sivas 2008, 222 y. 
16. Yıldıran Yalçın, "Elmalılı'nın “Hak Dini Kur’ân Dili” İsimli Tefsirinde Sûreler Arası Tenâsüb ve İnsicam”, Marmara Üniversitesi İlahiyat Anabilim Dalı Tefsir Bilim Dalı, İstanbul 2009, 204 y.

17. Tuğba Nur Tuğut, "Hak Dini Kur’ân Dili Tefsirinde Müşkilü’l-Kur’ân”, Marmara Üniversitesi İlahiyat Anabilim Dalı Tefsir Bilim Dalı, İstanbul 2009, 92 y.

18. Tugay Duran, "Elmalılı Tefsirinin Kıraat İlmi Açısından Değerlendirilmesi”, Rize Üniversitesi (Recep Tayyip Erdoğan Üniversitesi) Temel İslâm Bilimleri Anabilim Dalı Tefsir Bilim Dalı, Rize 2010, 117 y.

19. Murat Okuyar, "Kıraatlar Açısından Elmalılı ve Çantay Meâllerinin Değerlendirilmesi”, Atatürk Üniversitesi Temel İslâm Bilimleri Anabilim Dalı Tefsir Bilim Dalı, Erzurum 2012, 98 y.

20. Mehmet Arslan, "Elmalılı ile Süleyman Ateş'in Tefsirlerinin İşârî Yöntem Açısından Mukayesesi”, Eskişehir Osmangazi Üniversitesi Temel İslâm Bilimleri Anabilim Dalı Tefsir Bilim Dalı, Eskişehir 2013, 126 y.

21. Betül Arslanoğlu, "Elmalılı ve Muhammed Esed'in Tefsirlerinde Mucize ile İlgili Ayetlerin Mukayesesi”, Marmara Üniversitesi İlâhiyat Fakültesi Temel İslâm Bilimleri Anabilim Dalı Tefsir Bilim Dalı, İstanbul 2014, $117 \mathrm{y}$.

22. Ömer Şahingöz, “Hak Dini Kur'ân Dili’nde Nüzûl Sırasına Göre Tefsir Rivayetleri”, Ankara Üniversitesi Temel İslâm Bilimleri Anabilim Dalı Tefsir Bilim Dalı, Ankara 2014, 433 y.

23. Merve Erol, "Bilimsel Tefsir Yöntemi: Hamdi Yazır ve Süleyman Ateş Örneği”, Dokuz Eylül Üniversitesi Temel İslâm Bilimleri Anabilim Dalı Tefsir Bilim Dalı, İzmir 2014, 132 y.

24. Mehmet Kurt, "Elmalı1ı Tefsirinde Mucize-Bilim İlişkisi”, Erciyes Üniversitesi Temel İslâm Bilimleri Anabilim Dalı Tefsir Bilim Dalı, Kayseri 2014, 115 y.

25. Mehmet Yıldırım, "Elmalı1ı Meâl ve Tefsirinde Kur'ân Deyimlerinin Çevirisi”, Süleyman Demirel Üniversitesi Temel İslâm Bilimleri Anabilim Dalı Tefsir Bilim Dalı, Isparta 2014, 242 y.

26. Talha Şahin, "Hak Dini Kur'ân Dili Tefsirinde Dönemin Siyasi ve Sosyal Gelişmelerinin Yansımaları", Hitit Üniversitesi (Gazi Üniversitesi) Temel İslâm Bilimleri Anabilim Dalı Tefsir Bilim Dalı, Çorum 2015, 184 y.

27. Serkan Ünal, "Elmalı1ı Muhammed Hamdi Yazır'ın Hak Dini Kur’ân Dili İsimli Tefsirinde Tenkit Ettiği İlim Adamları İbn Sînâ ve Muhammed Abduh Örneği” Fatih Sultan Mehmet Vakıf Üniversitesi Sosyal Bilimler Enstitüsü Temel İslam Bilimleri Anabilim Dalı, İstanbul 2017.

\subsection{Kelam Alanında Yapılan Yüksek Lisans Çalışmaları}

1. Abdulhamit Sinanoğlu, "Elmalılı Muhammed Hamdi Yazır Tefsiri’nde Allah ve Âlem”, Yüzüncü Y1l Üniversitesi Temel İslâm Bilimleri Anabilim Dalı Kelam Bilim Dalı, Van 1995, 124 y.

2. İlhan Güneş, "Muhammed Hamdi Yazır'a Göre Allah'ın Varlığının Delilleri (İsbât-1 Vâcib)", Uludağ Üniversitesi Temel İslâm Bilimleri Anabilim Dalı Kelam Bilim Dalı, Bursa 1995, 77 y.

3. Yasin Çırçır, "Elmalılı Muhammed Hamdi Yazır'ın Peygamberlikle İlgili Görüşleri”, Uludağ Üniversitesi Temel İslâm Bilimleri Anabilim Dalı Kelam Bilim Dalı, Bursa 1995, 67 y.

4. Yalçın Topçu, "Elmalı1ı Muhammed Hamdi Yazır'a Göre İsbat-1 Vacib”, Erciyes Üniversitesi Temel İslâm Bilimleri Anabilim Dalı Kelam Bilim Dalı, Kayseri 1996, 131 y.

5. İkram Demirel, "Elmalılı Muhammed Hamdi Yazır'ın Ahiret Hayatı Hakkındaki Görüşleri”, Uludağ Üniversitesi Temel İslâm Bilimleri Anabilim Dalı Kelam Bilim Dalı, Bursa 1997, 102 y. 
6. Sabri Y1lmaz, "Elmalı1ı Tefsirinde Kader Problemi”, Dokuz Eylül Üniversitesi Temel İslâm Bilimleri Anabilim Dalı Kelam Bilim Dalı, İzmir 1997, 68 y.

7. Tevrat Çiçek, "Elmalılı Muhammed Hamdi Yazır'ın İtikada Dair Fikirlerinin Tesbiti ve Tahlili", Karadeniz Teknik Üniversitesi Temel İslâm Bilimleri Anabilim Dalı Kelam Bilim Dalı, Rize 1999, $102 \mathrm{y}$.

8. Zeki Halis, "Hak Dini Kur'ân Dili Tefsirinde Kelâmî Meselelerin İșlenişiı", Atatürk Üniversitesi Temel İslâm Bilimleri Anabilim Dalı Kelam Bilim Dalı, Erzurum 2006, 169 y.

9. Zeliha Şeker, “Hak Dini Kur'ân Dili'nin Kelâmî Açıdan İncelenmesi”, Çukurova Üniversitesi Temel İslâm Bilimleri Anabilim Dalı Kelam Bilim Dalı, Adana 2007, 106 y.

10. Ahmet Mesut Tutar, "Hak Dini Kuran Dili Adlı Eserde Ahiret İnancının İmkân ve Lüzumu”, Dicle Üniversitesi Temel İslâm Bilimleri Anabilim Dalı Kelam Bilim Dalı, Diyarbakır 2008, 94 y.

11. Kamil Kala, "Elmalı1ı Muhammet Hamdi Yazır’a Göre Kader-Rızık İlişkisi”, Kahramanmaraş Sütçü İmam Üniversitesi Sosyal Bilimler Enstitüsü Temel İslâm Bilimleri Anabilim Dalı, K. Maraş $2008,33 \mathrm{y}$.

12. Muhammet Necati Berberoğlu, "Elmalı1ı Muhammet Hamdi Yazır'ın Kelâmî Görüşleri” Selçuk Üniversitesi Temel İslâm Bilimleri Anabilim Dalı Kelam Bilim Dalı, Konya 2009, 88 y.

13. Mahsum Aytepe, "Hak Dini Kuran Dili Tefsiri'nde İman ve Küfür Kavramı", Yüzüncü Yı1 Üniversitesi Temel İslâm Bilimleri Anabilim Dalı Kelam Bilim Dalı, Van 2010, 101 y. ${ }^{73}$

14. Engin Yılmaz, "Said Nursi ve Elmalılı Hamdi Yazır'ın Ahiret Anlayışı", Sakarya Üniversitesi Temel İslâm Bilimleri Anabilim Dalı Kelam Bilim Dalı, Sakarya 2010, 100 y.

15. Bülent Akdaş, "Elmalılı Hamdi Yazır'da İmanın Temellendirilmesi” Dokuz Eylül Üniversitesi Temel İslâm Bilimleri Anabilim Dalı Kelam Bilim Dalı, İzmir 2010, 130 y.

16. Erol Köseoğlu, "Elmalılı Hamdi Yazır'ın Hak Dini Kur'ân Dili Adlı Eserinde İlahî Sıfatlar”, Dicle Üniversitesi Temel İslâm Bilimleri Anabilim Dalı Kelam Bilim Dalı, Diyarbakır 2011, 127 y.

17. Mehmet Şahin, "Elmalılı M. Hamdi Yazır'da Kur'ân Tasavvuru”, Harran Üniversitesi Temel İslâm Bilimleri Anabilim Dalı Kelam Bilim Dalı, Şanlıurfa 2013, 106 y.

18. Hüsna Çelebi, “Elmalılı Hamdi Yazır'da İrade-Meşîet Kavramı”, Dokuz Eylül Üniversitesi Temel İslâm Bilimleri Anabilim Dalı Kelam Bilim Dalı, İzmir 2013, 149 y.

19. Mustafa Koç, "Elmalılı M. Hamdi Yazır'da Kıyamet Alametleri ve Ölüm”, Harran Üniversitesi Temel İslâm Bilimleri Anabilim Dalı Kelam Bilim Dalı, Şanlıurfa 2016, 104 y.

20. Safet Alkış, "Elmalılı Hamdi Yazır'ın Kaza ve Kader Anlayışı”, Şırnak Üniversitesi Temel İslâm Bilimleri Anabilim Dalı Kelam Bilim Dalı, Şırnak 2016, 106 y.

\section{3 İslam Felsefesi Alanında Yapılan Yüksek Lisans Çalışmaları}

1. Coşkun Dikbıyık, “Elmalılı M. Hamdi Yazır'ın Felsefi Yönü ve Tefsirindeki Felsefi Unsurlar”, Marmara Üniversitesi Felsefe ve Din Bilimleri Anabilim Dalı İslâm Felsefesi Bilim Dalı, İstanbul 1986, 92 y.

\footnotetext{
${ }^{73} \mathrm{Bu}$ tez YÖK Tez Veritabanı'nda yer almamakta ancak İsam Illahiyat Fakülteleri Tezler Kataloğu'nda devam eden tezler arasinda görülmektedir.
} 
2. Kemal Göz, "Düşünce Tarihimizde Elmalılı Muhammed Hamdi Yazır", Süleyman Demirel Üniversitesi Felsefe ve Din Bilimleri Anabilim Dalı İslâm Felsefesi Bilim Dalı, Isparta 1998, 88 y.

3. Fatma Satılış, "Hak Dini Kur'ân Dili’nde Felsefi Unsurlar", Uludağ Üniversitesi Felsefe ve Din Bilimleri Anabilim Dalı İslâm Felsefesi Bilim Dalı, Bursa 2000, 75 y.

4. Ali Can, "Elmalılı Muhammed Hamdi Yazır'da Bilgi Problemi” Rize Üniversitesi (Recep Tayyip Erdoğan Üniversitesi) Felsefe ve Din Bilimleri Anabilim Dalı İslâm Felsefesi Bilim Dalı, Rize 2009, $120 \mathrm{y}$.

5. Nilüfer Kocabıyık (Öztürk), “Ontolojik Delilin Eleştirisi: Kant ve M. Hamdi Yazır Örneği”, Harran Üniversitesi Felsefe ve Din Bilimleri Anabilim Dalı İslâm Felsefesi Bilim Dalı, Şanlıurfa 2014, 121 $\mathrm{y}$.

\subsection{Dinler Tarihi Alanında Yapılan Yüksek Lisans Çalışmaları}

1. Arzu Aktaş, "Elmalılı Hamdi Yazır'ın Hak Dinî Kur’ân Dili Adlı Tefsirinde Hıristiyanlığa Yaklaşımı”, Selçuk Üniversitesi Felsefe ve Din Bilimleri Anabilim Dalı Dinler Tarihi Bilim Dalı, Konya 2005, 131 y.

2. Seyit Ali Cantürk, "Elmalılı Muhammed Hamdi Yazır'ın "Hak Dinî Kur'ân Dili” adlı Eserinde Hıristiyanlıkla İlgili Değerlendirmeleri”, Ankara Üniversitesi Felsefe ve Din Bilimleri Anabilim Dalı Dinler Tarihi Bilim Dalı, Ankara 2007, 110 y.

3. İbrahim Ethem Aydın, "Elmalı1ı Muhammed Hamdi Yazır'ın Hak Dini Kur'ân Dili Eseri'nde Yahudilik ile İlgili Bilgilerin Dinler Tarihi Açısından Değerlendirilmesi”, Fırat Üniversitesi Felsefe ve Din Bilimleri Anabilim Dalı Dinler Tarihi Bilim Dalı, Elazığ 2014, 142s.

4. Kazım Ural, “Elmalılı M. Hamdi Yazır'ın Hak Dini Kur’ân Dili Işı̆̆ııda Ehl-i Kitap Kavramı”, Atatürk Üniversitesi Felsefe ve Din Bilimleri Anabilim Dalı Dinler Tarihi Bilim Dalı, Erzurum 2015, $177 \mathrm{y}$.

\section{5 İslam Hukuku Alanında Yapılan Yüksek Lisans Çalışmaları}

1. Yasemin Yıldırım, "Elmalı1ı Hamdi Yazır'ın Ahkâm Âyetlerini Yorumlama Metodu”, Sakarya Üniversitesi Temel İslâm Bilimleri Anabilim Dalı İslâm Hukuku Bilim Dalı, Sakarya 2002, 82 y.

2. Elif Demirci, "Elmalıı Muhammed Hamdi Yazır'ın Kadınlarla İlgili Hukuki Görüşleri”, Gazi Üniversitesi (Hitit Üniversitesi) Temel İslâm Bilimleri Anabilim Dalı İslâm Hukuku Bilim Dalı, Çorum 2010, 117 y.

3. Selvinas Üzülmez, "Elmalı1ı Muhammed Hamdi Yazır'ın Fıkhî Görüşleri”, Cumhuriyet Üniversitesi Temel İslâm Bilimleri Anabilim Dalı İslâm Hukuku, Bilim Dalı, Sivas 2011, 147 y.

\subsection{Hadis Alanında Yapılan Yüksek Lisans Çalışmaları}

1. Abdurrahman Bestil, "Elmalılı Tefsirindeki Hadislerin Tahrîci" (I-III. Ciltler), Selçuk Üniversitesi Temel İslâm Bilimleri Anabilim Dalı Hadis Bilim Dalı, Konya 2004, 121 y.

2. Saliha Tekiner, "Elmalıı Tefsirindeki Hadislerin Tahrîci (IV, V, VI. Ciltler)" Selçuk Üniversitesi Temel İslâm Bilimleri Anabilim Dalı Hadis Bilim Dalı, Konya 2006, 178 y.

3. Bestami Gözalan, "Elmalılı Tefsirindeki Hadislerin Tahrîci (VII, VIII ve IX. Ciltler)", Selçuk Üniversitesi Temel İslâm Bilimleri Anabilim Dalı Hadis Bilim Dalı, Konya 2007, 248 y. 


\subsection{Din Felsefesi Alanında Yapılan Yüksek Lisans Çalışmaları}

1. Hüseyin Kurt, "Elmalılı Muhammed Hamdi Yazır'ın Felsefi Düşüncesi”, Ankara Üniversitesi Felsefe ve Din Bilimleri Anabilim Dalı Din Felsefesi Bilim Dalı, Ankara 1996, 128 y.

2. Yakup Yıldırım, "Elmalı1ı M. Hamdi Yazır’a Göre Bilgi-İman İlişkisi”, Selçuk Üniversitesi Felsefe ve Din Bilimleri Anabilim Dalı Din Felsefesi Bilim Dalı, Konya 2010, 80 y.

3. Salih Görgen, "Muhammed Hamdi Yazır’a Göre Ölüm ve Ölüm Sonrası Varoluş”, Erciyes Üniversitesi Felsefe ve Din Bilimleri Anabilim Dalı Din Felsefesi Bilim Dalı, Kayseri 2010, 69 y.

\subsection{Tasavvuf Alanında Yapılan Yüksek Lisans Çalışmaları}

1. Hatice Özsaraç, "Elmalılı M. Hamdi Yazır ve Tasavvuf Anlayışı”, Ankara Üniversitesi Temel İslâm Bilimleri Anabilim Dalı Tasavvuf Bilim Dalı, Ankara 1997, 147 y.

2. Mehmet Şirin Ayiş, "Elmalı1ı Tefsirinde Tasavvuf”, Yüzüncü Yı1 Üniversitesi Temel İslâm Bilimleri Anabilim Dalı Tasavvuf Bilim Dalı, Van 2001, 196 y.

\subsection{Din Psikolojisi Alanında Yapılan Yüksek Lisans Çalışmaları}

1. İbrahim Gürses, "Elmalılı Tefsirinde Psikoloji Konuları", Uludağ Üniversitesi İlâhiyat Fakültesi Felsefe ve Din Bilimleri Anabilim Dalı Din Psikolojisi Bilim Dalı, Bursa 1990, 73 y.

2. Emine Efendioğlu, "Elmalılı Muhammed Hamdi Yazır'ın Dinî Şahsiyeti”, Süleyman Demirel Üniversitesi Felsefe ve Din Bilimleri Anabilim Dalı Din Psikolojisi Bilim Dalı, Isparta 2015, 95 y.

\subsection{Din Sosyolojisi Alanında Yapılan Yüksek Lisans Çalışmaları}

1. Alaattin Dikmen, "Elmalı Tefsirinde Sosyolojik Yaklaşımlar", Uludağ Üniversitesi Felsefe ve Din Bilimleri Anabilim Dalı Din Sosyolojisi Bilim Dalı, Bursa 1994, 120 y.

2. Mustafa Özdemir, “Elmalılı M. Hamdi Yazır'ın Eserlerinde Din-Toplum İlişkisi”, Selçuk Üniversitesi Felsefe ve Din Bilimleri Anabilim Dalı Din Sosyolojisi Bilim Dalı, Konya 2007, 92 y.

\subsection{Din Eğitimi Alanında Yapılan Yüksek Lisans Çalışmaları}

1. Abdullah Akbaş, "Hak Dini Kur'ân Dili Adlı Tefsirde Bazı Ayetlerin Eğitim Açısından Değerlendirilmesi", Süleyman Demirel Üniversitesi Felsefe ve Din Bilimleri Anabilim Dalı Din Eğitimi Bilim Dalı, Isparta 2011, 171 y.

\subsection{Tarih Alanında Yapılan Yüksek Lisans Çalışmaları}

1. Ferdi Ertekin, "Geç Dönem Osmanlı Düşüncesinde Muhafazakâr Yenileşme Arayışları (18781918): Ahmed Cevdet Paşa, Babanzâde Ahmed Naim, Elmalılı Hamdi Yazır", İstanbul Üniversitesi Sosyal Bilimler Enstitüsü (Tarih), İstanbul 2014, 157 y.

\section{EImalılı M. Hamdi Yazır ve Eserleri Üzerine Yapılmış Doktora Tezleri}

Yaptığımız araştırma sonucunda Elmalıı M. Hamdi Yazır üzerine üniversitelerde sekiz doktora çalışmasının yaptırılmış olduğu tespit edilmiştir. Bunları şöyle sıralamak mümkündür:

1. Fahri Gökcan, "Commentaire du Coran Par Elmal1'lı", Faculté des Lettres et Sciences Humaines (Paris), 1970, 237s. Elmalılı M. Hamdi Yazır'ın tefsiri ve tefsirciliği üzerine yapılmış bir çalışmadır. (Yavuz, 1995: 62; Özel, 2001: 145).

2. İsmet Ersöz, "Elmalılı Mehmed Hamdi Yazır ve Hak Dini Kur’ân Dili”, Selçuk Üniversitesi İlâhiyat Fakültesi Temel İslâm Bilimleri Anabilim Dalı Tefsir Bilim Dalı, Konya 1985, 200 y. 
3. Mustafa Özel, "Elmalıı ile Mevdudi’nin Tefsirlerine Karşılaştırmalı Bir Yaklaşım”, Dokuz Eylül Üniversitesi İlâhiyat Fakültesi Temel İslâm Bilimleri Anabilim Dalı Tefsir Bilim Dalı, İzmir 1999, $214 \mathrm{y}$.

4. R. Adeviye Akbulut, “1919-1936 Yilları Arasında Türkiye'deki Tefsir Hareketleri”, Doktora Tezi, Harran Üniversitesi Temel İslâm Bilimleri Anabilim Dalı Tefsir Bilim Dalı, Şanlıurfa 2002.

5. Ahmet Faruk Güney, “İbn Sina'dan Elmalılı'ya İhlâs Sûresi Felsefî Tefsir Geleneği -Bir Varlık İdrakinin Zemini Olarak- İhlâs Sûresi Tefsiri”, Marmara Üniversitesi İlahiyat Fakültesi Temel İslâm Bilimleri Anabilim Dalı Tefsir Bilim Dalı, İstanbul 2008, 353 y.

6. Susan Gunasti, “Approaches to Islam in the Thoughts of Elmalili Muhammed Hamdi Yazir (18781942)", Princeton University, 2011.

7. Abdurrahman Aydın, "Et-Tefsîru'l-Kebîr ve Hak Dini Kur'ân Dili'nde Allah, Nübüvvet ve Ahiret Konularının Mukayesesi”, Ankara Üniversitesi İlâhiyat Fakültesi Temel İslâm Bilimleri Anabilim Dal1 Tefsir Bilim Dalı, Ankara 2015, 243 y.

8. Aladdın Sultanov, “Fahreddin er-Razi (v. 606/1209) ve Elmalılı'nın (v. 1361/1942) Yeryüzü ile İlgili Ayetlere Yaklaşımlarının Mukayesesi / Comparison of Fakhr al-Din Razi (D. 606/1209) and Elmalı11 Hamdi Yazir's (D. 1361/1942) approaches to Verses”, Marmara Üniversitesi Sosyal Bilimler Enstitüsü Temel İslam Bilimleri Anabilim Dalı Tefsir Bilim Dalı, İstanbul 2017, 242s.

\section{Elmalılı M. Hamdi Yazır ve Eserleri Üzerine Yapılmakta Olan Tezler}

\section{Devam Eden Yüksek Lisans Çalışmaları}

\subsection{Tefsir Alanında Devam Eden Yüksek Lisans Çalışmaları}

1. Ayşe Uçar, "Münasebât İlminin Semantik İlmindeki İzdüşümleri: Elmalı1ı ve Seyyid Kutup Örneği”, Erciyes Üniversitesi Temel İslâm Bilimleri Anabilim Dalı Tefsir Bilim Dalı, Kayseri.

2. Elif Özcan, “Hak Dini Kur'ân Dili’nde Te’vil”, Ankara Üniversitesi Temel İslâm Bilimleri Anabilim Dalı Tefsir Bilim Dalı, Ankara.

3. Fatih İzzet Çalışkan, "Elmalılı Muhammed Hamdi Yazır'ın Müteşabih Ayetleri Yorumlaması”, Cumhuriyet Üniversitesi Temel İslâm Bilimleri Anabilim Dalı Tefsir Bilim Dalı, Sivas.

4. Gülcan Ünlü, "Peygamberlere Saygı: Elmalılı Hamdi Yazır ve Süleyman Ateş Tefsirleri Üzerine Bir İnceleme”, Fatih Üniversitesi Temel İslâm Bilimleri Anabilim Dalı Tefsir Bilim Dalı, İstanbul.

5. Hilmi Kemal Yurdakul, "Fiziki Coğrafya İle İlgili Ayetlerin Tefsirinde Bilimsel Gelişmelerin Etkisi (Razî-Elmalılı Örneği)", Sakarya Üniversitesi Temel İslâm Bilimleri Anabilim Dalı Tefsir Bilim Dal, Sakarya.

6. Celalettin Alkan, "Hak Dini Kur'an Dili" ve "Kur'an Yolu" Tefsirlerinde Nesh Meselesine Yaklaşımlar", Trakya Üniversitesi Temel İslâm Bilimleri Anabilim Dalı Tefsir Bilim Dalı, Edirne.

7. Murat Susam, “Tefsirde Tercih Olgusu - Hak Dini Kur’an Dili Örneği”, Aksaray Üniversitesi Temel İslâm Bilimleri Anabilim Dalı Tefsir Bilim Dalı, Aksaray.

8. Hilmi Kemal Yurdakul, "Fiziki Coğrafya İle İlgili Ayetlerin Tefsirinde Bilimsel Gelişmelerin Etkisi (Razî - Elmalılı Örneği)", Sakarya Üniversitesi Temel İslâm Bilimleri Anabilim Dalı Tefsir Bilim Dal, Sakarya.

9. Harun Özbayrak, “Elmalılı'nın Hak Dini Kur'an Dili Tefsirinde Garibu'l-Kur'an ve Garib Kelimelerin Tefsiri”, Atatürk Üniversitesi Temel İslâm Bilimleri Anabilim Dalı Tefsir Bilim Dalı, Erzurum. 
10. Abdullah Tunç, "Elmalılı Muhammed Hamdi Yazır'ın Aile Hukukuna İlişkin Ayetlerin Yorumu”, Iğdır Üniversitesi Temel İslâm Bilimleri Anabilim Dalı Tefsir Bilim Dalı, Iğdır.

11. Venhar Özer, "Elmalılı M. Hamdi Yazır'ın Fahreddin er-Razi'den Etkilenmesi ve Yararlanma Tarzı”, Erciyes Üniversitesi Temel İslâm Bilimleri Anabilim Dalı Tefsir Bilim Dalı, Kayseri.

12. Mehmet Yalınkılıç, "Elmalılı Muhammed Hamdi Yazır'ın Müşkil Ayetlere Yaklaşımı", Kahramanmaraş Sütçü İmam Üniversitesi Temel İslâm Bilimleri Anabilim Dalı Tefsir Bilim Dalı, K. Maraș.

13. Nezicha Serif, "Elmalılı Tefsirindeki Yaratılışla İlgili Ayetlerin Değerlendirilmesi”, Trakya Üniversitesi Temel İslâm Bilimleri Anabilim Dalı Tefsir Bilim Dalı, Edirne.

14. Hüseyin Ay, "Elmalılı Muhammed Hamdi Yazır'ın "Hak Dini Kur'an Dili"' İsimli Eserinde Tekâmül Nazariyesi ile İlgili Görüşlerinin İncelenmesi", İstanbul Üniversitesi Temel İslâm Bilimleri Anabilim Dalı Tefsir Bilim Dalı, İstanbul.

\subsection{Kelam Alanında Devam Eden Yüksek Lisans Çalışmaları}

1. Ercan Akgün, “Elmalı1ı Hamdi Yazır’ın Tefsiri Bağlamında Kelâmî Görüşleri”, Fırat Üniversitesi Temel İslâm Bilimleri Anabilim Dalı Kelam Bilim Dalı, Elazı̆̆g.

2. Vildan Emirbilek, "Elmalılı Hamdi Yazır'a Göre Fitrat Delili (Hak Dini Kur'an Dili Adlı Tefsiri Bağlamında)", Marmara Üniversitesi Temel İslâm Bilimleri Anabilim Dalı Kelam Bilim Dalı, İstanbul.

3. Yasin Günaydın, "Elmalı1ı Muhammed Hamdi Yazır'ın İnsan Tasavvuru”, Necmettin Erbakan Üniversitesi Temel İslâm Bilimleri Anabilim Dalı Kelam Bilim Dalı, Konya.

4. Aziz Aydın, "Elmalılı'ya Göre Varlık Yaratma-Problemi”, Dokuz Eylül Üniversitesi Temel İslâm Bilimleri Anabilim Dalı Kelam Bilim Dal, İzmir.

5. Selahaddin Kaya, "Elmalılı'da Rızık ve Ecel Problemi”, Akdeniz Üniversitesi Temel İslâm Bilimleri Anabilim Dalı Kelam Bilim Dalı, Antalya.

6. Vildan Emirbilek, "Elmalılı Hamdi Yazır'a Göre Fıtrat Delili (Hak Dini Kur'an Dili Adlı Tefsiri Bağlamında)", Marmara Üniversitesi Temel İslâm Bilimleri Anabilim Dalı Kelam Bilim Dalı, İstanbul.

7. Farid Ahmad Ubaydi, "Elmalılı Hamdi Yazır’ın Pozitivizm'e Karşı İslam İnanç Esaslarının Müdafaası", Necmettin Erbakan Üniversitesi Temel İslâm Bilimleri Anabilim Dalı Kelam Bilim Dal1, Konya.

\subsection{Din Felsefesi Alanında Devam Eden Yüksek Lisans Çalışmaları}

1. Sevgül Demirayak, "Elmalılı Muhammed Hamdi Yazır'a Göre Allah'ın Varlığı”, Erciyes Üniversitesi Felsefe ve Din Bilimleri Anabilim Dalı Din Felsefesi Bilim Dalı, Kayseri.

2. Sümeyye Karakuş, "Elmalılı Muhammed Hamdi Yazır'a Göre İnsan Hürriyeti”, Erciyes Üniversitesi Felsefe ve Din Bilimleri Anabilim Dalı Din Felsefesi Bilim Dalı, Kayseri.

\section{4 İslam Tarihi ve Sanatları Alanında Devam Eden Yapılan Yüksek Lisans Çalışmaları}

1. Muhammet Özyurt, "Elmalılı Hamdi Yazır'ın Eserlerindeki Tarihi Muhtevanın Değerlendirilmesi”, Recep Tayyip Erdoğan Üniversitesi İslâm Tarihi ve Sanatları Anabilim Dalı İslâm Tarihi Bilim Dall, Rize. 
2. Merve Doğruyol, “Elmalıı M. Hamdi Yazır'ın (ö. 1942) Hak Dini Kur’an Dili Adlı Eserindeki Siyer Bilgilerinin Tespiti ve Tahlili”, Sakarya Üniversitesi İslâm Tarihi ve Sanatları Anabilim Dalı İslâm Tarihi Bilim Dalı, Sakarya.

\subsection{Din Ĕ̈itimi Alanında Devam Eden Yüksek Lisans Çalışmaları}

1. Zuhal Türkmen, "Elmalılı Hamdi Yazır'ın Tefsirindeki Eğitim-Öğretimle İlgili Ayetlerin Din Eğitimi Öğretimi Açısından Değerlendirilmesi”, Dokuz Eylül Üniversitesi Felsefe ve Din Bilimleri Anabilim Dalı Din Eğitimi Bilim Dalı, İzmir.

\section{6 İslam Felsefesi Alanında Devam Eden Yüksek Lisans Çalışmaları}

1. Mustafa Ceylan, "Meşrutiyet'ten Cumhuriyet'e Geçişte İslamcıların Felsefeye Bakışı (Babanzade Ahmet Naim ve Elmalı1ı Hamdi Yazır Örnekliğinde)", Necmettin Erbakan Üniversitesi Felsefe ve Din Bilimleri Anabilim Dalı İslâm Felsefesi Bilim Dalı, Konya.

\subsection{Dinler Tarihi Alanında Devam Eden Yüksek Lisans Çalışmaları}

1. İbrahim Gül, “M. Hamdi Yazır'ın Hak Dini Kur'an Dili Adlı Tefsirinin Dinler Tarihi Açısından İncelenmesi”, Uludağ Üniversitesi Felsefe ve Din Bilimleri Anabilim Dalı Dinler Tarihi Bilim Dalı, Bursa.

\section{Devam Eden Doktora Tezleri}

\subsection{Tefsir Alanında Devam Eden Doktora Çalışmaları}

Bilal Işık, "Elmalılı Hamdi Yazır ve Seyyid Kutub’un Nehiy Âyetlerini Yorumlamaları", Marmara Üniversitesi Temel İslâm Bilimleri Anabilim Dalı Tefsir Bilim Dalı, İstanbul.

\subsection{Hadis Alanında Devam Eden Doktora Çalışmaları}

1. Recep Bilgin, "Bir Müfessirin Hadisçiliği, -Elmalılı M. Hamdi Yazır Örneği-” Sütçü İmam Üniversitesi Sosyal Bilimler Enstitüsü Temel İslâm Bilimleri Anabilim Dal1, K. Maraş. ${ }^{74}$

\section{E. Elmalılı M. Hamdi Yazır ve Eserleri ile İlgili Makaleler}

\section{Elmalılı M. Hamdi Yazır ve Eserleri ile İlgili Hakemli Dergilerde Yayımlanan} Makaleler

\subsection{Tefsir Alanında Yazılan ve Hakemli Dergilerde Yayımlanan Makaleler}

1. “Ölüm Yı1dönümü Dolayısıyle: Elmalı1ı Küçük Hamdi Efendi”, Diyanet İlmi Dergi (Diyanet İşleri Reisliği Yıllığı), cilt: III, sayı: 5, ss. 144-145, Ankara 1964.

2. Ali Yılmaz, "Elmalılı Hamdi Yazır'ın Türkçesi”, Din Öğretimi Dergisi, sayı: 32, ss. 72-83, Ankara 1992.

3. Halis Albayrak, "Elmalılı Muhammed Hamdi Yazır'ın Tefsir Anlayışı”, Ankara Üniversitesi İlahiyat Fakültesi Dergisi (AÜİFD), cilt: 34, sayı: 1, ss. 155-173, Ankara 1993. ${ }^{75}$

4. Ahmed Nedim Serinsu, "Elmalılı M. Hamdi Yazır'ın Fransızca'yı Öğrenişi Hakkında Bir Hatıra”, Diyanet İlmi Dergi (Diyanet İşleri Reisliği Yıllığı), cilt: 31, sayı: 2, ss. 101-106, Ankara 1995.

\footnotetext{
${ }^{74}$ Devam eden tezleri tespitte kaynak olarak kullanılan ISAM Devam Eden Tezler Veri Tabanı ve YÖK Tez Veri Tabanı'nda yapılan taramalarda bulunmasa da Necmi Atik'e ait CV'nin yayınlandığı bir sitede onun, Ankara Üniversitesi Sosyal Bilimler Enstitüsü'nde "Elmalılı Muhammed Hamdi Yazır, Hayatı, Eserleri ve Divançesi" adlı doktora tezine devam ettiği belirtilmektedir. https://docplayer.biz.tr (Erişim 30.03.19)

${ }^{75}$ Elmalılı Muhammed Hamdi Yazır Sempozyumu'nda bildiri olarak da sunulmuştur. Elmalılı Muhammed Hamdi Yazır Sempozyumu, Antalya/Elmalı, 4-6 Eylül 1991, ss. 152-168, Ankara 1993.
} 
5. Hidayet Aydar, “Türklerde Kur'an Çalışmaları”, İstanbul Üniversitesi İlahiyat Fakültesi Dergisi, say1: 1, ss. 159-235, İstanbul 1999.

6. Mustafa Özel, “Hak Dini Kur’ân Dili Üzerine Yapılan Akademik Çalışmalar”, İslâmi Araştırmalar Dergisi, cilt: XIV, sayı: 1, ss. 145-149, Ankara 2001.

7. Muhammed Çelik, "İşâ̂î Tefsirinin Sınırları ve Elmalılı Hamdi Yazır'da İşârî Tefsiri”, Dicle Üniversitesi İlahiyat Fakültesi Dergisi, cilt: IV. sayı: 2, ss. 1-28, Diyarbakır 2002.

8. Muhammed Aydın, "Hamdi Yazır Elmalılı ve Menhecuhu fi't-Tefsîr “ محمّد حمدي يازير ألماليلي ومنهجه "في التفسير Usûlid-Dîn, sayı: 20, ss. 736, Kahire 2003.

9. Ismail Albayrak, "The Notions of Muhkam and Mutashābih in the Commentary of Elmali'li Muhammad Hamdi Yazir” Journal of Qur'anic Studies, Vol.5(1), p. 19-34. 2003.

10. Ismail Albayrak, "Turkish Exegeses of the Twentieth Century: Hak Dini Kur'an Dili" Islamic Studies, Vol. 43, No. 3 pp. 391-413, Autumn 2004.

11. Suat Yıldırım, "Yazır ile Nursi'nin Müteşabih Ayetleri Anlamaya Katkıları", Usûl İslam Araştırmaları Dergisi, sayı: 1, ss. 49-68, (Ocak-Haziran), İstanbul 2004.

12. İbrahim Hilmi Karslı, "Çeviri Kuramları Açısından M. Hamdi Yazır'ın Meâl Yöntemi”, Cumhuriyet Üniversitesi İlahiyat Fakültesi Dergisi, cilt: IX, sayı: 1, ss. 231-255, Sivas 2005.

13. Sabri Yılmaz, "Elmalılı Hamdi Yazır'ın Allah'ın Rahman ve Rahim Sıfatlarını Tahlili”, Kelâm Araştırmaları Dergisi, cilt: IV, sayı: 2, ss. 105-114, Karabük 2006.

14. Hasan Yılmaz, "Elmalılı ve Çantay'ın Mukaddimeleri Özelinde Çeviri Olgusu ve Kur'ân Meâllerine Dair”, Atatürk Üniversitesi İlahiyat Fakültesi Dergisi, sayı: 30, ss. 93-119, Erzurum 2008.

15. M. Brett Wilson, “The First Translations of The Qur'an in Modern Turkey (1924-38)”, International Journal of Middle East Studies, Vol. 41(3), pp. 419-435, 2009.

16. Tahsin Görgün, "Elmalılı Hamdi Yazır Mazi ile İstikbal Arasında Bir Köprü”, İslâmi Edebiyat Dergisi, say1: 54, ss. 32-35, İstanbul 2011.

17. Mustafa Öztürk, “II. Meşrutiyet’ten Günümüze Kur'an Meâlleri”, Türkiye Araştırmaları Literatür Dergisi, cilt: IX, say1: 18, ss. 139-189, İstanbul 2011.

18. M. Suat Mertoğlu, "Osmanlı ve Cumhuriyet Dönemi Kur'an ve Tefsir Literatürüne Toplu Bir Bakış -Birincil Eserler ve Onlara Dair İncelemeler-”, Türkiye Araştırmaları Literatür Dergisi, cilt: IX, say1: 18, ss. 9-66, İstanbul 2011.

19. Muhammet Abay, “Türkçedeki Kur'an Meâllerinin Tarihi ve Kronolojik Bibliyografyası”, Türkiye Araştırmaları Literatür Dergisi, cilt: X, sayı: 19-20, ss. 231-301, İstanbul 2012.

20. Mehmet Demirci, “Hamdi Yazır'da Hak Kavramı”, Bilimname: Düşünce Platformu, sayı: 22, ss. 61-85, Kayseri 2012.

21. İshak Özgel, "Elmalılı Muhammed Hamdi Yazır'ın Tefsiri ve Hakkında Yapılmış Çalışmalar Bibliyografyası", Türkiye Araştırmaları Literatür Dergisi, cilt: X, sayı: 19-20, ss. 327-362, İstanbul 2012.

22. Abdurrahman Altuntaş, "Hak Dini Kur'ân Dili Tefsiri'nde Şûrâ Kavramının Ele Alınışı", Gümüşhane Üniversitesi İlahiyat Fakültesi Dergisi, cilt: I, sayı: 2, ss. 245-264, Gümüşhane 2012. 
23. Mustafa Özel, “Elmalılı'nın Meâlinin Bazı Özellikleri”, Diyanet İlmî Dergi, ss. 553-576, (Diyanet İşleri Reisliği Yıllığı, Özel Sayı), Ankara 2012.

24. Bilal Gökkır, "The Role of State Policies in Modern Qur'anic Exegesis in Turkey: Case of Elmal11 Muhammed Hamdi Yazır (1878-1942) and His Exegesis" say1: 25, ss. 133-145, Acta Asiatica Varsoviensia 2012.

25. Ali Öge, "Elmalılı Muhammed Hamdi Yazır'ın Tefsirinde Kıraatlerin Kullanımı", Necmettin Erbakan Üniversitesi İlahiyat Fakültesi Dergisi (Selçuk Üniversitesi İlahiyat Fakültesi Dergisi), say1: 34, ss. 51-82, Konya 2012.

26. Şerif Demir, "Beyân'ül-Hak Mecmuası ve Hamdi Efendi”, Selçuk Üniversitesi Türkiyat Araştırmaları Dergisi, say1: 32, ss. 309-325, Konya 2012.

27. Recep Orhan Özel, "Elmalılı Hamdi Yazır'ın Bilimsel Tefsir Anlayışı”, Osmanlı Toplumunda Kur'ân Kültürü ve Tefsir Çalışmaları -II-, ss. 549-571, İstanbul 2013.

28. Erol Kılıç, "Elmalılı Hamdi Muhammed Yazır ve Hak Dini Kur’ân Dili Tefsirinin Özellikleri”, Rehber Dergisi, say1: 27, (Ocak) Ankara 2013.

29. Susan Gunasti, "Political Patronage and the writing of Qur' ān commentaries among the Ottoman Turks" Journal of Islamic Studies, Vol. 24(3), pp. 335-357, 2013. ${ }^{76}$

30. Wilson M. Brett, “The Ulama's Best And Brightest: Elmalılı Muhammed Hamdi Yazır (1878/1942)", Translating the Qur'an in an Age of Nationalism: Print Culture and Modern Islam in Turkey, The İnstute of İsmaili Studies, ss. 226-228, London 2014.

31. Hidayet Aydar, "Yaygınlık Bakımından Meallerimiz ve Mealler Üzerinde İstatistiksel Bir Değerlendirme”, FSM İlmi Araştırmalar İnsan ve Toplum Bilimleri Dergisi, sayı: 5, s. 109-147, İstanbul 2015.

32. Mustafa Güven, "Elmalılı Muhammed Hamdi Yazır'ın Tefsir Anlayışındaki Modernlik Unsurları ve Bu Bağlamda Muhammed Abduh'a Yönelttiği Eleştiriler- Fil Sûresi Örneği”, EKEV Akademi Dergisi, Y11: 19, sayı: 61, ss. 141-170, Erzurum 2015.

33. Mustafa Özel, “Elmalılı'nın Tefsir Metodolojisi”, Diyanet İlmî Dergi (Diyanet İşleri Reisliği Y1llığı), cilt: LI, sayı. 3, ss. 29-57, Ankara 2015. ${ }^{77}$

34. Zülfikar Durmuş, "Elmalılı'nın Meâlinde Çok Anlamlılık Problemine Yaklaşımı (Lafız-Mana İlişkisi), Diyanet İlmî Dergi (Diyanet İşleri Reisliği Yıllığı), cilt: LI, sayı: 3, ss. 57-77, Ankara $2015 .^{78}$

35. Mesut Okumuş, "Elmalı1ı M. Hamdi Yazır'ın İlmî Tefsir Anlayışı”, Diyanet İlmî Dergi (Diyanet İşleri Reisliği Yıllığı), cilt: LI, sayı: 3, ss. 79-103, Ankara 2015. ${ }^{79}$

36. İshak Özgel, "Elmalılı Muhammed Hamdi Yazır Tefsirinde Çeviri Etiği ve Teknikleri”, EKEV Akademi Dergisi, y11: XIX, say1: 62, ss. 403-424, (Bahar 2015), Erzurum 2015.

\footnotetext{
${ }^{76} \mathrm{Bu}$ çalışmanın başlığında Elmalılı veya ona ait eserler açıkça belirtilmemiş olsa da araştırmanın içeriğinde Yazır'ın kendi görüşlerine ve içinde bulunduğu devre dair bilgiler bulunmaktadır.

${ }^{77} \mathrm{Bu}$ makale ayrıca Büyük Kur'an Mütefekkiri Elmalılı M. Hamdi Yazır, DİB Yayınları, ss. 55-86, Ankara 2017, 615s. isimli eserin bölümüdür.

${ }^{78}$ Bu makale ayrıca Büyük Kur'an Mütefekkiri Elmalılı M. Hamdi Yazır, DİB Yayınları, ss. 115-138, Ankara 2017, 615s. isimli eserin bölümüdür.

${ }^{79}$ Bu makale ayrıca Büyük Kur'an Mütefekkiri Elmalılı M. Hamdi Yazır, DİB Yayınları, ss. 87-114, Ankara 2017, 615s. isimli eserin bölümüdür.
} 
37. K. Eith, "The mel Trend: The Rising Popularity of Qur'an Translations in Turkey in the 1990s and the Reactions of Turkish Academic Theologians", Journal of Qur'anic Studies, Vol. 17(3), p. 183195. 2015.

38. İsmail Kara, “Üç Devir Üç Hamdi Efendi” Diyânet İlmî Dergi’de cilt: LI, say1: 3, Temmuz-, ss. 1129, (Ağustos-Eylül), Ankara 2015.80

39. Abdurrahman Aydın, "Fahreddin Râzi ile Elmalılı Tefsirleri Bağlamında Nebî, Resûl ve Peygamber Kavramlarına Genel Bir Bakış", Gaziosmanpaşa Üniversitesi İlahiyat Fakültesi Dergisi, cilt: III, say1: 1, ss. 67-84, Tokat 2015.

40. Abdurrahman Altuntaş, "Hasan Basri Çantay’ın "Kur'ân-1 Hakîm ve Meâl-i Kerîm” Adlı Eserinin Başka Meâllerle Mukayesesi, Gümüşhane Üniversitesi İlahiyat Fakültesi Dergisi, cilt: IV, sayı: 7, ss. 17-34, Gümüşhane 2015. ${ }^{81}$

41. Hüseyin Akyüzoğlu, “Elmalıı M. Hamdi Yazır'ın Tefsirde İsrâiliyat Rivayetlerine Yaklaşımı”, EKEV Akademi Dergisi, cilt: XX, say1: 65, ss. 295-311, Erzurum 2016.

42. Necmi Atik, "Elmalılı'nın "Hak Dini Kur'ân Dili” Adlı Tefsiri’nin Mukaddimesi’nin Edisyon Kritiği”, İlahiyat Araştırmaları Dergisi, sayı: 6, ss. 99-131, Ankara 2016.

43. Ahmet Karadağ, "Elmalılı Hamdi Yazır'ın Nesh Anlayışı”, İnönü Üniversitesi İlahiyat Fakültesi Dergisi, cilt: VIII, say1: 1, ss. 149-168, Malatya 2017.

44. Mustafa Ünver, “Tefsirin Temel Bir İlkesi Olarak Siyaka Riayet -Elmalılı Tefsiri Örneği- Tefsir Araştırmaları Dergisi, cilt: I, sayı: 1, ss. 73-120, Sakarya 2017.

45. Mehmet Kaya, Hak Dini Kur'an Dili Tefsirinde Şiirle İstişhâd”, Dinbilimleri Akademik Araştırma Dergisi, cilt: XVII, say1: 1, ss. 9-42, Samsun 2017.

46. Hikmet Koçyiğit, "Günümüz Türkçe Kur'an Meâlleri Üzerine Bir Tasnif Denemesi”, İstanbul Üniversitesi İlahiyat Fakültesi Dergisi, sayı: 37, ss. 79-121, İstanbul 2017.

47. Dilek Uçar, "Elmalılı'da Maneviyat", Sosyal Bilimler Dergisi, Yı1: 5, Sayı: 24, ss. 409-427, (Haziran) Sakarya 2018.

\section{2 İslam Hukuku Alanında Yazılan ve Hakemli Dergilerde Yayımlanan Makaleler}

1. Nazif Öztürk, "M. Hamdi Yazır'ın Vakıfcılık Anlayışı”, İslâmî Araştırmalar Dergisi, cilt: V, sayı: 3, ss. 208-214, (Temmuz) Ankara 1991.

2. Nazif Öztürk, "Elmalı'lı Hamdi Yazır'ın Metrukatı Hakkında”, Din Öğretimi Dergisi, sayı: 30, ss. 37-40, Temmuz-Ağustos Ankara 1992.

3. Ferhat Koca, "Elmalılı M. Hamdi Yazır, Alfabetik İslâm Hukuku ve Fıkıh Istılahları Kamusu, I-V, (nşr. Sıtkı Gülle)", İslâm Araştırmaları Dergisi, sayı: 3, ss. 297-300, İstanbul 1999.

4. Menderes Gürkan, "Elmalılı M. Hamdi Yazır'ın (1878-1942) İlmî Kişiliği ve Fıkıh İlmindeki Yerine Bir Bakış", İslâm Hukuku Araştırmaları Dergisi, sayı: 4, ss. 211-232, (Son Asır İslâm Hukukçuları Özel Sayısı), Konya 2005.

\footnotetext{
${ }^{80}$ Bu makale ayrıca Büyük Kur'an Mütefekkiri Elmalılı M. Hamdi Yazır, DİB Yayınları, ss. 33-53, Ankara 2017, 615s. isimli eserin bölümüdür.

${ }^{81}$ Bu çalışma, 19-21 Eylül 2014 tarihleri arasında Balıkesirecde düzenlenen Vefatının 50. Yılında Hasan Basri Sempozyumu'n da, "Hasan Bari Çantay'ın Meâli ile Diğer Bazı Meâller ((Elmalılı Hamdi Yazır, Ömer Rıza Doğrul, Diyanet Vakıf, Salih Akdemir, Mustafa Öztürk, Yaşar Nuri Öztürk) Arasındaki Farklı Tercüme Tekniklerinin İncelenmesi” adıyla sunulan tebliğin geliştirilmiş halidir
} 
5. Asım Cüneyd Köksal, "Siyaset ve Hukuk Arasında Elmalılı M. Hamdi Yazır'ın Fıkıh Düşüncesi”, İslâm Araştırmaları Dergisi, sayı: 26, ss. 49-79, Ankara 2011.

6. Şevket Topal, "Elmalılı ile Aksekili Arasında Seferilik Hükmü Tartışması”, Recep Tayyip Erdoğan Üniversitesi İlahiyat Fakültesi Dergisi, sayı: 3, ss. 7-29, Rize 2013.

7. Emine Gümüş Böke, "Elmalılı Hamdi Yazır’da Evliliğe Son Veren Terimler Anlayışı”, Diyanet İlmî Dergi, (Diyanet İşleri Reisliği Yıllı̆̆ı) cilt: L, sayı: 3, ss. 31-41, Ankara 2014.

8. Hamdi Çilingir, "Elmalılı Muhammed Hamdi Yazır'ın Gözüyle Osmanlı Son Dönemi Vakıf Meseleleri”, İnsan ve Toplum Dergisi, cilt: 5, say1: 9, ss. 33-47, İstanbul 2015.

9. Abdullah Çolak, "Hak Dini Kur'ân Dili Bağlamında Bir Hukukçu Olarak Elmalı1ı M. Hamdi Yazır", Diyanet İlmî Dergi (Diyanet İşleri Reisliği Yıllığı), cilt: LI, sayı: 3, ss. 131-162, Ankara 2015. ${ }^{82}$

10. Necmi Atik, "Elmalılı'nın Kendi El Yazması ile Türkçe İbadet Konusundaki Makalesi”, İlahiyat Araştırmaları Dergisi, sayı: 6, ss. 1-51, Ankara 2016.

11. Röya Aliyeva, “Kur'an-1 Kerim'in Tercümesi Meselesi ve Meal Tarihi”, Bakü Devlet Üniversitesi İlahiyat Fakültesi İlmi Mecmuas1, say1: 25, s. 231-245, Bakü 2016.

12. Necmi Atik, “Elmalı1ı Muhammed Hamdi Yazır'ın İslam Hukuku Kâmûsu ve Âdem Maddesi’nin Tahlîli", İlahiyat Araştırmaları Dergisi, sayı: 8, ss. 65-98, Karabük 2017.

13. Necmi Atik, "Elmalılı Muhammed Hamdi Yazır'ın Hüccetullâhi'l-Bâliga Tercümesi Üzerine”, İlahiyat Araştırmaları Dergisi, sayı: 8, ss. 23-44, Karabük 2017.

\subsection{Kelam Alanında Yazılan ve Hakemli Dergilerde Yayımlanan Makaleler}

1. Sabri Yılmaz, “Hak Dini Kur'ân Dili’nde Kader İnancı ve İnsan Hayatındaki Yeri”, Dokuz Eylül Üniversitesi İlahiyat Fakültesi Dergisi, sayı: 22, ss. 145-163, İzmir $2006{ }^{83}$

2. Nurullah Kayışoğlu, "Hak Dini Kur'an Dili'nde Fatiha ve Bakara Sûreleri Çerçevesinde Bilgi İman Amel İlişkisi”, Harran Üniversitesi İlahiyat Fakültesi Dergisi, sayı: 31, ss. 85-98, Şanlıurfa 2014.

3. İbrahim Bayram, "Elmalılı Muhammed Hamdi Yazır'ın Mûcizelere Bakışı”, Gaziosmanpaşa Üniversitesi İlahiyat Fakültesi Dergisi, cilt: III, sayı: 2, ss. 77-102, Tokat 2015.

4. İbrahim Coşkun, "Elmalılı Hamdi Yazır'ın Pozitivizme Karşı Dinî Argümanları”, Diyanet İlmî Dergi (Diyanet İşleri Reisliği Yıllığı), cilt: LI, sayı: 3, ss. 203-229, Ankara 2015. ${ }^{84}$

5. Kamil Sarıtaş, "Muhammed Hamdi Yazır'ın Ruh Anlayışı”, Turkish Studies, sayı/volume: 11 Issue 12, ss. 181-204, Ankara 2016.

6. Mustafa Akman, "Kelâmî Perspektifle Elmalı1ı Muhammed Hamdi Yazır", Uluslararası Sosyal Araştırmalar Dergisi, cilt: X, say1: 50, ss. 833-862, Sakarya 2017.

7. Arslan Karaoğlan, "İsrâ ve Mi’râc Hâdisesi Üzerine Bir Giriş Denemesi”, Bilimname, cilt: XXXIV, ss. 555-601, Kayseri 2017.

\footnotetext{
${ }^{82}$ Bu makale ayrıca Büyük Kur'an Mütefekkiri Elmalılı M. Hamdi Yazır, DİB Yayınları, ss. 275-310, Ankara 2017, 615s. isimli eserin bölümüdür.

${ }^{83}$ Ayrıca (“Hak Dini Kur’ân Dili’nde Kader İnancı ve İnsan Hayatındaki Yeri”, İlahiyat Fakülteleri Kelam Anabilim Dalı Sempozyumu 2001, Aktif Yayınları, Erzurum t.y., ss. 171-178.)'da yayımlanmıştır.

${ }^{84}$ Bu makale ayrıca Büyük Kur'an Mütefekkiri Elmalılı M. Hamdi Yazır, DİB Yayınları, ss. 415-445, Ankara 2017, 615s. isimli eserin bölümüdür
} 


\section{4 İslam Felsefesi Alanında Yazılan ve Hakemli Dergilerde Yayımlanan Makaleler}

1. Süleyman Hayri Bolay, "Bir Filozof Müfessir, M. Hamdi Yazır”, Milli Eğitim ve Kültür Dergisi, say1: 15, ss. 20-34, Ankara 1982.

2. Mehmet S. Aydın, "Elmalılı'da Teceddüd Fikri”, Din Öğretimi Dergisi, sayı: 34, ss. 49-54, Ankara 1992.

3. Hatice Toksöz, "Elmalılı Hamdi Yazır'ın İhlas Suresi Tefsirinde Tanrı Tasavvuru ile İlgili Felsefi Kavramlar ve İbn Sina'daki Temelleri", Süleyman Demirel Üniversitesi İlahiyat Fakültesi Dergisi, say1: 28, ss. 39-61, Isparta 2012.

4. Hasan Hüseyin Bircan, "Elmalılı Muhammed Hamdi Yazır'ın Felsefeye Yaklaşımı ve Felsefe Savunusu", Necmettin Erbakan Üniversitesi Sosyal Bilimler Enstitüsü Dergisi, cilt: I, sayı: 1, (Ocak-Haziran), Konya 2015.

5. Hatice Toksöz, "Elmalılı Hamdi Yazır'da Ahlakın Dini Temeli”, Diyanet İlmî Dergi (Diyanet İşleri Reisliği Y1llığı), cilt: LI, say1: 3, ss. 247-272, Ankara 2015. ${ }^{85}$

\subsection{Arap Dili ve Edebiyatı Alanında Yazılan ve Hakemli Dergilerde Yayımlanan Makaleler}

1. Abdulkadir Bayam, "Hak Dini Kur'ân Dili’ndeki Arapça Şiirlerin Temel Kaynaklarla Mukayesesi” (I), Bilimname, cilt: VIII, sayı: 18, ss. 133-166, Kayseri 2010.

2. Abdulkadir Bayam, "Hak Dini Kur’ân Dili’ndeki Arapça Şiirlerin Temel Kaynaklarla Mukayesesi (II)", Bilimname, cilt: VIII, say1: 19, ss. 153-194, Kayseri 2010.

3. Abdulkadir Bayam, “Hak Dini Kur'ân Dili’ndeki Arap Mesellerinin Tespiti ve İncelenmesi”, Dokuz Eylül Üniversitesi İlahiyat Fakültesi Dergisi, cilt: I, sayı: 35, ss. 133-165, İzmir 2012.

4. Abdulkadir Bayam, "Hak Dini Kur'ân Dili’ndeki Arap Mesellerinin Tespiti ve İncelenmesi”, Dokuz Eylül Üniversitesi İlahiyat Fakültesi Dergisi, cilt: II, sayı: 36, ss. 325-355, İzmir 2012.

\subsection{Din Felsefesi Alanında Yazılan ve Hakemli Dergilerde Yayımlanan Makaleler}

1. Recep Kılıç, "Hamdi Yazır'da Din Felsefesi”" Türk Yurdu Dergisi, cilt: XII, sayı: 53, ss. 47-50, İstanbul 1992.

2. Yaşar Türkben, "Elmalılı M. Hamdi Yazır'ın Ölümsüzlüğe Dair Düşünceleri”, Cumhuriyet Üniversitesi İlahiyat Fakültesi Dergisi, cilt: XVI, sayı: 2, ss. 333-363, Sivas 2012.

3. Aliye Çınar Köysüren, "Elmalılı Hamdi Yazır Düşüncesinde Din-Felsefe İlişkisi”, Diyanet İlmî Dergi (Diyanet İşleri Reisliği Y1llığı), cilt: LI, sayı: 3, ss. 231-245, Ankara 2015. ${ }^{86}$

\subsection{Din Ë̆itimi Alanında Yazılan ve Hakemli Dergilerde Yayımlanan Makaleler}

1. Nevzat Yaşar Aşıkoğlu, “M. Hamdi Yazır’ın Terbiye Anlayışı ve Eserlerine Eğitimci Gözüyle Bir Bakış", Din Öğretimi Dergisi, sayı: 31, ss. 63-70, Ankara 1991.

2. İbrahim Gürses, "Elmalılı Tefsirinde İnsan ve Davranışı" Uludağ Üniversitesi İlahiyat Fakültesi Dergisi, cilt: X, say1: 2, ss. 161-167, Bursa 2001.

\footnotetext{
${ }^{85}$ Bu makale ayrıca Büyük Kur'an Mütefekkiri Elmalılı M. Hamdi Yazır, DİB Yayınları, ss. 447-478, Ankara 2017, 615s. isimli eserin bölümüdür.

${ }^{86}$ Bu makale ayrıca Büyük Kur'an Mütefekkiri Elmalılı M. Hamdi Yazır, DİB Yayınları, ss. 479-495, Ankara 2017, 615s. isimli eserin bölümüdür.
} 


\subsection{Hadis Alanında Yazılan ve Hakemli Dergilerde Yayımlanan Makaleler}

1. Sami Şahin, "Hak Dini Kur'ân Dili Adlı Tefsirde Hadis Kullanımı”, Cumhuriyet Üniversitesi İlahiyat Fakültesi Dergisi, cilt: XII, sayı: 1, ss. 147-175, Sivas 2008.

2. Sami Şahin, "Hak Dini Kur'ân Dili Adlı Eserde Elmalılı Hamdi Yazır'ın Hadise Yaklaşımı”, Diyanet İlmî Dergi (Diyanet İşleri Reisliği Yıllığı), cilt: LI, sayı: 3, ss. 105-130, Ankara 2015. ${ }^{87}$

\section{9 İslam Tarihi ve Sanatları Alanında Yazılan ve Hakemli Dergilerde Yayımlanan Makaleler}

1. Necdet Şengün, "Elmalılı Muhammed Hamdi Yazır'ın Hak Dini Kur'ân Dili Adlı Tefsirindeki Türkçe Şiirlerin Değerlendirilmesi”, İSTEM: İslâm, San'at, Tarih, Edebiyat ve Mûsikîsi Dergisi, cilt: V, say1: 9, ss. 163-186, Konya 2007.

2. Feyza Betül Köse, “Hak Dini Kur’an Dili Özelinde Tefsir-Siyer İlişkisi”, KSÜ İlahiyat Fakültesi Dergisi, cilt: XIV, say1: 28, ss. 35-60, K. Maraş 2016.

\subsection{Tasavvuf Alanında Yazılan ve Hakemli Dergilerde Yayımlanan Makaleler}

1. Hüseyin Kurt, "Elmalılı Muhammed Hamdi Yazır'ın Tasavvuf Anlayışı", Diyanet İlmî Dergi (Diyanet İşleri Reisliği Yıllığı), cilt: LI, sayı: 3, ss. 163-202, Ankara 2015. ${ }^{88}$

\subsection{Din Sosyolojisi Alanında Yazılan ve Hakemli Dergilerde Yayımlanan Makaleler}

1. Mustafa Özdemir, "Din-Birey ve Toplum İlişkisi Üzerine (Ünver Günay, Peter Berger, E. M. Hamdi Yazır Örneği)”, Mütefekkir, Aksaray Üniversitesi İslami İlimler Fakültesi Dergisi, cilt: IX, sayı: 7, ss. 9-19, Aksaray 2017.

\subsection{Yeniçă̆ Tarihi Alanında Yazılan ve Hakemli Dergilerde Yayımlanan Makaleler}

1. Özgür Oral, "Elmalılı Muhammed Hamdi Yazır, Modern Türkiye'de Siyasi Düşünce: İslâmcılık", Editör: Yasin Aktay, say1: 1112, ss. 184-200, İstanbul 2004.

\subsection{Dinler Tarihi Alanında Yazılan ve Hakemli Dergilerde Yayımlanan Makaleler}

1. Ahmet Aras, "Elmalılı Hamdi Yazır'ın "Hak Dini Kur'ân Dili” Tefsirinde Hristiyan Mezhepleri ile İlgili Görüşleri", Türk-İ́slâm Medeniyeti Akademik Araştırmalar Dergisi, cilt: VII, sayı: 16, ss. 139152, Konya 2013.

\subsection{Felsefe Alanında Yazılan ve Hakemli Dergilerde Yayımlanan Makaleler}

1. Paul Janet ve Gabriel Seailles, Metâlib ve Mezâhib, Çev: Hamdi Bey (Elmalılı Hamdi Yazır), İstanbul Matbaa-i Âmire, 1339, Tanıtan: Mehmed Emin, Dârülfünun Edebiyat Fakültesi Mecmuası, cilt: III, say1: 2-3, ss. 159-174, İstanbul 1339 (1923).

\section{Elmalılı M. Hamdi Yazır ve Eserleri ile İlgili Hakemsiz Dergilerde ve Gazetelerde Yayımlanan Makaleler}

$\mathrm{Bu}$ çalışmalar herhangi bir hakem sürecinden geçmemiş olsalar da içerikleri incelendiğinde çoğunun akademik değer taşıdıkları görülmektedir.

1. Ömer Riza Doğrul, “Müesssif Bir İrtihal”, 28 Mayıs 1942, Cumhuriyet Gazetesi, İstanbul 1942.

2. “Büyük Türk Âlim Küçük Hamdi’nin Vefatı”, 30 Mayıs 1942, Cumhuriyet Gazetesi, s. 2, İstanbul 1942.

\footnotetext{
${ }^{87}$ Bu makale ayrıca Büyük Kur'an Mütefekkiri Elmalılı M. Hamdi Yazır, DİB Yayınları, ss. 243-273, Ankara 2017, 615s. isimli eserin bölümüdür

${ }^{88}$ Bu makale ayrıca Büyük Kur'an Mütefekkiri Elmalılı M. Hamdi Yazır, DİB Yayınları, ss. 311-357, Ankara 2017, 615s. isimli eserin bölümüdür.
} 
3. Ömer Rıza Doğrul, "Kaybedilen Büyük Âlim Elmalılı Mehmed Hamdi”, 10 Haziran 1942, Cumhuriyet Gazetesi, İstanbul 1942.

4. "Kayıplarımız: Elmalı1ı Küçük Hamdi Hoca”, Temmuz 1942, Millet Gazetesi, s. 42, İstanbul 1942.

5. Muhammed Hamdi Yazır, “Kur'an-1 Kerim Tercüme Edilebilir mi?”, İslâm Dergisi, cilt: I, sayı: 2, ss. 34-35, İstanbul 1956.

6. Muhammed Hamdi Yazır, “Tefsir ve Te'vil”, İslâm Dergisi, cilt: I, sayı: 3, s. 66, İstanbul 1956.

7. Muhammed Hamdi Yazır, "Kur'an Tercümeleri Münasebetiyle”, İslâm Dergisi, cilt. I, sayı: 5, ss. 8-10, İstanbul 1956.

8. Vehbi Vakkasoğlu, Elmalılı Muhammed Hamdi Yazır”, Tercüman Gazetesi, 29 Nisan 1987, İstanbul 1987.

9. Vehbi Vakkasoğlu, Elmalılı Muhammed Hamdi Yazır”, Tercüman Gazetesi, 30 Nisan 1987, İstanbul 1987.

10. Vehbi Vakkasoğlu, Elmalı1ı Muhammed Hamdi Yazır”, Tercüman Gazetesi, 1 Mayıs 1987, İstanbul 1987.

11. Vehbi Vakkasoğlu, Elmalılı Muhammed Hamdi Yazır”, Tercüman Gazetesi, 2 Mayıs 1987, İstanbul 1987.

12. "Elmalı11 M. Hamdi” Diyanet Aylık Dergi, sayı: 10, s. 49, (Ekim) Ankara 1991.

13. Fatma Paksüt, "Merhum Dayım Hamdi Yazır I", Altınoluk Dergisi, sayı: 74, ss. 20-23, İstanbul 1992.

14. Fatma Paksüt, "Merhum Dayım Hamdi Yazır II”, Altınoluk Dergisi, sayı: 75, ss. 21-22, İstanbul 1992.

15. Fatma Paksüt, "Biz Neyiz”, Altınoluk Dergisi, say1: 75, s. 23, İstanbul 1992.

16. Fatma Paksüt, "Merhum Dayım Hamdi Yazır III”, Altınoluk Dergisi, sayı: 76, ss. 42-44, İstanbul 1992.

17. Hüsrev Subaşı, "Elmalılı Hamdi Efendi ve Hat Sanatımızdaki Yeri”, İlim ve Sanat Dergisi, sayı: 33, ss. 18-26, Ankara 1992.

18. Zahid Erdem, "Bilinmeyen Yönleriyle Elmalılı M. Hamdi Yazır'ı Anma Programı'ndan Notlar", İlim ve Sanat Dergisi, sayı: 34, ss. 71-73, Ankara 1993.

19. Suat Yıldırım, "Elmalı1ı Hamdi Yazır ve Tefsiri”, Yeni Ümit Dergisi, sayı: 20, Y11: 5, İzmir 1993.

20. Hüseyin Algül, "Hak Dini Kur'ân Dili Tefsirinde İslâm Tarihi Dokümanlarının Değerlendirilişi”, Yeni Ümit Dergisi, say1: 24, (Nisan-Haziran 1994), İzmir 1994.

21. Süleyman Hayri Bolay, "Müfessir Olarak Elmalılı Muhammed Hamdi Yazır”, 17 Eylül 1994, Yeni Asya Gazetesi, Y11: 25, say1: 8753, s. 2, İstanbul 1994.

22. Fahri Atasoy, "Elmalılı Muhammed Hamdi Yazır", Türk Yurdu Dergisi, Y11: 24, sayı: 81, ss. 63 64, Ankara 1994.

23. Dücane Cündioğlu, "Elmalılı Tefsirinin Mevcut Nüshalarına Güvenilemez”, 28 Ekim 1998,Yeni Şafak Gazetesi, s. 13, İstanbul 1998.

24. Dücane Cündioğlu, "Elmalılı Tefsiri Şaibe Altında Bırakılmamalı”, 29 Ekim 1998, Yeni Şafak Gazetesi, s. 13, İstanbul 1998. 
25. Dücane Cündioğlu, “Tarihe Kayıt Düşmek: Elmalılı Tefsiri”, 31 Ekim 1998, Yeni Şafak Gazetesi, s. 13, İstanbul 1998.

26. Güngör Özyiğit, “Kur'ân'1 Türkçe’ye İlk Çeviren ve Yorumlayan Elmalılı Hamdi Yazır” Sevgi Dünyas1 Dergisi, say1: 353, ss. 10-16, (Mart) İstanbul 1998.

27. Güngör Özyiğit, "Elmalılı Hamdi Yazır’ın Bir Gazeli”, Sevgi Dünyası Dergisi, sayı: 353, ss. 11-14, (May1s) İstanbul 1998.

28. Dücane Cündioğlu, "Elmalı1ı Hamdi Yazır'ın Şahsî Kütüphanesi”, 12 Aralık 1998, Yeni Şafak Gazetesi, s. 13, İstanbul 1998.

29. Zafer Öge, "Elmalılı Muhammed Hamdi Yazır'ın Eğitim (Terbiye) Anlayışı ve Eserlerinin Eğitim Özellikleri”, Mehir Dergisi, say1: 4, ss. 56-65, Konya 1999.

30. Ramazan Özalpdemir, "Elmalı1ı Muhammed Hamdi Yazır”, Diyanet Aylık Dergi, sayı: 101, ss. 63 66, Ankara 1999.

31. Yusuf Kol, "Elmalı1ı Hamdi Yazır”, Diyanet Aylık Dergi, sayı: 125, ss. 68-69, Ankara 2001.

32. "Kaht-1 Ricâl Ortamında Bir İlim Deryası Elmalı1ı Muhammed Hamdi Yazır", Altınoluk, Y11: 17, say1: 195 s. 45, (Mayı) İstanbul 2002.

33. İsmail Albayrak, "Elmalı1ı Muhammed Hamdi Yazır ve Bediuzzaman Said Nursi'nin Nesh Konusuna Yaklaşımı", Yeni Ümit Dergisi, sayı: 64, ss. 36-42, (Nisan-Mayıs-Haziran) İzmir 2004.

34. Süleyman Hayri Bolay, "M. Hamdi Yazır ve Ucub”, Altınoluk Dergisi, Yı1: 21, sayı: 253, s. 24-25, (Mart) İstanbul 2007.

35. Suat Yıldırım, "Elmalılı M. Hamdi Yazır'ın Müteşâbih Ayetleri Anlamaya Katkısı", Yeni Ümit Dergisi, say1: 78, yıl: 18, ss. 5-9, İzmir 2007.

36. Mesut Kaya, "Sadece Tefsir Değil, Bir İlim Hazinesi”, Genç Dergisi, s. 13, (Ekim) İstanbul 2007.

37. Tahsin Görgün, "İlmî Geleneğimiz ve Elmalılı”, İLEM Yıllık, Yı1: 3, ss. 9-17, İstanbul 2008.

38. Ahmet Faruk Güney, "İbn Sina'dan Elmalılı'ya İhlâs Sûresi Felsefî Tefsir Geleneği”, Değerlendirme: Hüseyin Aygün, Bilim Sanat Vakfı Bülteni, sayı: 70, ss. 42-44, (Mayıs-Ağustos), İstanbul 2009.

39. Suat Yıldırım, “Elmalılı’nın Meâli veya Sahipsizliğin Meâli”, Yeni Ümit Dergisi, sayı: 84, (NisanMayıs-Haziran) İzmir 2009.

40. "Elmalılı Muhammed Hamdi Yazır (1878-1942)”, TDV Haber Bülteni, sayı: 101, ss. 76-78, (NisanMayıs-Haziran) Ankara 2010.

41. "Elmalılı Hamdi Yazır'ın Makaleleri Kitaplaştı”, Mostar Dergisi, sayı: 130, s. 74, (Ekim) İstanbul 2011.

42. "Elmalı1ı Hamdi Bir Öykü Kahramanı Olursa", Dil ve Edebiyat Dergisi, sayı: 90, s. 9, (Nisan) Ankara 2012.

43. Muhittin Akgül, "Şaheser Bir Tük Müellif: Elmalılı M. Hamdi Yazır”, Sızıntı Dergisi, sayı: 412, İzmir 2013.

44. "Elif Arslan, Bekâ İçinde Yenilenme, Yenilenme İçinde Bekâ, Elmalı1ı Muhammed Hamdi Yazır (1878-1942), Diyanet Aylık Dergi, say1: 278, ss. 38-40, (Şubat) Ankara 2014. 


\section{F. Ansiklopedi Maddeleri}

1. "İslâm Âlemi İçin Büyük Bir Ziyâ: Elmalı1ı M. Hamdi Efendinin Vefatı", İslam-Türk Ansiklopedisi, Mûhîtülmeaarif, cilt: I, 15 Haziran 1942/30, Cemâziyelevvel 1361, No: 36, İstanbul 1942.

2. Yusuf Şevki Yavuz, "Elmalı1ı Muhammed Hamdi Yazır", DIA, TDV Yayınları, c. XI, ss. 57-62, İstanbul 1995.

3. Mustafa Bilgin, “Hak Dini Kur'an Dili”, DİA, TDV Yayınları, c. XV, ss. 153-163, İstanbul 1997.

4. İhsan Işık, "Elmalılı Muhammed Hamdi (Yazır)" Türkiye Edebiyat ve Kültür Adamları Ansiklopedisi, Elvan Yayınları, c. III, ss. 1167-1169, Ankara 2006.

\section{G. EImalılı M. Hamdi Yazır ve Eserleri ile İlgili Sempozyumlar:}

\section{EImalılı M. Hamdi Yazır Hakkında Yapılan Sempozyum Bildirileri}

Elmalılı M. Hamdi Yazır'ın doğum yeri olan Antalya/Elmalı'da 4-6 Eylül 1991 tarihleri arasında Türkiye Diyanet Vakfı tarafından sempozyum yapılmış Elmalılı'nın eserleri ve fikirleri değişik yönleriyle tartışılmıştır. Sempozyum bildirileri TDV tarafindan Elmalılı Muhammed Hamdi Yazır ${ }^{89}$ adıyla kitap olarak basılmıştır. Bu sempozyum bildirilerini şöyle sıralayabiliriz.

\subsection{Elmalılı M. Hamdi Yazır Sempozyumu, 4-6 Eylül 1991, Antalya/Elmalı}

\subsubsection{Tefsir Alanında Sunulan Sempozyum Bildirileri}

1. Fatma Paksüt, "Merhum Dayım Hamdi Yazır", ss. 2-24. ${ }^{90}$

2. Nesimi Yazıcı, "Muhammed Hamdi Yazır'ın Basın Hayatı ve Yazarlığı”, ss. 25-32.

3. Ali Yılmaz, "Elmalı1ı Hamdi Yazır'ın Türkçesi”, ss. 33-44.

4. Halis Albayrak, "Elmalılı M. Hamdi Yazır'ın Tefsir Anlayışı”, ss. 152-168.

5. İsmet Ersöz, "Elmalılı Hamdi Yazır ve Tefsirinin Özellikleri”, ss. 169-177.

6. Halis Albayrak, “Elmalılı Hamdi Yazır’a Göre Kur’ân'da Din Kavramı”, ss. 281-289.

\subsection{2 İslam Felsefesi Alanında Sunulan Sempozyum Bildirileri}

1. Mehmet Emin (Erişirgil), "İki Eser-i Felsefi Münasebetiyle”, Sadeleştiren: Recep Kılıç, ss. 45-48.

2. Recep Kılıç, "Elmalılı Muhammed Hamdi Yazır”, "Dibace (Önsöz)”, (Sadeleştirme), ss. 49-84.

3. Süleyman Hayri Bolay, "Bir Filozof Müfessir", ss.125-139.91

4. Tahsin Görgün, “Hamdi Yazır’ın Sosyal Felsefesine Giriş”, ss. 210-220.

5. Hüseyin Aydın, "Bir Mütefekkir Olarak M. Hamdi Yazır”, ss. 260-264.

6. Tahsin Görgün, “Hamdi Yazır'ın Bilgi Teorisi”, ss. 306-316.

\subsection{3 İslam Hukuku Alanında Sunulan Sempozyum Bildirileri}

1. İbrahim Kafi Dönmez, “Hamdi Yazır’ın Fıkıh Usûlü Anlayışı”, ss. 179-186.

\footnotetext{
${ }^{89}$ Elmalılı Muhammed Hamdi Yazır, TDV Yayınları, Ankara 1993, 338s.

${ }^{90}$ Bu bildiri ayrıca ("Merhum Dayım Hamdi Yazır I", Altınoluk Dergisi, sayı: 74, ss. 20-23, İstanbul 1992), "Merhum Dayım Hamdi Yazır II", Altınoluk Dergisi, sayı: 75, ss. 21-22, İstanbul 1992 ve "Merhum Dayım Hamdi Yazır III", Altınoluk Dergisi, sayı: 76, ss. 42-44, İstanbul 1992'de yayımlanmıştır.

${ }_{91} \mathrm{Bu}$ bildiri daha önce "Bir Filozof Müfessir, M. Hamdi Yazır", Milli Eğitim ve Kültür Dergisi, sayı: 15, ss. 20-34, Ankara 1982'de yayımlanmıştır.
} 
2. İbrahim Çalışkan, “Muhammed Hamdi Yazır'ın Hukukçuluğu”, ss. 187-196.

3. Nazif Öztürk, “M. Hamdi Yazır'ın Vakıfcılık Anlayışı”, ss. 197-208.92

4. Nazif Öztürk, “Elmalı1ı M. Hamdi Yazır’ın Metrukâtı Hakkında Ön Rapor”, ss. 335-338.

\subsection{4 İslam Tarihi ve Sanatları Alanında Sunulan Sempozyum Bildirileri}

1. Hüseyin Algül, "Hak Dini Kur’ân Dili Tefsirinde İslâm Tarihi Dokümanlarının Değerlendirilişi”, ss. $221-230 .{ }^{93}$

2. İsmail Kara, "Elmal11 Hamdi Efendi ve Halifelik", ss. 253-258. ${ }^{94}$

3. Hüsrev Subaşı, "Elmalı1ı Hamdi Efendi ve Hat Sanatımızdaki Yeri”, ss. 318-330.95

4. Muhsin Macit, “Elmal11ı Hamdi Yazır'ın Bir Gazeli Etrafinda”, ss. 331-334.

\subsubsection{Din Felsefesi Alanında Sunulan Sempozyum Bildirileri}

1. Recep K1lı̧, "Hamdi Yazır' da Din Felsefesi”, ss. 290-298. ${ }^{96}$

2. Mehmet S. Aydın, “Elmalılı'da Teceddüd Fikri”, ss. 299-305.97

\subsubsection{Tasavvuf Alanında Sunulan Sempozyum Bildirileri}

1. Mustafa Kara, “Hak Dini Kur’ân Dili'nde Tasavvuf Kültürü Üzerine-Hiradan Viyana’ya Bir Çizgi”, ss. 231-240.

\subsubsection{Mezhepler Tarihi Alanında Sunulan Sempozyum Bildirileri}

1. Hasan Onat, “Elmalılı Hamdi Yazır'ın Anlayışı ve Mezheplere Bakışı”, ss. 140-151.

\subsubsection{Din Ë̆itimi Alanında Sunulan Sempozyum Bildirileri}

1. Nevzat Yaşar Aşıkoğlu, “M. Hamdi Yazır’ın Terbiye Anlayışı ve Eserlerine Eğitimci Gözüyle Bir Bakış", ss. 245-252.98

\subsubsection{Din Sosyolojisi Alanında Sunulan Sempozyum Bildirileri}

1. Münir Koştaş, “M. Hamdi Yazır’ın İçtimâî Görüşleri”, ss. 241-244.

\subsubsection{Kelam Alanında Sunulan Sempozyum Bildirileri}

1. Ahmet Akbulut, "Muhammed Hamdi Yazır’da Kelâmî Problemler”, ss. 265-208.

\subsection{Elmalılı M. Hamdi Yazır Sempozyumu, 2-4 Kasım 2012, Antalya.}

Elmalılı M. Hamdi Yazır ile ilgili 2-4 Kasım 2012 tarihinde Akdeniz Üniversitesi İlahiyat Fakültesi tarafından Antalya'da bir sempozyum daha yapılmış ve Elmalılı M. Hamdi Yazır çeşitli yönlerden ele alınarak incelenmiştir. Sempozyumda sunulan bildiriler şunlardır:

\footnotetext{
${ }^{92} \mathrm{Bu}$ bildiri daha önce “M. Hamdi Yazır'ın Vakıfcılık Anlayışı”, İslâmî Araştırmalar Dergisi, cilt: V, sayı: 3, ss. 208-214, (Temmuz) Ankara 1991)'de yayımlanmıştır.

${ }^{93}$ Bu bildiri ayrıca Yeni Ümit Dergisi, sayı: 24, (Nisan-Haziran 1994), İzmir 1994'de yayımlanmıştır.

${ }^{94} \mathrm{Bu}$ bildiri ayrıca (İsmail Kara, "Elmalılı Hamdi Efendi ve Halifelik", Türkiye'de İslamcıllk Düşüncesi, Dergah Yayınları, ss. 463-513, İstanbul 2011, 1174s.) isimli kitabın bölümüdür.

${ }_{95} \mathrm{Bu}$ bildiri ayrıca "Elmalılı Hamdi Efendi ve Hat Sanatımızdaki Yeri”, İlim ve Sanat Dergisi, say1: 33, ss. 18-26, Ankara 1992'de yayımlanmıştır.

${ }^{96} \mathrm{Bu}$ bildiri ayrıca "Hamdi Yazır'da Din Felsefesi” Türk Yurdu Dergisi, cilt: XII, say1: 53, ss. 47-50, İstanbul 1992'de yayımlanmıştır.

${ }^{97}$ Bu bildiri ayrıca Din Öğretimi Dergisi, Ankara 1992, sayı: 34, ss. 49-54'de yayımlanmıştır.

${ }^{98} \mathrm{Bu}$ bildiri ayrıca “M. Hamdi Yazır'ın Terbiye Anlayışı ve Eserlerine Eğitimci Gözüyle Bir Bakış”, Din Öğretimi Dergisi, sayı: 31, ss. 63-70, Ankara 1991)'de yayımlanmıştır.
} 


\subsubsection{Tefsir Alanında Sunulan Sempozyum Bildirileri}

1. İbrahim Hilmi Karslı, "Tefsirî (Anlam Merkezli) Tercüme Açısından M. Hamdi Yazır'ın Meâl Tarzı", ss. 39-69.

2. Veysel Güllüce, "Elmalı1ı M. Hamdi Yazır'ın Kevnî Ayetlere Yaklaşımı ve Bilimsel Tefsirdeki Yeri”, ss. 71-89.

3. İsmail Çalışkan, "Elmalıı Hamdi Yazır M. Abduh'a Neden Kızdı? Bilgi Çağında Bir Bilgin Müfessirin Bilimsel Tefsir Nosyonu", ss. 91-119. ${ }^{99}$

4. Eyüp Yaka, "Müşkil Âyetler Konusunda İbn Kuteybe-Elmalılı Hamdi Yazır Karşılaştırması", ss. 121-176.

5. Erdoğan Pazarbaş1, "Elmalılı Tefsirinden İşâ̂î Yorumlar”, ss. 177-186.

6. Kamil Önal, "Hak Dîni Kur’ân Dili Tefsirinde Dil Unsuru Bakımından Söz Sanatları”. 100

7. Mahmut Öztürk, "Hak Dini Kur’ân Dili’nde Dil Devriminin İzleri”. ${ }^{101}$

8. H. Yunus Apaydın, “Elmalılı Hamdi Yazır'da Te’vil ve Tefsir Terimleri”, ss. 189-199.

\subsubsection{Din Felsefesi Alanında Sunulan Sempozyum Bildirileri}

1. İbrahim Coşkun, “Modern Çağda Dine Yöneltilen Eleştiriler ve M. Hamdi Yazır'ın İslâm İnançlarını Savunusu", ss. 341-368.

2. Ali Kozan, "Bir Türk-İslâm Mütefekkiri: M. Hamdi Yazır ve Siyaset Felsefesi”, ss. 371-391.

3. Ahmet Murat Özel, “ Batı'nın Fikrî Meydan Okumaları Bağlamında Elmalı1ı M. Hamdi Yazır’da Üç Terim: Akıl, Bilgi, Felsefe”, ss. 443-468.

4. Hatice Toksöz, "Elmalılı Hamdi Yazır'ın İhlâs Sûresi Tefsirinde Tanrı Tasavvuru İle İlgili Felsefî Kavramlar ve İbn Sinâ'daki Temelleri”, ss. 469-497.

5. Yaşar Türkben, “Elmalılı M. Hamdi Yazır'ın Ölümsüzlüğe Dair Düşüncelerinin Din Felsefesi Açısından Değerlendirilmesi”, ss. 499-515.

6. Fulya İbanoğlu, "Mevcudu Muhafaza Ederek Terakkî Etmek: Bir II. Meşrutiyet Münevveri Olarak Elmalılı Hamdi Efendi'de Terakkî Fikri”, ss. 517-526.

7. Hüseyin Yılmaz, "Din-Siyaset ilişkisi Bağlamında Muhammed Hamdi Yazır'ın Siyasetçiliği”. ${ }^{102}$

8. Ali Kürşat Turgut, “Elmalılı M. Hamdi Yazır'ın Nefs-Ruh Hakkındaki Görüşleri”’ ss. 695-710. ${ }^{103}$

\subsection{3 İslam Tarihi ve Sanatları Alanında Sunulan Sempozyum Bildirileri}

1. İsmail Kara, "Üç Dönem Üç Elmalı1ı Hamdi”104, ss. 21-35.

2. Şefaettin Severcan, "Evrensel Hilâfetten Millî Hilâfete: Elmalılı M. Hamdi Yazır”, ss. 393-415.

3. Recep Çiğdem, "Elmalılı Hamdi Yazır ve Sultan Abdülhamid'in Hal'i”, ss. 417-440.

\footnotetext{
99 Bu bildiri (2-4 Kasım 2012, Antalya, Elmalılı M. Hamdi Yazır Sempozyumu)'ndaki bildirinin bazı ilavelerle gözden geçirilmiş hali olup ayrıca Büyük Kur'an Mütefekkiri Elmalılı M. Hamdi Yazır, DİB Yayınları, ss. 551-585, Ankara 2017, 615s. isimli eserin bölümüdür.

${ }^{100} \mathrm{Bu}$ bildiri sempozyum programında yer aldığı halde sempozyum kitabına alınmamıştır.

${ }^{101} \mathrm{Bu}$ bildiri sempozyum programında yer aldığı halde sempozyum kitabına alınmamıştır.

$102 \mathrm{Bu}$ bildiri sempozyum programında yer aldığı halde sempozyum kitabına alınmamıştır.

${ }^{103} \mathrm{Bu}$ bildiri sempozyumda bildiri olarak sunulmamış ancak sempozyum kitabına alınmıştır.

${ }^{104}$ Bu bildiri, "Üç Devir Üç Hamdi Efendi” başlığıyla Diyanet İlmî Dergi'de cilt: LI, sayı: 3, Temmuz-Ağustos-Eylül 2015, ss. 11-29' da yayımlanmıştır.
} 
4. Ramazan Şahan, “Elmalılı M. Hamdi Yazır’ın Edebî Kişiliği ve Girmişiz Çıkmışız Redifli Şiirinin Âyetler Işı̆̆ında Değerlendirilmesi”, ss. 547-606.

5. Necmi Atik, “Elmalılı M. Hamdi Yazır'ın Sanat Anlayışı ve Hattatlı̆̆ı”, ss. 607-630.

\subsection{4 İslam Hukuku Alanında Sunulan Sempozyum Bildirileri}

1. Abdullah Çolak, "Bir Hukukçu Olarak Elmalılı M. Hamdi Yazır” ss. 201-229. ${ }^{105}$

2. Abdullah Kahraman, "Elmalı11 M. Hamdi Yazır'ın Mecelle Müdafaası”, ss. 231-264.

3. Merter Rahmi Telkenaroğlu, “M. Hamdi Yazır'da Reforma Karşı Tecdîd ya da Başkalaşmadan Yenileşme Tasavvuru", ss. 265-288.

4. Şevket Topal, “Elmalılı M. Hamdi Yazır İle Aksekili Ahmed Hamdi’nin Seferîlik Hükümlerine Dair Görüşlerinin Ezmânın Tagayyürüyle Ahkâmın Tagayyürü İnkâr Edilemez F1kıh Kaidesi Çerçevesinde Analizi", ss. 289-308.

5. Mehmet Eren, “Elmalılı'nın Huccetullâhi'1-Bâliğa'dan Tercüme Ettiği Yazı Üzerine Bazı Mülahazalar", ss. 633-650. ${ }^{106}$

\subsubsection{Kelam Alanında Sunulan Sempozyum Bildirileri}

1. Mahmut Çınar, "Elmalılı M. Hamdi Yazır'ın Nübüvvet Anlayışı”, ss. 311-322.

2. Bünyamin Erul, “Hak Dîni Kur’ân Dili’nde Hz. Muhammed Tasavvuru”, 323-340.

\subsubsection{Dinler Tarihi Alanında Sunulan Sempozyum Bildirileri}

1. Ahmet Aras, "Elmalıı M. Hamdi Yazır'ın Hıristiyanlıkla İlgili Bilgilerinin Değerlendirilmesi”, ss. 527-544.

\subsubsection{Hadis Alanında Sunulan Sempozyum Bildirileri}

1. Veli Atmaca, "Elmalı1ı Tefsiri’nde Mevzû Sayılan Rivâyetler ve Mevzû Hadis Meselesine Dair Bazı Mülahazalar" ss. 651-693. ${ }^{107}$

\subsubsection{Tasavvuf Alanında Sunulan Sempozyum Bildirileri}

1. Hüseyin Kurt, “Elmalı1ı M. Hamdi Yazır'ın Tevhid ve Vahdet-i Vücûd Anlayışı”. ${ }^{108}$

\subsubsection{Mezhepler Tarihi Alanında Sunulan Sempozyum Bildirileri}

1. Mehmet Dalkılıç, “Elmalılı M. Hamdi Yazır’ın Mezhep Algısı Bağlamında Şiîlik Eleștirisi”. ${ }^{109}$

\section{Diğer Sempozyumlar}

Elmalı1ı M. Hamdi Yazır üzerine yapılan bu iki sempozyum dışında başka sempozyumlarda da çeşitli bildiriler sunulmuştur. Tespit edebildiğimiz tebliğleri şöyle sıralayabiliriz:

\footnotetext{
${ }^{105}$ Bu bildiri ayrıca "Hak Dini Kur'ân Dili Bağlamında Bir Hukukçu Olarak Elmalılı M. Hamdi Yazır=Elmalılı Hamdi Yazır as a Jurist in the Context of "Hak Dini Kuran Dili”, Diyanet İlmî Dergi (Diyanet İşleri Reisliği Yıllığı), cilt: LI, sayı: 3, ss. 131162, Ankara 2015'de yayımlanmıştır.

${ }^{106} \mathrm{Bu}$ bildiri sempozyumda bildiri olarak sunulmamış ancak sempozyum kitabına alınmıştır.

${ }^{107} \mathrm{Bu}$ bildiri sempozyumda bildiri olarak sunulmamış ancak sempozyum kitabına alınan bildiridir.

${ }^{108} \mathrm{Bu}$ bildiri sempozyum programında yer aldığı halde sempozyum kitabına alınmamıştır. Bu bildirinin aynı yazara ait bir makalede kısmen yer aldığı söylenebilir. Bkz. Hüseyin Kurt, "Elmalılı Muhammed Hamdi Yazır'ın Tasavvuf Anlayışı=Sufism Understanding of Elmalılı Muhammed Hamdi Yazır”, Diyanet İlmî Dergi (Diyanet İşleri Reisliği Yıllığı), cilt: LI, sayı: 3, ss. 163-202, Ankara 2015.

${ }^{109} \mathrm{Bu}$ bildiri sempozyum programında yer aldığı halde sempozyum kitabına alınmamıştır.
} 


\subsection{Tefsir Alanında Sunulan Sempozyum Bildirileri}

1. Mustafa Akçay, "M. Esed'in "Sünnetullah, Fitratullah, Sibğatullah, Bezm-i Elest (Misak) ve Fetret" Kavramlarını Anlamlandııışı ve M. Hamdi Yazır ile Rıza Doğrul Meâlleriyle Karşılaştırılması”, Kur'ân Meâlleri Sempozyumu -Eleștiriler ve Öneriler- (24-26 Nisan 2003, İzmir), cilt: I, ss. 349384, Ankara 2007.

2. İbrahim Hilmi Karslı, "Çeviri Kuramları Açısından M. Hamdi Yazır'ın Çeviri Yöntemi”, Kur’ân Meâlleri Sempozyumu -Eleștiriler ve Öneriler- (24-26 Nisan 2003, İzmir), cilt: II, ss. 41-68, Ankara $2007 . .^{110}$

3. Murat Kaya, "Tanzimat Sonrasındaki Tefsir Faaliyetleri”, Başlangıçtan Günümüze Türklerin Kur'an Tefsirine Hizmetleri -Tebliğler ve Müzakereler- Tartışmalı İlmi Toplantı 21-22 Ekim 2011, ss. 301-338, Ensar Neşriyat, İstanbul 2012.

4. Sadrettin Gümüş, “Kur'an ve Tefsir'in Türkçeye Çevirisinin Tarihi Süreci”, Başlangıçtan Günümüze Türklerin Kur'an Tefsirine Hizmetleri -Tebliğler ve Müzakereler- Tartışmalı İlmi Toplant1, 21-22 Ekim 2011, ss. 25-40, Ensar Neşriyat, İstanbul 2012.

5. Muhittin Akgül, “Anlaşılır Olması Açısından M. Akif Ersoy’un Meali ve Elmalı'yla Mukayesesi”, Direnen Meal Akif Meali Uluslararas1 Sempozyum, (6-7 Nisan 2013), İstanbul 2013. ${ }^{111}$

6. Abdurrahman Altuntaş, "Hasan Bari Çantay'ın Meâli ile Diğer Bazı Meâller (Elmalılı Hamdi Yazır, Ömer Rıza Doğrul, Diyanet Vakıf, Salih Akdemir, Mustafa Öztürk, Yaşar Nuri Öztürk)" Vefatının 50. Y1lında Hasan Basri Sempozyumu, (19-21 Eylül 2014), Balıkesir 2014. ${ }^{112}$

7. Bilal Deliser, "Hak Dini Kur'an Dili’nde İsa-Mesih ve Mehdilikle İlgili Görüşler”, (29-30 Eylül 2017), Uluslararas1 Mehdilik Sempozyumu Bildirileri, ss. 305-334, Sivas 2018.

\subsection{Hadis Alanında Sunulan Sempozyum Bildirileri}

1. Recep Bilgin, “Hak Dini Kur'an Dili Tefsirinin Hadis Kaynakları”, 10. Uluslararası Sosyal Bilimler ve Spor Kongresi, (23-25 Kasim 2018), Hatay 2018.

2. Recep Bilgin, "Bir Literatür İncelemesi; Elmalı11 M. Hamdi Yazır (1878-1942) ve Hak Dini Kur'an Dili Adlı Tefsiri Hakkında Hadis Alanında Yapılan Çalışmalar", 10. Uluslararası Sosyal Bilimler ve Spor Kongresi, (23-25 Kasım 2018), Hatay 2018.

\subsection{Kelam Alaninda Sunulan Sempozyum Bildirileri}

1. Sabri Yılmaz, “Hak Dini Kur’ân Dili’nde Kader İnancı ve İnsan Hayatındaki Yeri”, Günümüz İnanç Problemleri İlahiyat Fakülteleri Kelam Anabilim Dalı Sempozyumu 2001, ss. 171-178, Aktif Yayınları, Erzurum t.y..

\footnotetext{
${ }^{110} \mathrm{Bu}$ bildiri ayrıca Cumhuriyet Üniversitesi İlahiyat Fakültesi Dergisi, cilt: IX, say1: 1, ss. 231-255, Sivas 2005'de yayımlanmıştır.

${ }^{111}$ Sempozyum bildirileri kitap olarak da basılmıștır. Muhittin Akgül, “Anlaşılır Olması Açısından M.Akif Ersoy’un Meali ve Elmalı'yla Mukayesesi”, Direnen Meal Akif Meali Editör: Recep Şentürk, Yayına Hazırlayan: Vahdettin Iş̧k. ss. 137-160, Mahya Yayınları, İstanbul 2016, 220s.

112 Abdurrahman Altuntaş, "Hasan Basri Çantay'ın "Kur'ân-1 Hakîm ve Meâl-i Kerîm” Adlı Eserinin Başka Meâllerle Mukayesesi, Gümüşhane Üniversitesi İlahiyat Fakültesi Dergisi, 2015, cilt: IV, sayı: 7, ss. 17-34. Bu çalışma, 19-21 Eylül 2014 tarihleri arasında Balıkesir"ede düzenlenen Vefatının 50. Yılında Hasan Basri Sempozyumu'nda, "Hasan Bari Çantay'ın Meâli ile Diğer Bazı Meâller ((Elmalılı Hamdi Yazır, Ömer Rıza Doğrul, Diyanet Vakıf, Salih Akdemir, Mustafa Öztürk, Yaşar Nuri Öztürk) Arasındaki Farklı Tercüme Tekniklerinin İncelenmesi” adıyla sunulan tebliğin geliştirilmiş halidir
} 
2. M. Hanefi Palabıyık-Nur Gökhan-Rabia Olçar, "Elmalılı Muhammed Hamdi Yazır'ın Hz. Peygamber Algısı, Medrese ve İlahiyat Kavşağında İslâmî İlimler", (Uluslararası Sempozyum) 29 Haziran-1 Temmuz 2012, cilt: II, ss. 319-356, İstanbul 2013.

\section{4 İslam Felsefesi Alanında Sunulan Sempozyum Bildirileri}

1. Mustafa Gündüz, "Elmalılı Muhammed Hamdi'nin Çağdaş Türk Düşüncesindeki Yeri ve Önemi Üzerine Bazı Düşünceler", 20. yüzyılda Antalya Sempozyumu (22-24 Kasım 2007, Antalya) Sempozyum Bildirileri, cilt: II, ss. 621-635, Antalya 2008.

2. Susan Gunasti, "Philosophy as Methodology: Elmalılı Muhammed Hamdi Yazır's Spiritualism and Religious Reform in the Late Ottoman Empire", Refonners and Intellectual Refonnulationin Contemporary Islam (29-30 January) London 2015. (Yayın bilgisine ulaşılamamıştır.)

\section{5 İslam Hukuku Alanında Sunulan Sempozyum Bildirileri}

1. Beşir Gözübenli, “Elmalııı Hamdi Yazır'ın Seferilik Konusuna Yaklaşımı, Seferilik ve Hükümler”, İSAV Tartışmalı İlmî Toplantılar Dizisi, ss. 137-152, İstanbul 1997.

\subsection{Tarih Alanında Sunulan Sempozyum Bildirileri}

1. Ali Kozan, "Sultan Abdülhamid'in Hal'inde Bir İslâm Âlimi: Elmalılı Hamdi Yazır", Sultan II. Abdülhamid Sempozyumu (20-21 Şubat 2014, Selanik), Atatürk Kültür Dil ve Tarih Yüksek Kurumu, cilt: I, ss. 233-242, Ankara 2014.

\subsection{Din Felsefesi Alantnda Sunulan Sempozyum Bildirileri}

1. Ahmet T. Karamustafa, "Yeni Bir Din Felsefesi Arayışı ve Elmalılı Hamdi Yazır", Osmanlı Devleti'nde Din ve Vicdan Hürriyeti", Milletlerarası Tartışmalı Ilmi Toplantı (Kasım 1999, Ístanbul), Ensar Neşriyat, ss. 289-295, İstanbul 2000.

\section{H. Elmalıı M. Hamdi Yazır Hakkında Yabancı Dillerde Yazılmış, Kitap, Kitap Bölümü, Makale ve Tezler.}

\section{Kitap;}

1. Benjamin Flöhr, Ein traditionalistischer Korandeuter im Dienste des Kemalismus: Elmalili Muhammed Hamdi Yazir (1878-1942), Klaus Schwarz Verlag/(Islamkundliche Untersuchungen; Bd. 326.) Berlin, 2015, 561s.

\section{Kitap Bölümü;}

1. Ursula Ragacs, "Elmalı1ı (1878-1942)" Religion übersetzen: Übersetzung und Textrezeption als transformation sphänomene von Religion, Grohmann, Marianne; Appel, Kurt; Danz, Christian; Potz, Richard; Rosenberger, Sieglinde; Walser, Angelika vd. Gottingen: Vandenhoeck \& Ruprecht 2012, ss. 212-213.

2. Ahmet Şeyhun, "Chapter 13 Elmalili Hamdi Yazir (1878-1942)" Islamist Thinkers in the Late Ottoman Empire and Early Turkish Republic, Brill, Leiden/Netherlands, 2014. ss. 172-184, 203s.

3. M. Brett Wilson, Translating the Qur'an in an Age of Nationalism: Print Culture and Modern Islam in Turkey, Oxford University Press, in association with the Institute of Ismaili Studies London 2014, ss 55-184.

4. Benjamin Flöhr, "Die Vita Elmalili Muhammed Hamdi Yazors (1878-1942)", Junge Perspektiven der Türkeiforschung in Deutschland, n Springer VS, Wiesbade 2014, ss. 61-78, 
5. İsmail Albayrak "A Turkish Exegesis of the Early Twentieth Century: Elmalili Muhammad Hamdi Yazır (d. 1942) and his Hak Dini Kur'an Dili" The Qur'an and its readers worldwide: contemporary commentaries and translations New York, Oxford University Press in association with The Institute of Ismaili Studies / Qur'anic studies series 14., London 2015, ss. -, 633s.

\section{Doktora Tezi;}

1. Fahri Gökcan, "Commentaire du Coran Par Elmalı'lı", Faculté des Lettres et Sciences Humaines (Paris), 1970, 237s. Elmalılı M. Hamdi Yazır'ın tefsiri ve tefsirciliği üzerine yapılmış bir çalışmadır (Yavuz, 1995: 62; Özel, 2001: 145).

2. Susan Gunasti, "Approaches to Islam in the Thoughts of Elmalili Muhammed Hamdi Yazir (18781942)", Princeton University, 2011.

Makale;

1. Muhammed Aydın, "Hamdi Yazır Elmalılı ve Menhecuhu Fi't-Tefsir/Elmalı1ı Hamdi Yazır ve Tefsirindeki Metodu”, (Arapça Makale), Havliyetü Külliyeti Usûlid-Dîn, sayı: 20, Kahire 2003.

2. Ismail Albayrak, "The Notions of Muhkam and Mutashābih in the Commentary of Elmali'li Muhammad Ḥamdi Yazir” Journal of Qur'anic Studies, 2003, Vol.5(1), p. 19-34.

3. Ismail Albayrak, "Turkish Exegeses of the Twentieth Century: Hak Dini Kur'an Dili" Islamic Studies, Vol. 43, No. 3 pp. 391-413, Autumn 2004.

4. M. Brett Wilson, “The First Translations of The Qur'an in Modern Turkey (1924-38)”, International Journal of Middle East Studies, Vol. 41(3), pp. 419-435, 2009.

5. Bilal Gökkır, "The Role of State Policies in Modern Qur'anic Exegesis in Turkey: Case of Elmal11 Muhammed Hamdi Yazır (1878-1942) and His Exegesis" say1: 25, ss. 133-145, Acta Asiatica Varsoviensia 2012.

6. Susan Gunasti, "Political Patronage and the writing of Qur' ān commentaries among the Ottoman Turks" Journal of Islamic Studies, Vol. 24(3), pp. 335-357, 2013.

7. Wilson M. Brett, "The Ulama's Best And Brightest: Elmalılı Muhammed Hamdi Yazır (1878/1942)", Translating the Qur'an in an Age of Nationalism: Print Culture and Modern Islam in Turkey, The İnstute of İsmaili Studies, ss. 226-228, London 2014.

8. K. Eith, "The mel Trend: The Rising Popularity of Qur'an Translations in Turkey in the 1990s and the Reactions of Turkish Academic Theologians", Journal of Qur'anic Studies, 2015, Vol. 17(3), p. 183-195.

\section{Sempozyun Bildirisi;}

1. Susan Gunasti, "Philosophy as Methodology: Elmal11 Muhammed Hamdi Yazır's Spiritualism and Religious Reform in the Late Ottoman Empire", Refonners and Intellectual Refonnulationin Contemporary Islam (29-30 January) London 2015.

\section{Değerlendirme ve Sonuç}

Değerlendirme ve sonuçlarla ilgili olarak elde edilen verileri aktarmaya geçmeden önce bu bilgilerin her ne kadar akademik bir araştırmanın gerektirdiği ciddiyet gösterilmeye çalış1lsa da taranan veri kaynaklarına ve bu kaynakların gelişmişlik düzeylerine bağlı olarak ortaya çıktığı belirtilmelidir. Taranan kaynakların kullanıcılar için hangi bilgilere erişime imkân tanıdıklarının yanı sıra kendileri açısından da verilerin doğru girilmiş olması önem arzetmektedir. Ayrıca eserlere ait künyelere ek olarak eserlerin içindeki başlıkların hatta tüm içeriğin ayrı ayrı taranabiliyor olması daha doğru sonuçlara 
ulaşılmasını sağlayacaktır. Literatürle ilgili bölümde değinildiği üzere "Elmalılı ve eserleri üzerine" geçmişte yapılan çalışmalar için belirtilen eksiklikler tarama imkânlarının gelişmesiyle yürütülen bu araştırma için de söz konusu olacaktır.

Literatür taraması şeklinde yapılan araştırmalardan elde edilen sonuçlara göre, Elmalılı ve eserleri üzerine kitap ve kitap bölümü kapsamında değerlendirilebilecek; 17 özgün kitap çalışması, 3 makale ve tezlerden üretilmiş kitap, 24'ü genel kitap bölümü, 68'si sempozyum kitabı bölümü olmak üzere 92 kitap bölümü ve 12 Elmalılı M. Hamdi Yazır'ın eserlerinden üretilmiş kitap çalışması bulunmaktadır.

Sadeleştirme kapsamında ele alınabilecek tefsir ve meâl çalışmalarında ise; Hak Dini Kur'an Dili tefsirine dair 9 sadeleştirme ve 2 ihtisar çalışması tespit edilmiş̧ir. Bunların yanı sıra; Hak Dini Kur'an Dili tefsirinden elde edilen 12 kelime meâline ve 2 nüzûl sıralı meâl çalışmasına ayrıca sadeleştirenin isminin belirtildiği 42 , belirtilmediği 16 sadeleştirme çalışması olmak üzere toplam 72 sadeleştirilmiş meâl çalışmasına ulaşılmıştır.

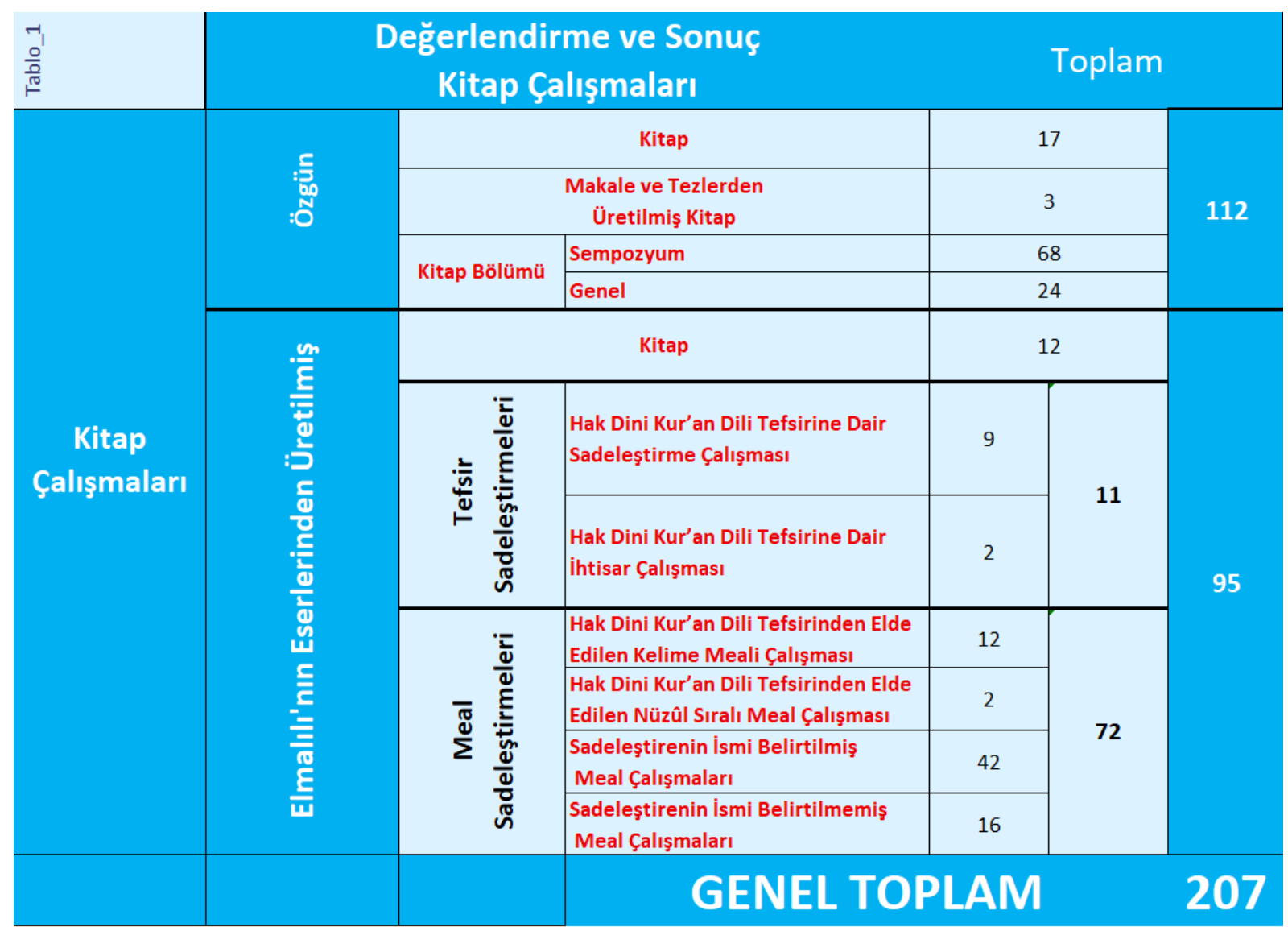

Elmalılı ve eserleri üzerine tamamlanmış lisans (bitirme) tezi, kapsamında değerlendirilebilecek; tefsir 60 , İslam hukuku 14 , kelam 14 , hadis 8 , İslam felsefesi 6 , tasavvuf 3 , din felsefesi 2 , din eğitimi 1 , İslam tarihi ve sanatları 1 , dinler tarihi 1 ve mezhepler tarihi 1 olmak üzere çeşitli alanlarda 111 lisans (bitirme) tezine ulaşılmıştır.

Elmalılı ve eserleri üzerine tamamlanmış yüksek lisans ve doktora tezi kapsamında ele alınabilecek; tefsir 27, kelam 20, İslam felsefesi 5, dinler tarihi 4, İslam hukuku 3, hadis 3, din felsefesi 3 , tasavvuf 2 , din psikolojisi 2 , din sosyolojisi 2 , din eğitimi 1 ve tarih 1 olmak üzere çeşitli alanlarda 
tamamlanmış 73 yüksek lisans çalışması tespit edilmiştir. 7'si tefsir alanında olmak üzere tamamlanmış 8 doktora çalışması bulunmaktadır.

Elmalılı ve eserleri üzerine devam eden yüksek lisans ve doktora tezi kapsamında değerlendirilebilecek; tefsir 14, kelam 7, din felsefesi 2, İslam tarihi ve sanatları 2, din eğitimi 1, İslam felsefesi 1 ve dinler tarihi 1 olmak üzere çeşitli alanlarda devam eden 28 yükssek lisans tez çalışması bulunmaktadır. Ayrıca biri tefsir diğeri hadis alanında devam eden 2 doktora tez çalışmasına ulaşılmıştır.

\begin{tabular}{|c|c|c|c|c|c|c|}
\hline & \multicolumn{3}{|c|}{$\begin{array}{c}\text { Değerlendirme ve Sonuç } \\
\text { Tezler }\end{array}$} & \multicolumn{3}{|c|}{ Toplam } \\
\hline \multirow{34}{*}{ Tezler } & \multirow{11}{*}{ 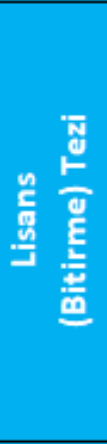 } & \multirow{11}{*}{ 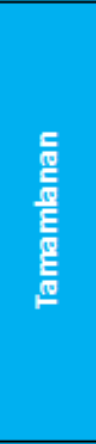 } & Tefsir Alanında & \multirow{2}{*}{\multicolumn{2}{|c|}{$\begin{array}{l}60 \\
14 \\
\end{array}$}} & \multirow{11}{*}{111} \\
\hline & & & İslam Hukuku Alanında & & & \\
\hline & & & Kelam Alanında & \multicolumn{2}{|c|}{14} & \\
\hline & & & Hadis Alanında & \multicolumn{2}{|c|}{8} & \\
\hline & & & İslam Felsefesi Alanında & \multicolumn{2}{|c|}{6} & \\
\hline & & & Tasavvuf Alanında & \multicolumn{2}{|c|}{3} & \\
\hline & & & Din Felsefesi Alanında & \multicolumn{2}{|c|}{2} & \\
\hline & & & Din Eğitimi Alanında & \multicolumn{2}{|c|}{1} & \\
\hline & & & \begin{tabular}{|l|} 
Dinler Tarihi Alanında \\
\end{tabular} & \multicolumn{2}{|c|}{1} & \\
\hline & & & íslam Tarihi ve Sanatları Alanında & \multicolumn{2}{|c|}{1} & \\
\hline & & & Mezhepler Tarihi Alanında & \multicolumn{2}{|c|}{1} & \\
\hline & \multirow{19}{*}{ 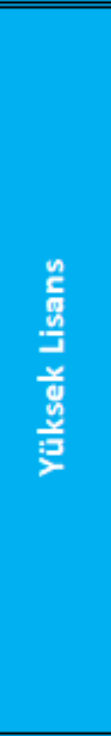 } & \multirow{12}{*}{ 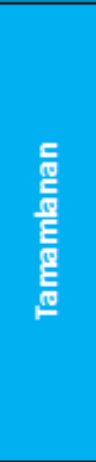 } & Tefsir Alanında & 27 & \multirow{12}{*}{73} & \multirow{19}{*}{101} \\
\hline & & & Kelam Alanında & 20 & & \\
\hline & & & İslam Felsefesi Alanında & 5 & & \\
\hline & & & \begin{tabular}{|l|} 
Dinler Tarihi Alanında \\
\end{tabular} & 4 & & \\
\hline & & & İslam Hukuku Alanında & 3 & & \\
\hline & & & Hadis Alanında & 3 & & \\
\hline & & & Din Felsefesi Alanında & 3 & & \\
\hline & & & Tasavvuf Alanında & 2 & & \\
\hline & & & Din Psikolojisi Alanında & 2 & & \\
\hline & & & Din Sosyolojisi Alanında & 2 & & \\
\hline & & & Din Eğitimi Alanında & 1 & & \\
\hline & & & Tarih alanında & 1 & & \\
\hline & & \multirow{7}{*}{ E } & Tefsir Alanında & 14 & \multirow{7}{*}{28} & \\
\hline & & & Kelam Alanında & 7 & & \\
\hline & & & \begin{tabular}{|l|} 
Din Felsefesi Alanında \\
\end{tabular} & 2 & & \\
\hline & & & İslam tarihi ve sanatları alanında & 2 & & \\
\hline & & & Din Eğitimi Alanında & 1 & & \\
\hline & & & İslam Felsefesi Alanında & 1 & & \\
\hline & & & Dinler Tarihi Alanında & 1 & & \\
\hline & \multirow{4}{*}{ 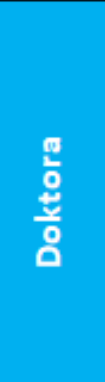 } & \multirow{2}{*}{$\frac{\text { 들 }}{\frac{10}{5}}$} & Tefsir Alanında & \multicolumn{2}{|c|}{7} & \multirow{4}{*}{10} \\
\hline & & & Diğer Alanda & \multicolumn{2}{|c|}{1} & \\
\hline & & \multirow{2}{*}{ 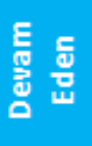 } & Tefsir Alanında & & & \\
\hline & & & Hadis Alanında & & & \\
\hline
\end{tabular}

Turkish Studies - Comparative Religious Studies

Volume 14 Issue 2, 2019 
Elmalılı M. Hamdi Yazır ve eserleriyle ilgili hakemli dergilerde yayımlanan makale kapsamında ele alınabilecek; tefsir 47, İslam hukuku 13, kelam 7, İslam felsefesi 5, Arap dili ve edebiyat1 4, din felsefesi 3, din eğitimi 2, hadis 2 , İslam tarihi ve sanatları 2, tasavvuf 1, din sosyolojisi 1, Yeniçağ tarihi 1, dinler tarihi 1 ve felsefe 1 olmak üzere çeşitli alanlarda 90 makale tespit edilmiştir. Hakemsiz dergilerde ve gazetelerde tefsir alanı daha yoğunluklu olmakla birlikte çeşitli alanlarda 44 makale bulunmaktadır. Ayrıca üç ansiklopedide 4 maddeye ulaşılmıştır.

\begin{tabular}{|c|c|c|c|c|c|}
\hline $\begin{array}{l}m_{1} \\
\frac{0}{0} \\
\frac{0}{10} \\
\frac{10}{t}\end{array}$ & \multicolumn{2}{|c|}{$\begin{array}{c}\text { Değerlendirme ve Sonuç } \\
\text { Makaleler }\end{array}$} & Makaleler & \multicolumn{2}{|c|}{ Toplam } \\
\hline \multirow{15}{*}{ Makaleler } & \multirow{16}{*}{ 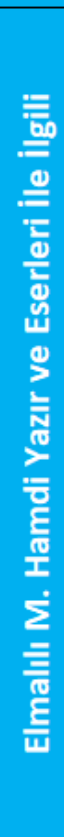 } & \multirow{14}{*}{ 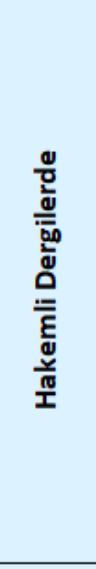 } & Tefsir Alanında & 47 & \multirow{14}{*}{90} \\
\hline & & & İslam Hukuku Alanında & 13 & \\
\hline & & & Kelam Alanında & 7 & \\
\hline & & & İslam Felsefesi Alanında & 5 & \\
\hline & & & Arap dili ve Edebiyatı Alanında & 4 & \\
\hline & & & Din Felsefesi Alanında & 3 & \\
\hline & & & Din Eğitimi Alanında & 2 & \\
\hline & & & Hadis Alanında & 2 & \\
\hline & & & İslam Tarihi ve SanatlarıAlanında & 2 & \\
\hline & & & Tasavvuf Alanında & 1 & \\
\hline & & & Din Sosyolojisi Alanında & 1 & \\
\hline & & & Yeniçağ Tarihi Alanında & 1 & \\
\hline & & & Dinler Tarihi Alanında & 1 & \\
\hline & & & Felsefe Alanında & 1 & \\
\hline & & 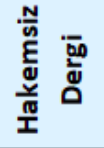 & $\begin{array}{l}\text { Tefsir Başta Olmak Üzere Birçok Farklı } \\
\text { Alanda }\end{array}$ & 44 & 44 \\
\hline $\begin{array}{l}\text { Ansiklopedi } \\
\text { Maddesi } \\
\end{array}$ & & & M. Hamdi Yazır Hakkında & 4 & 4 \\
\hline & & & GENEL T & & .38 \\
\hline
\end{tabular}

Elmalılı ve eserleriyle ilgili sempozyum bildirisi kapsamında değerlendirilebilecek; tefsir 21, din felsefesi 11, İslam hukuku 10, İslam tarihi ve sanatları 9, İslam felsefesi 8, kelam 5, hadis 3, tasavvuf 2 , mezhepler tarihi 2 , din eğitimi 1 , din sosyolojisi 1 , dinler tarihi 1 ve tarih 1 olmak üzere çeşitli alanlarda 6's1 sadece sunulmuş, 68'i sunulduktan sonra sempozyum kitaplarında kitap bölümü, 1'i ise hakemli bir dergide makale olmak üzere yayımlanmış toplamda 75 sempozyum bildirisine ulaşılmıştır. 


\begin{tabular}{|c|c|c|c|c|}
\hline 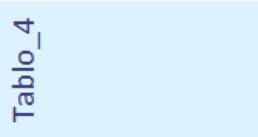 & \multicolumn{2}{|c|}{$\begin{array}{l}\text { Değerlendirme ve Sonuç } \\
\text { Sempozyum Bildirileri }\end{array}$} & \multicolumn{2}{|c|}{ Toplam } \\
\hline \multirow{13}{*}{$\begin{array}{l}\text { Sempozyum } \\
\text { Bildirisi }\end{array}$} & \multirow{13}{*}{ 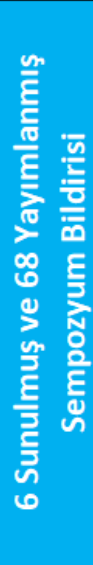 } & Tefsir Alanında & 21 & \multirow{13}{*}{75} \\
\hline & & Din Felsefesi Alanında & 11 & \\
\hline & & İslam Hukuku Alanında & 10 & \\
\hline & & İslam Tarihi ve Sanatları Alanında & 9 & \\
\hline & & İslam Felsefesi Alanında & 8 & \\
\hline & & Kelam Alanında & 5 & \\
\hline & & Hadis Alanında & 3 & \\
\hline & & Tasavvuf Alanında & 2 & \\
\hline & & Mezhepler Tarihi Alanında & 2 & \\
\hline & & Din Eğitimi Alanında & 1 & \\
\hline & & Din Sosyolojisi Alanında & 1 & \\
\hline & & Dinler Tarihi Alanında & 1 & \\
\hline & & Tarih Alanında & 1 & \\
\hline
\end{tabular}

Yabancı dilde yapılan çalışmalar 1 Almanca kitap, 3 İngilizce ve 2 Almanca olmak üzere 5 kitap bölümü, 1'i Fransızca diğeri İngilizce olmak üzere 2 doktora, 7'si İngilizce 1'i Arapça olmak üzere 8 makale ve 1 İngilizce sempozyum bildirisi olmak üzere toplamda yabancı dilde 17 yayın bulunmaktadır. Almanca, İngilizce ve Fransızca dillerinde Elmalılı üzerine kitap, doktora tezi, kitap bölümleri bulunurken Arapça olarak telif edilen sadece bir makalenin tespit edilebilmiş olması bu alandaki boşluğu göstermektedir.

\begin{tabular}{|c|c|c|c|c|}
\hline $\begin{array}{l}n_{1} \\
0^{\prime}\end{array}$ & $\begin{array}{l}\text { De } \\
\text { Yab }\end{array}$ & $\begin{array}{l}\text { e ve So } \\
\text { eki Yay }\end{array}$ & & \\
\hline \multirow{8}{*}{$\begin{array}{c}\text { Yabancı } \\
\text { Diller }\end{array}$} & $\begin{array}{c}\text { Kitap } \\
\text { Calıșması } \\
\end{array}$ & Almanca & 1 & 1 \\
\hline & \multirow{2}{*}{$\begin{array}{l}\text { Kitap } \\
\text { Bölümü }\end{array}$} & İngilizce & 3 & \\
\hline & & Almanca & 2 & \\
\hline & \multirow{2}{*}{ Doktora } & Ingilizce & 1 & \\
\hline & & Fransızca & 1 & \\
\hline & \multirow{2}{*}{ Makale } & İngilizce & 7 & \multirow{2}{*}{$\varepsilon$} \\
\hline & & Arapça & 1 & \\
\hline & $\begin{array}{c}\text { Sempozyum } \\
\text { Bildirisi }\end{array}$ & İngilizce & 1 & 1 \\
\hline
\end{tabular}

Turkish Studies - Comparative Religious Studies

Volume 14 Issue 2, 2019 
Böylelikle Elmalılı M. Hamdi Yazır ve eserleri üzerine yazılmış, Türkçe ve yabancı dillerde özgün kitap (17), kitap bölümleri (92), makale ve tezden üretilmiş kitap (3), Elmalılı M. Hamdi Yazır'ın eserlerinden üretilmiş kitap (12), tefsir ve meâl sadeleştirmeleri (83), bitirme tezleri (111), tamamlanmış ve tamamlanmamış yüksek lisans ve doktora tezleri (111), hakemli ve hakemsiz dergilerde yayımlanmış makaleler (134), ansiklopedi maddeleri (4), sempozyum bildirileri (75) olmak üzere- 642 künye tespit edilmiştir. Bunlardan tamamlanmamış doktora ve yüksek lisans tezleri (30) çıkarıldığında 612 yayına ulaşılmıştır.

Ulaşılan 612 eserden isimsiz çalışmalar (10) çıkarıldığında geriye kalan 602 eser 410 araştırmacı tarafından hazırlanmıştır. Bunlardan 47'si üç ve daha fazla yayına sahiptir. En fazla ürün ortaya koyan araştırmacılar 7'şer yayınla; Dücane Cündioğlu, Mustafa Özel, Nazif Öztürk, Necmi Atik, Sabri Yılmaz ve Tahsin Görgün'dür. Bunları 6'şar yayınla; Asım Cüneyd Köksal, Fatma Paksüt, İsmail Kara, Recep Kılıç, 5'er yayınla; Abdullah Çolak, Halis Albayrak, İbrahim Hilmi Karslı, İsmail Albayrak, Murat Kaya, Suat Yıldırım ve Vehbi Vakkasoğlu takip etmektedir.

Eserlerin tamamına yakınını tek yazarlı çalışmalar oluşturmaktadır. Ancak meal ve özellikle tefsir sadeleştirmelerinde çok yazarlı çalışmalarla karşılaşılmaktadır. En fazla yazarın iştirak ettiği çalışma 1992 yılında çelik-şura yayınları tarafından 9 cilt olarak yayımlanan 8 yazarlı tefsir sadeleştirmesidir. 


\begin{tabular}{|c|c|c|c|c|c|c|c|c|c|c|c|c|c|c|c|c|c|c|}
\hline $\begin{array}{l}0_{1} \\
\frac{\circ}{0} \\
\frac{0}{\circ}\end{array}$ & & NG & :OK & & $\begin{array}{l}\text { ec̆e } \\
8 \exists R\end{array}$ & $\begin{array}{l}\text { le } \\
\equiv\end{array}$ & $\begin{array}{l}\text { nd } \\
84\end{array}$ & Hín & ne & $\begin{array}{c}v e \\
A R\end{array}$ & $\begin{array}{l}\text { Son } \\
481\end{array}$ & $\begin{array}{l}\text { OUç } \\
\text { Rin }\end{array}$ & VAC & & $A R$ & & & \\
\hline & & & zgछün & & $\begin{aligned} & \begin{array}{r}\text { Elmallit'nin } \\
\text { Eserlerinden }\end{array} \\
&\end{aligned}$ & $\begin{array}{c}\text { Elmal } \\
\text { Elearle } \\
\text { - }\end{array}$ & & & ramananan & Teler & Devam Ede & En Tezler & & aleler & & pozyum & & \\
\hline & kitap & \begin{tabular}{|c|} 
Tezlerden \\
Üretilimis \\
Kitap
\end{tabular} & Sempozyur & Genel & Kitap & Tefsir & Meal & \begin{tabular}{|l|l|} 
Bitime \\
Tezi \\
\end{tabular} & \begin{tabular}{|c|} 
Yîktseke \\
Lisans \\
Tezi
\end{tabular} & \begin{tabular}{|c|}
$\begin{array}{c}\text { Doktorar } \\
\text { Teii }\end{array}$ \\
\end{tabular} & \begin{tabular}{|c|}
$\begin{array}{c}\text { Yüksek } \\
\text { Lisans Tezi }\end{array}$ \\
\end{tabular} & \begin{tabular}{c|} 
Doktora \\
Tezi
\end{tabular} & $\mid \begin{array}{c}\text { Hakkemili } \\
\text { Makale }\end{array}$ & $\begin{array}{c}\text { Hakemsiz } \\
\text { Makale }\end{array}$ & Sunulmus & Yaymmanmıs | & & \\
\hline \begin{tabular}{l|l}
1 & Dücane Cündioğlu \\
\end{tabular} & 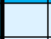 & 1 & & 1 & & & 1 & & & & & & & 4 & & & & 7 \\
\hline \begin{tabular}{l|l}
2 & Mustafa Özel \\
\end{tabular} & 1 & & & & & & 2 & & & 1 & & & 3 & & & & & 7 \\
\hline \begin{tabular}{l|l}
3 & Nazif Öztürk \\
\end{tabular} & & & 2 & & 1 & & & & & & & & 2 & & & 2 & & 7 \\
\hline \begin{tabular}{l|l}
4 & Necmi Atik \\
\end{tabular} & \begin{tabular}{|l|l}
1 \\
\end{tabular} & & 1 & & & & & & & & & & 4 & & & 1 & & 7 \\
\hline 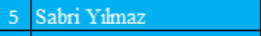 & & & 1 & & & & 2 & & 1 & & & & 2 & & & 1 & & 7 \\
\hline \begin{tabular}{l|l}
6 & Tahsin Görgün \\
\end{tabular} & & & 2 & & & & & 1 & & & & & 1 & 1 & & 2 & & 7 \\
\hline \begin{tabular}{l|l}
7 & Asm Cuneyd Köksal \\
\end{tabular} & \begin{tabular}{|l|l}
1 \\
\end{tabular} & 4 & & & & & & & & & & & 1 & & & & & 6 \\
\hline \begin{tabular}{l|l}
8 & Fatma Paksüt \\
\end{tabular} & & & 1 & & 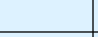 & & & & & & & & & 4 & & 1 & & 6 \\
\hline \begin{tabular}{l|l}
9 & İsmail Kara \\
\end{tabular} & 1 & & 2 & & & & & & & & & & 1 & & & 2 & & 6 \\
\hline \begin{tabular}{l|l}
10 & Recep Kihç \\
\end{tabular} & & & 2 & & 1 & & & & & & & & 1 & & & 2 & & 6 \\
\hline 11 Abdullah Çolak & 2 & & 1 & & & & & & & & & & 1 & & & 1 & & 5 \\
\hline \begin{tabular}{l|l}
12 & Halis Albayrak \\
\end{tabular} & & & 2 & & & & & & & & & & 1 & & & 2 & & 5 \\
\hline 13 İsmail Albayrak & & & & 2 & & & & & & & & & 2 & 1 & & & & 5 \\
\hline 14 Ibrahim H. Karsh & & & 2 & & & & & & & & & & 1 & & & 2 & & 5 \\
\hline 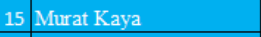 & & & 1 & & 3 & & & & & & & & & & & 1 & & 5 \\
\hline \begin{tabular}{l|l}
16 & Suat Yiddrum \\
\end{tabular} & & & & & & 1 & & & & & & & 1 & 3 & & & & 5 \\
\hline \begin{tabular}{l|l}
17 & Vehbi Valkasoğlu \\
\end{tabular} & & & & 1 & & & & & & & & & & 4 & & & & 5 \\
\hline 18 Abdulkadir Bayam, & & & & & & & & & & & & & 4 & & & & & 4 \\
\hline 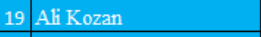 & & & 1 & & & & & & & & & & & & & 3 & & 4 \\
\hline 20 Hatice Toksōoz & & & 1 & & & & & & & & & & 2 & & & 1 & & 4 \\
\hline 21 Ismet Ersöz & & & 1 & & & & & 1 & & 1 & & & & & & 1 & & 4 \\
\hline \begin{tabular}{l|l}
22 & Mesut Okumuş \\
\end{tabular} & & & & 1 & & 1 & 1 & & & & & & 1 & & & & & 4 \\
\hline \begin{tabular}{l|l}
23 & M: Sadi Çöğenli \\
\end{tabular} & & & & & & 1 & 3 & & & & & & & & & & & 4 \\
\hline \begin{tabular}{l|l}
24 & Recep Bilgin \\
\end{tabular} & & & 2 & & & & & & & & & & & & & 2 & & 4 \\
\hline \begin{tabular}{l|l}
25 & Susan Gunasti \\
\end{tabular} & & & 1 & & & & & & & 1 & & & 1 & & 1 & & & 4 \\
\hline \begin{tabular}{l|l} 
26 Ali Yilmaz \\
\end{tabular} & & & 1 & & & & & & & & & & 1 & & & 1 & & 3 \\
\hline \begin{tabular}{l|l|}
27 & Abdurrahman Altuntaş \\
\end{tabular} & & & & & & & & & & & & & 2 & & & 1 & & 3 \\
\hline 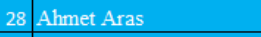 & & & 1 & & & & & & & & & & 1 & & & 1 & & 3 \\
\hline \begin{tabular}{l|l|}
29 & Cahit Baltaci \\
\end{tabular} & 1 & & & & & 1 & 1 & & & & & & & & & & & 3 \\
\hline 30 Durali Yilmaz & 1 & & & & & 1 & 1 & & & & & & & & & & & 3 \\
\hline \begin{tabular}{l|l}
31 & Huseyin Algül \\
\end{tabular} & & & 1 & & & & & & & & & & & 1 & & 1 & & 3 \\
\hline \begin{tabular}{l|l}
32 & Hüseyin Kurt \\
\end{tabular} & & & & & & & & & 1 & & & & 1 & & 1 & & & 3 \\
\hline \begin{tabular}{l|l}
33 & Hüsrev Subașı \\
\end{tabular} & & & 1 & & & & & & & & & & & 1 & & 1 & & 3 \\
\hline \begin{tabular}{l|l}
34 & Ibrahim Coşkun \\
\end{tabular} & & & 1 & & & & & & & & & & 1 & & & 1 & & 3 \\
\hline \begin{tabular}{l|l}
35 & İshak Özgel \\
\end{tabular} & 1 & & & & & & & & & & & & 2 & & & & & 3 \\
\hline \begin{tabular}{l|l}
36 & İsmail Çahş̧̧kan \\
\end{tabular} & & & 1 & 1 & & & & & & & & & & & & 1 & & 3 \\
\hline \begin{tabular}{l|l}
37 & Kasm Yayla \\
\end{tabular} & & & & & & 1 & 2 & & & & & & & & & & & 3 \\
\hline \begin{tabular}{l|l}
38 & Merter Rahmi Telkenaroğlu \\
\end{tabular} & & & 1 & 1 & & & & & & & & & & & & 1 & & 3 \\
\hline 39 M. Șinin Doğan & & & & & & & 3 & & & & & & & & & & & 3 \\
\hline \begin{tabular}{l|l}
40 & Muhittin Akguil \\
\end{tabular} & & & & 1 & & & & & & & & & & 1 & & 1 & & 3 \\
\hline \begin{tabular}{|l|l|}
41 & Mehmet S. Aydin \\
\end{tabular} & & & 1 & & & & & & & & & & 1 & & & 1 & & 3 \\
\hline \begin{tabular}{l|l}
42 & Nedim Yilmaz \\
\end{tabular} & & & & & & 1 & 2 & & & & & & & & & & & 3 \\
\hline \begin{tabular}{l|l}
43 & Nevzat Yasar Aşikoğlu \\
\end{tabular} & & & 1 & & & & & & & & & & 1 & & & 1 & & 3 \\
\hline \begin{tabular}{l|l}
44 & Suleyman H. Bolay \\
\end{tabular} & & & 1 & & & & & & & & & & 1 & & & 1 & & 3 \\
\hline \begin{tabular}{l|l}
45 & Sadrettin Gümüş \\
\end{tabular} & & & 1 & & & & 1 & & & & & & & & & 1 & & 3 \\
\hline \begin{tabular}{l|l}
46 & Șevket Topal \\
\end{tabular} & & & 1 & & & & & & & & & & 1 & & & 1 & & 3 \\
\hline \begin{tabular}{l|l}
47 & Yaşar Türkben \\
\end{tabular} & & & 1 & & & & & & & & & & 1 & & & 1 & & 3 \\
\hline TOPLAM & 9 & 5 & 36 & 8 & 5 & 7 & 19 & 2 & 2 & 3 & 0 & 0 & 42 & 20 & 2 & 39 & 0 & 199 \\
\hline
\end{tabular}


Elmalılı üzerine yazılan kitap, kitap bölümü ve hakemsiz dergilerde yayımlanan makalelerin birçoğu her ne kadar Elmalılı ve eserlerini tanıtmak adına önem arz etseler de ihtisas alanı ayrımı yapılmasına imkân tanımamaktadırlar. Araştırmamız sonucunda eser ismi, muhtevası, yazarların uzmanlık alanları gibi donelerle elde edilen 17 uzmanlık alanına göre bilim/ana bilim dalı ayrımına uygun olarak tanımlanabilecek; 111 bitirme tezi, 73 yüksek lisans tezi, 8 doktora tezi, devam eden 28 yüksek lisans tezi ve 2 doktora tezi, 90 hakemli dergilerde yer alan makale, 75 sempozyum bildirisi olmak üzere toplamda 387 eserin tespit edebildiğimiz dağılımı ise şöyledir;

Tefsir alanında tamamlanan 60 bitirme tezi, 27 yüksek lisans tezi, 7 doktora tezi, devam eden 14 yüksek lisans tezi ve 1 doktora tezi, 47 hakemli dergilerde yer alan makale ve 21 sempozyum bildirisi olmak üzere 177 eser bulunmaktadır.

Kelam alanında tamamlanan 14 bitirme tezi, 20 yüksek lisans tezi, devam eden 7 yüksek lisans tezi, 7 hakemli dergilerde yer alan makale ve 5 sempozyum bildirisi olmak üzere 53 eser tespit edilmiştir.

İslam hukuku alanında tamamlanan 14 bitirme tezi, 3 yüksek lisans tezi, 13 hakemli dergilerde yer alan makale ve 10 sempozyum bildirisi olmak üzere 40 esere ulaşılmıştır.

İslam felsefesi alanında 6 bitirme tezi, 5 yüksek lisans tezi, devam eden 1 yüksek lisans tezi, 5 hakemli dergilerde yer alan makale ve 8 sempozyum bildirisi olmak üzere 25 eser tespit edilmiştir.

Din felsefesi alanında 2 bitirme tezi, 3 yüksek lisans tezi, devam eden 2 yüksek lisans tezi, 3 hakemli dergilerde yer alan makale ve 11 sempozyum bildirisi olmak üzere 21 eser bulunmaktadır.

Hadis alanında tamamlanan 8 bitirme tezi, 3 yüksek lisans tezi, devam eden 1 doktora tezi, 2 hakemli dergilerde yer alan makale ve 3 sempozyum bildirisi olmak üzere 17 esere ulaşılmıştır.

İslam tarihi ve sanatları alanında tamamlanan 1 bitirme tezi, devam eden 2 yüksek lisans tezi, 2 hakemli dergilerde yer alan makale ve 9 sempozyum bildirisi olmak üzere 14 eser tespit edilmiştir.

Dinler tarihi alanında tamamlanan 1 bitirme tezi, 4 yüksek lisans tezi, devam eden 1 yüksek lisans tezi, 1 hakemli dergilerde yer alan makale ve 1 sempozyum bildirisi olmak üzere 8 eser bulunmaktadır.

Din eğitimi alanında tamamlanan 1 bitirme tezi, 1 yüksek lisans tezi, devam eden 1 yüksek lisans tezi, 2 hakemli dergilerde yer alan makale ve 1 sempozyum bildirisi olmak üzere 6 esere ulaşılmıştır.

Tasavvuf alanında tamamlanan 3 bitirme tezi, 2 yüksek lisans tezi, 1 hakemli dergilerde yer alan makale ve 2 sempozyum bildirisi olmak üzere 8 eser tespit edilmiştir.

Din sosyolojisi alanında tamamlanan 2 yüksek lisans tezi, 1 hakemli dergilerde yer alan makale ve 1 sempozyum bildirisi olmak üzere 4 eser bulunmaktadır.

Arap dili ve edebiyatı alanında hakemli dergilerde yer alan 4 makale telif edilmiştir. Mezhepler tarihi alanında 1 bitirme tezi ve 2 sempozyum bildirisi tespit edilmiştir. Din psikolojisi alanında 2 yüksek lisans tezi tamamlanmıştır. Tarih alanında tamamlanan 1 yüksek lisans tezi ve 1 sempozyum bildirisi bulunmaktadır. Yeniçağ tarihi alanında hakemli dergilerde yer alan 1 makale telif edilmiştir. Felsefe alanında hakemli dergilerde yer alan 1 makale bulunmaktadır. Batı' da tamamlanan 1 doktora çalışması ise ülkemizdeki anabilim/bilim dalı ayrımına tam uyum sağlamadığı için diğer alan olarak sınıflandırılmıştır. 


\begin{tabular}{|c|c|c|c|c|c|c|c|c|}
\hline \multirow[b]{2}{*}{ Bilim Dalı } & \multicolumn{8}{|c|}{$\begin{array}{l}\text { Değerlendirme ve Sonuç } \\
\text { ANABiLiM/BiLiM DALI }\end{array}$} \\
\hline & $\begin{array}{c}\text { Bitirme } \\
\text { Tezi }\end{array}$ & $\begin{array}{c}\text { Yüksek } \\
\text { Lisans } \\
\text { Tezi } \\
\end{array}$ & $\begin{array}{c}\text { Doktara } \\
\text { Lisans Tezi }\end{array}$ & $\begin{array}{l}\text { Yüksek } \\
\text { Lisans } \\
\text { Tezi }\end{array}$ & \begin{tabular}{|c|} 
Doktara \\
Lisans \\
Tezi
\end{tabular} & $\begin{array}{l}\text { Hakemli } \\
\text { Makale }\end{array}$ & Sempozyum & Toplam \\
\hline Tefsir & 60 & 27 & 7 & 14 & 1 & 47 & 21 & 177 \\
\hline Kelam & 14 & 20 & & 7 & & 7 & 5 & 53 \\
\hline İslam Hukuku & 14 & 3 & & & & 13 & 10 & 40 \\
\hline İslam Felsefesi & 6 & 5 & & 1 & & 5 & 8 & 25 \\
\hline Din Felsefesi & 2 & 3 & & 2 & & 3 & 11 & 21 \\
\hline Hadis & 8 & 3 & & & 1 & 2 & 3 & 17 \\
\hline İslam Tarihi ve Sanatları & 1 & & & 2 & & 2 & 9 & 14 \\
\hline Dinler Tarihi & 1 & 4 & & 1 & & 1 & 1 & 8 \\
\hline Tasavvuf & 3 & 2 & & & & 1 & 2 & 8 \\
\hline Din Eğitimi & 1 & 1 & & 1 & & 2 & 1 & 6 \\
\hline Din Sosyolojisi & & 2 & & & & 1 & 1 & 4 \\
\hline Arap Dili ve Edebiyatı & & & & & & 4 & & 4 \\
\hline Mezhepler Tarihi & 1 & & & & & & 2 & 3 \\
\hline Din Psikolojisi & & 2 & & & & & & 2 \\
\hline Tarih & & 1 & & & & & 1 & 2 \\
\hline Yeniçağ Tarihi & & & & & & 1 & & 1 \\
\hline Felsefe & & & & & & 1 & & 1 \\
\hline Diğer Alanda & & & 1 & & & & & 1 \\
\hline Toplam & 111 & 73 & 8 & 28 & 2 & 90 & 75 & 387 \\
\hline
\end{tabular}

Elmalılı ve eserleriyle ilgili yayınlar kapsamında değerlendirilebilecek ilk eser 1923 yılında yayımlanmıştır. Vefat senesi olan 1942 yılında ve 1955-1956 yıllarında hakkında yapılan çalışmalarda bir yoğunlaşmanın olduğu görülmüştür. 1989 yılından itibaren her yıl düzenli olarak Elmalılı hakkında yayın yapılmaya başlanmıştır. Eserleriyle ilgili telif hakkının kalktığı 1992 yılı ayrıca kendi adına sempozyumların düzenlendiği 1991 ve 2012 yılları ve bu sempozyumlardaki bildirilerin yayımlandıkları 1993 ve 2015 yılları yoğunlaşmanın görüldüğü diğer yıllardır. 2015 yılı ise 72 yayın ve 1 künyeyle 2012 yılı 63 yayın 5 künyeyle en fazla ürün verilen seneler olmuştur.

Tespit edilen 641 künyenin 30'unu tamamlanmamış yüksek lisans ve doktora tezleri oluşturmaktadır. Ayrıca tarihsiz 10 eser tespit edilmiştir. Böylelikle 602 eserin tekrarlanan basımlarıyla birlikte tarihleri belirlenebilen 640 yayının yıllara göre dağılımı şöyledir; 


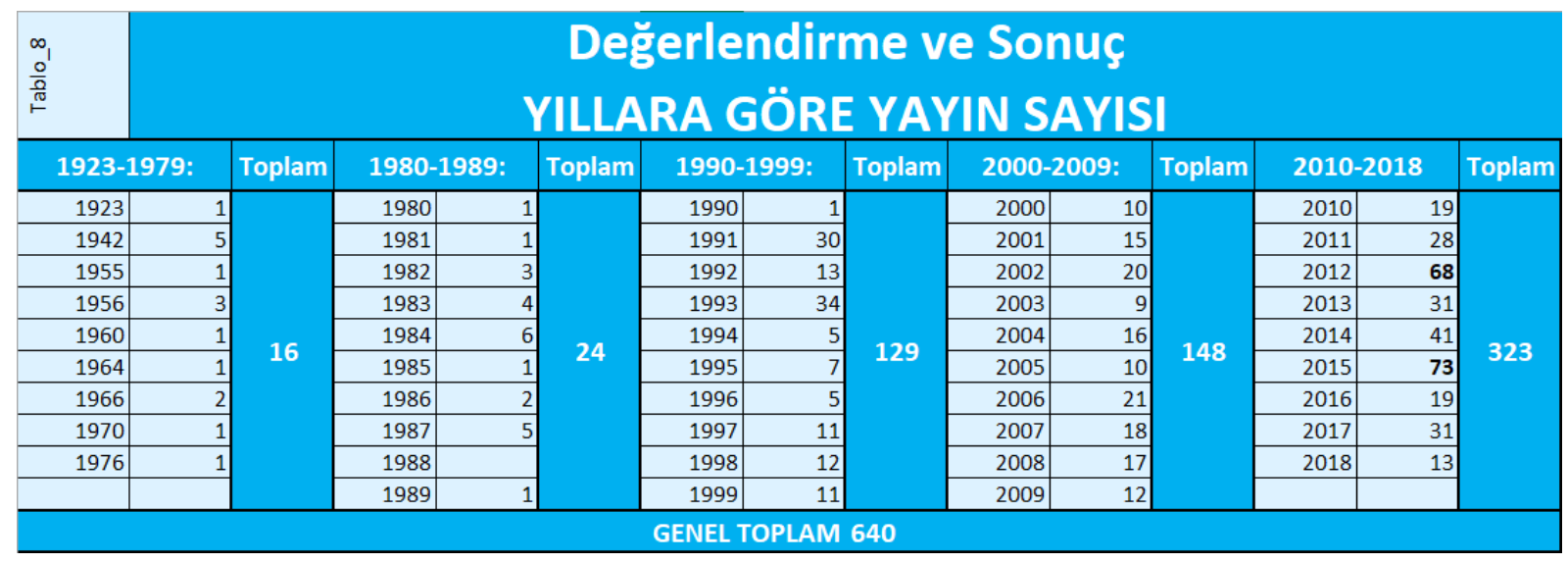

Elmalılı M. Hamdi Yazır ve eserleriyle ilgili hakemli dergilerde yayımlanan ilk makale Mehmed Emin Erişirgil tarafından, 1923 yılında Elmalılı M. Hamdi Yazır'ın Paul Janet ve Gabriel Seailles'in Histoire de la philosophie: les problems et les ecoles adlı eserinin Metâlib ve Mezâhib, isimli çevirisinin tanıtımıdır. ${ }^{113}$ Hakemsiz dergi ve gazetelerde yayımlanan ilk makale Ömer Rıza Doğrul'a ${ }^{114}$ ait olup, ilk ansiklopedi maddesi olarak İslam-Türk Ansiklopedisi'nde ${ }^{115}$ de ayrıca yayımlanmıștır (1942). İlk kitap bölümü İbnülemin Mahmut Kemal İnal (1955), ${ }^{116}$ ilk lisans (bitirme) tezi Muhittin Şamlıoğlu (1966), ${ }^{117}$ Elmalılı M. Hamdi Yazır hakkında ilk doktora çalışması yabancı dilde Fahri Gökcan (1970) ${ }^{118}$ Türkçede ise İsmet Ersöz (1985), ${ }^{119}$ ilk özgün kitap Suat Yıldırım, Asım Uysal, Kadir Kesici, Kamil Uzun, Mustafa Köseoğlu, Durali Yılmaz ve Cahit Baltacı (1982) ${ }^{120}$ tarafından yayımlanmıştır. Hak Dini Kur'an Dili tefsirinden elde edilen ilk meâl ve sadeleştirme çalışması Selahattin Kaya, Cahit Baltacı, Durali Y1lmaz, Kerim Aytekin, Muhtar Yazır'dan (1983) ${ }^{121}$ ayrica Hak Dini Kur'an Dili tefsirine dair ilk sadeleştirme çalışması M. Nur Çetin, Taha Parlar, İdris Şen, Mesut Okumuş, Mevlüt Uyanık, Orhan Atalay, Yusuf Canpolat, Alim Gür'den oluşan bir heyet tarafından (1992) $)^{122}$ yapılmıştır. İlk sempozyum bildirisini (1991) ve sempozyum kitabı bölümünü (1993) Fatma Paksüt, ${ }^{123}$ Hak Dini Kur'an Dili

\footnotetext{
113 Paul Janet ve Gabriel Seailles, Metâlib ve Mezâhib, Çev: Hamdi Bey (Elmalılı Hamdi Yazır), İstanbul Matbaa-i Âmire, 1339, Tanıtan: Mehmed Emin, Dârülfünun Edebiyat Fakültesi Mecmuası, cilt: III, say1: 2-3, ss. 159-174, İstanbul 1339 (1923). 114 Ömer Rıza Doğrul, "Müesssif Bir İrtihal”, 28 Mayıs 1942, Cumhuriyet Gazetesi, İstanbul 1942.

115 “İslâm Âlemi İçin Büyük Bir Ziyâ: Elmalılı M. Hamdi Efendinin Vefatı", İslam-Türk Ansiklopedisi, Mûhîtülmeaarif, cilt: I, 15 Haziran 1942/30, Cemâziyelevvel 1361, No: 36, İstanbul 1942.

116 İbnülemin Mahmut Kemal İnal, "Hamdi Efendi” Son Hattatlar, Maarif Matbaası İstanbul 1955, ss, 107-110, 827s.

${ }^{117}$ Muhittin Şamlıoğlu, ${ }^{117}$ "Elmalılı M. Hamdi Yazır: Hayatı ve Eserleri”, Ankara Üniversitesi İlahiyat Fakültesi, Ankara 1966, $18 \mathrm{~s}$.

${ }^{118}$ Fahri Gökcan, “Commentaire du Coran Par Elmalı'l1”, Faculté des Lettres et Sciences Humaines (Paris), 1970, 237s.

119 İsmet Ersöz, "Elmalılı Mehmed Hamdi Yazır ve Hak Dini Kur’ân Dili”, Selçuk Üniversitesi İlâhiyat Fakültesi Temel İslâm Bilimleri Anabilim Dalı Tefsir Bilim Dalı, Konya 1985, 200 y.

${ }^{120}$ Durali Yılmaz, Hak Dini Kur'an Dili Fihristi ve Lügati, Eser Neşriyat ve Dağıtım, İstanbul 1982, 702s.

${ }^{121}$ Elmalılı M. Hamdi Yazır, Hak Dini Kur'an Dili Meâli, Hazırlayanlar: Selahattin Kaya, Cahit Baltacı, Durali Yılmaz, Kerim Aytekin, Muhtar Yazır, Eser Neşriyat, İstanbul 1983, 604s.

${ }_{122}$ Elmalı1ı M. Hamdi Yazır, Hak Dini Kur'an Dili, (9 Cilt). Sadeleştirenler: M. Nur Çetin, Taha Parlar, İdris Şen, Mesut Okumuş, Mevlüt Uyanık, Orhan Atalay, Yusuf Canpolat, Alim Gür, Çelik-Şura Yayınları, İstanbul 1992.

Elmalılı M. Hamdi Yazır, Hak Dini Kur'ân Dili, (10 Cilt). Sadeleştirenler: Selahattin Kaya, Cahit Baltacı, Durali Yılmaz, Kerim Aytekin, Eser Neşriyat, İstanbul 1992.

Elmalılı M. Hamdi Yazır, Hak Dini Kur'ân Dili, (10 Cilt). Sadeleştirenler: İsmail Karaçam-Emin Işık-Nusrettin BolelliAbdullah Yücel, Azim Yayınları, İstanbul 1992.

${ }^{123}$ Fatma Paksüt, "Merhum Dayım Hamdi Yazır", Elmalılı M. Hamdi Yazır Sempozyumu, 4-6 Eylül 1991, Antalya/Elmalı; Elmalılı Muhammed Hamdi Yazır, TDV Yayınları, ss. 2-24, Ankara 1993, 338s.
} 
tefsirinden elde edilen ilk nüzûl sıralı meâl çalışmasını Mesut Okumuş (1994), ${ }^{124}$ Elmalılı'nın eserlerinden üretilmiş ilk kitabı Dücane Cündioğlu (1993) ${ }^{125}$ ilk yüksek lisans çalışmasını Nurettin Başyiğit (1996), ${ }^{126}$ yabancı dilde yayımlanan ilk makaleyi Muhammed Aydın (2003) ${ }^{127}$ Hak Dini Kur'an Dili tefsirine dair ilk ihtisar çalışmasını Ertuğrul Özalp (2006), ${ }^{128}$ Hak Dini Kur'an Dili tefsirinden elde edilen ilk kelime meâli çalışmasını Mustafa Özel (2006) ${ }^{129}$ te'lif etmiştir. Ayrıca yabancı dilde yayımlanan kitap bölümü Ursula Ragacs $(2012)^{130}$ ve ilk kitap Benjamin Flöhr (2015) ${ }^{131}$ tarafından hazırlanmıştır. Yabancı dilde ilk sempozyun bildirisini Susan Gunasti (2015) ${ }^{132}$ sunmuştur. Makale ve tezlerden üretilmiş ilk kitabı Mehmet Şirin Ayiş (2015) ${ }^{133}$ yayınlamıştır.

Yayınların yıllardaki yoğunlukları yayın türlerine göre değerlendirildiğinde; en fazla özgün kitap 2008, 2015 ve 2017 yıllarında 2'şer tane, makale ve tezden üretilmiş kitap 2017 yılında 2 tane, sempozyum kitap bölümü 1993 ve 2015 yıllarında 27'şer tane, genel kitap bölümü 2017 yılında 8 tane, Elmalılı M. Hamdi Yazır'ın eserlerinden üretilmiş kitap 1997 ve 1998 yıllarında 2'şer tane, tefsir sadeleştirmesi 1992 yılında 3 tane, meâl sadeleştirmesi 2011, 2012 ve 2013 yıllarında 12'şer tane, bitirme tezi 2002, 2014 ve 2015 y1llarında 10'ar tane, yüksek lisans tezi 2014 yılında 8 tane, hakemli dergilerde yayımlanmış makale 2015 yılında 19 tane, hakemsiz dergilerde yayımlanmış makale 1998 yılında 6 tane yayımlanmıştır. En fazla sempozyum bildirisi 2012 yılında 28 tane sunulmuştur. Doktora tezleri ve ansiklopedi maddelerinin farklı yıllarda 1'er tane tamamlanıp yayımlandıkları görülmüştür. Yayın yıllarını gösteren tabloda yayın türüne göre ilk ürün kırmızı renkle gösterilirken bir türe ait bir yılda en fazla verilen ürünü gösteren sayı kalın karakterle yazılmıştır.

\footnotetext{
${ }^{124}$ Elmalılı M. Hamdi Yazır, Nüzul Sırasına Göre Kur'an-ı Kerim Meâli, Hazırlayan: Mesut Okumuş, Birleşik Dağıtım, Ankara $1994,463 \mathrm{~s}$

${ }^{125}$ Elmalılı M. Hamdi Yazır, Kur'an-ı Kerim ve Meâli, Hazırlayan: Dücane Cündioğlu, İslamoğlu Yayınevi, İstanbul 1993, $604 \mathrm{~s}$.

${ }^{126}$ Nurettin Başyiğit, "Elmalı'da İlmî Tefsir”, Uludağ Üniversitesi Temel İslâm Bilimleri Anabilim Dalı Tefsir Bilim Dalı, Bursa 1996, $120 \mathrm{y}$.

127 Muhammed Aydın, "Hamdi Yazır Elmalılı ve Menhecuhu fi’t-Tefsir/Elmalılı Hamdi Yazır ve Tefsirindeki Metodu", (Arapça Makale), Havliyetü Külliyeti Usûlid-Dîn, sayı: 20, Kahire 2003.

${ }^{128}$ Elmalılı M. Hamdi Yazır, Muhtasar Hak Dini Kur'ân Dili: Meâl-Tefsir, Hazırlayan ve Notlandıran: Ertuğrul Özalp, İşaret Yayınları, İstanbul 2006, 1243s. ${ }^{128}$

${ }^{129}$ Elmalılı M. Hamdi Yazır, Kur'an-ı Kerim Renkli Kelime Meâli, Renklendirerek Yayına Hazırlayan: Mustafa Özel, Asır Ajans, İstanbul 2006, 624s.

130 Ursula Ragacs, "Elmal11 (1878-1942)" Religion übersetzen: Übersetzung und Textrezeption als transformation sphänomene von Religion, Grohmann, Marianne; Appel, Kurt; Danz, Christian; Potz, Richard; Rosenberger, Sieglinde; Walser, Angelika vd. Gottingen: Vandenhoeck \& Ruprecht 2012, ss. 212-213.

${ }^{131}$ Benjamin Flöhr, Ein traditionalistischer Korandeuter im Dienste des Kemalismus: Elmalili Muhammed Hamdi Yazir (18781942), Klaus Schwarz Verlag/(Islamkundliche Untersuchungen; Bd. 326.) Berlin, 2015, 561s.

${ }^{132}$ Susan Gunasti, "Philosophy as Methodology: Elmalılı Muhammed Hamdi Yazır's Spiritualism and Religious Reform in the Late Ottoman Empire", Refonners and Intellectual Refonnulationin Contemporary Islam (29-30 January) London 2015.

${ }^{133}$ Elmalılı Tefsirinde Tasavvuf, Rağbet Yayınları, İstanbul 2015, 312s.
} 


\begin{tabular}{|c|c|c|c|c|c|c|c|c|c|c|c|c|c|c|c|c|c|c|}
\hline $\begin{array}{l}\sigma_{1} \\
\frac{o}{0} \\
\frac{0}{\pi}\end{array}$ & & & & & $\begin{array}{r}\text { D } \\
\text { YLL }\end{array}$ & $\begin{array}{l}\text { Ded } \\
\text { L4 }\end{array}$ & $\begin{array}{l}\text { ğe } \\
\mathbf{R}\end{array}$ & le & $\begin{array}{l}\text { ndf } \\
\text { c\% }\end{array}$ & $\begin{array}{l}\text { frm } \\
\text { RE }\end{array}$ & $\begin{array}{l}\Theta V \\
Y A\end{array}$ & $\begin{array}{l}\text { e } S \\
\text { YI }\end{array}$ & $\begin{array}{l}\text { on } \\
T\end{array}$ & $\begin{array}{l}\text { Uç } \\
\text { ÜR }\end{array}$ & & & & \\
\hline$\sqrt{90}$ & & & trgǜn & & $\begin{array}{l}\text { Elmalit'nin } \\
\text { Eserlerinden }\end{array}$ & $\begin{array}{l}\text { Elmal } \\
\text { Eserle }\end{array}$ & & & namlanan & TTelerer & Devam Ed & Ilen Tezler & Mak & aleler & & sozyum & & \\
\hline$\frac{5}{5}$ & & \begin{tabular}{|l|} 
Makale vi \\
Tonterdete
\end{tabular} & $\begin{array}{l}\text { Kitap } \\
\text { Bollium }\end{array}$ & & & & & & & & & & & & & & | Maddesi & Toplam \\
\hline$>$ & || Kitap & $\begin{array}{l}\text { Uevereres } \\
\text { Uretilat } \\
\text { Kitap }\end{array}$ & Sempozyum & Genel & Kitap & Tefsir & Meal & $\begin{array}{l}\text { Bititime } \\
\text { Tezi }\end{array}$ & \begin{tabular}{|l} 
Yuiksek \\
Lisisns \\
Tezi
\end{tabular} & \begin{tabular}{|c|} 
Dohktora \\
Tezi
\end{tabular} & 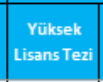 & \begin{tabular}{|c|c} 
Dohtora \\
Teri
\end{tabular} & \begin{tabular}{|l|}
$\begin{array}{c}\text { Hakememil } \\
\text { Malkale }\end{array}$ \\
\end{tabular} & \begin{tabular}{|l} 
Hakemsiz \\
Makale
\end{tabular} & Sunulmus & Yayımlanm & & \\
\hline 1923 & & & & & & & & & & & & & 1 & & & & & 1 \\
\hline 1942 & & & & & & & & & & & & & & 4 & & & 1 & 5 \\
\hline 1955 & & & & 11 & & & & & & & & & & & & & & 1 \\
\hline 1956 & & & & & & & & & & & & & & 3 & & & & 3 \\
\hline 1960 & & & & 1 & & & & & & & & & & & & & & 1 \\
\hline 1964 & & & & & & & & & & & & & 1 & & & & & 1 \\
\hline 1966 & & & & \begin{tabular}{|l|} 
\\
\end{tabular} & & & & 1 & & & & & & & & & & 2 \\
\hline 1970 & & & & & & & & & & 1 & & & & & & & & 1 \\
\hline 1976 & 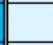 & & & & & & & 1 & & & & & & & & & & 1 \\
\hline 1980 & & & & 11 & & & & & & & & & & & & & & 1 \\
\hline 1981 & 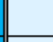 & & & & & & & 1 & & & & & & & & & & 1 \\
\hline 1982 & 1 & & & & & & & 1 & & & & & 1 & & & & & 3 \\
\hline 1983 & 1 & & & & & & 1 & 2 & & & & & & & & & & 4 \\
\hline 1984 & & & & & & & & 6 & & & & & & & & & & 6 \\
\hline 1985 & 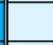 & & & & & & & & & 1 & & & & & & & & 1 \\
\hline 1986 & & & & & & & & 1 & 1 & & & & & & & & & 2 \\
\hline 1987 & 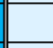 & & & 11 & & & & & & & & & & 4 & & & & 5 \\
\hline 1989 & & & & & & & & 11 & & & & & & & & & & 1 \\
\hline 1990 & & & & & & & & & 1 & & & & & & & & & 1 \\
\hline 1991 & 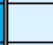 & & & & & & & & & & & & 2 & 1 & & 27 & & 30 \\
\hline 1992 & 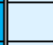 & & & & & 3 & & 11 & & & & & 4 & 5 & & & & 13 \\
\hline 1993 & 1 & & 27 & & 1 & & 1 & 1 & & & & & 1 & 2 & & & & 34 \\
\hline 1994 & & & & & & & 1 & & 1 & & & & & 3 & & & & 5 \\
\hline 1995 & 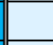 & & & & 1 & & & 1 & 3 & & & & 1 & & & & 1 & 7 \\
\hline 1996 & & & & & & & 2 & & 3 & & & & & & & & & 5 \\
\hline 1997 & 1 & & 1 & & 2 & & & 2 & 3 & & & & & & & 1 & 1 & 11 \\
\hline 1998 & 1 & & & & 2 & & 1 & 2 & & & & & & 6 & & & & 12 \\
\hline 1999 & & & & & & & & 4 & 1 & 1 & & & 2 & 2 & & 1 & & 11 \\
\hline 2000 & & & 1 & & & & 3 & 4 & 2 & & & & & & & & & 10 \\
\hline 2001 & 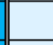 & & 1 & & 1 & & 2 & 5 & 2 & & & & 2 & 1 & & 1 & & 15 \\
\hline 2002 & & & & & 1 & & 4 & 10 & 2 & 1 & & & 1 & 1 & & & & 20 \\
\hline 2003 & 1 & & & & & 1 & 1 & & 2 & & & & 2 & & & 2 & & 9 \\
\hline 2004 & 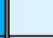 & & & & & & 3 & 5 & 4 & & & & 3 & 1 & & & & 16 \\
\hline 2005 & 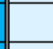 & & & $\begin{array}{ll}1 \\
\end{array}$ & 1 & & 4 & 1 & 1 & & & & 2 & & & & & 10 \\
\hline 2006 & 1 & & & & & & 8 & 6 & 3 & & & & 2 & & & & 1 & 21 \\
\hline 2007 & & & 2 & 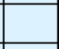 & & & 3 & 3 & 5 & & & & 1 & 3 & & 1 & & 18 \\
\hline 2008 & 2 & & 1 & & & & 2 & 1 & 7 & 1 & & & 2 & 1 & & & & 17 \\
\hline 2009 & & & & & & & 2 & 3 & 4 & & & & 1 & 2 & & & & 12 \\
\hline 2010 & & & & 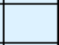 & & & 7 & 2 & 7 & & & & 2 & 1 & & & & 19 \\
\hline 2011 & 1 & & & 1 & 1 & & \begin{tabular}{|l|}
12 \\
\end{tabular} & 2 & 3 & 1 & & & 4 & 1 & & 2 & & 28 \\
\hline 2012 & 1 & & 2 & 2 & & 1 & 12 & 3 & 1 & & & & 12 & 1 & 5 & 28 & & 68 \\
\hline 2013 & 1 & & 1 & 1 & & 1 & 12 & 5 & 3 & & & & 5 & 1 & & 1 & & 31 \\
\hline 2014 & & & 1 & 4 & 1 & & 11 & 10 & 8 & & & & 3 & 1 & & 2 & & 41 \\
\hline 2015 & 2 & 1 & 27 & 2 & & & 7 & 10 & 3 & 1 & & & 19 & & 1 & & & 73 \\
\hline 2016 & & & & & & 1 & 2 & 8 & 2 & & & & 6 & & & & & 19 \\
\hline 2017 & 2 & 2 & & 8 & & & 2 & 5 & 1 & 1 & & & 9 & & & 1 & & 31 \\
\hline 2018 & 1 & & 3 & & 1 & 1 & 1 & 3 & & & & & 1 & & & 2 & & 13 \\
\hline $\begin{array}{l}\text { Devam } \\
\text { Eden }\end{array}$ & & & & & & & & & & & 28 & 2 & & & & & & 30 \\
\hline Tarihsiz & & & 1 & & & 1 & 8 & & & & & & & & & & & 10 \\
\hline$\overline{\text { TOPLAN }}$ & 17 & 3 & 68 & 24 & 12 & 9 & 112 & 111 & 73 & 8 & 28 & 2 & 90 & 44 & 6 & 69 & 4 & 680 \\
\hline
\end{tabular}


1953-2015 yılları arasında Türkiye ilahiyat fakültelerinde yapılan yüksek lisans ve doktora tezlerinin oranına bakıldığında 10354/2900'dür (Erünsal vd. 2017: 10). Elmalılı ile ilgili olarak Türkiye'de tamamlanan yüksek lisans ve doktora tezlerinin oranı ise 73/6'dır. Bu oran farklılığı diğer konularda yapılan doktoralara oranla Elmalılı'nın ve eserlerinin yüksek lisansta yaklaşık olarak üç kat fazla tercih edildiğini ortaya koymaktadır. Bu oran farklılığına, eser dilinin Türkçe olması, sadeleştirmelerin araştırma imkânını kolaylaştırması, kuruluşların ve danışmaların öğrencilere kendi kültürlerini tanıma imkânı sunmaya çalışmaları ayrıca dini ve kültürel zenginliklerimize sahip çıkma gibi saikler sebep olarak gösterilebilir.

Bitirme tezleri 6 üniversite ve 1 Diyanet Eğitim Merkezi'nde yapılmıştır. Bu kurumlar ve tez sayıları ise: Atatürk Üniversitesi; 55, Ankara Üniversitesi; 39, İstanbul Üniversitesi; 8, Hitit Üniversitesi; 5, Cumhuriyet Üniversitesi; 2, Marmara Üniversitesi; 1 ve Diyanet Eğitim Merkezi’nde; 1 tanedir.

Yüksek lisans ve doktora tezleri 2'si Avrupa Ünivesitelerinde olmak üzere 24 Üniversitede yapılmıştır. Bu üniversiteler ve tez sayıları; Selçuk Üniversitesi'inde; 8, Uludağ Üniversitesi ve Ankara Üniversitesi'inde; 7'şer, Dokuz Eylül Üniversitesi, Harran Üniversitesi, Sakarya Üniversitesi ve Marmara Üniversitesi'inde 6'şar, Gazi Üniversitesi (Hitit) ve Süleyman Demirel Üniversitesi'inde 4'er yüksek lisans ve doktora tezi tamamlanmıştır. Dicle Üniversitesi, Cumhuriyet Üniversitesi, Rize Üniversitesi (Recep Tayyip Erdoğan), Atatürk Üniversitesi, Erciyes Üniversitesi ve Yüzüncü Y1l Üniversitesi'inde 3'er, Eskişehir Osmangazi Üniversitesi, Fatih Sultan Mehmet Vakıf Üniversitesi, Çukurova Üniversitesi, Kahramanmaraş Sütçü İmam Üniversitesi, Şırnak Üniversitesi, Fırat Üniversitesi, İstanbul Üniversitesi, Université Paris (Fransa) ve Princeton University'de (İngiltere) 1'er tane yüksek lisans ve doktora tezi tamamlanmıştır. Türkiye'deki üniversiteler ve Elmalılı üzerine yapılan tez sayıları, ünivesitelerin ilahiyat fakültelerinde diğer konularda tamamlanan tez sayıları (Erünsal vd. 2017: 17-18) ile kıyaslandığında bunun kolerasyonunun düşük olduğu gözlenmektedir. Bu sonuç bazı ünüversitelerde Elmalılı'nın daha fazla ele alındığııı bazılarında ise diğerlerine göre daha az konu edinildiğini ortaya koymaktadır.

2015 y1lında 353 olarak tespit edilen (Abay 2012: 296) araştırma sürecinde yapılan taramalarda günümüzde 400'lü rakamlara ulaşttğg görülen Türkçe meâllerin 83 tanesi Elmalılı'ya ait veya Elmalılı'nın tefsirinden elde edilmiş sadeleştirilme çalışmasıdır. Bu da Türkiye'de oluşan genel meâl literatürünün \%20'sinin Elmalılı'ya ve onun eserleri üzerine yapılan çalışmalara ait olduğunu göstermektedir.

Elmalılı'ya dair literatürün hem yazarların farklı zamanlarda aynı eseri yayımlamaları hem de aynı konunun farklı yazarlarca ele alınması dolayısıyla birçok tekrarı içerdiği görülmektedir.

$\mathrm{Bu}$ araştırmada Elmalılı ve eserlerine dair tekrarlanan basımlarıyla sayısı 680'e ulaşan 642 çalışmanın künyesine ulaşılmışıı. Bu veri, Elmalılı'nın literatürde üzerinde en fazla çalışma yapılan Türk müfessir olduğunu göstermektedir. Bugünden sonra da aynı alanda çalışmaların devam edeceği rahatlıkla söylenebilir. Bu araştırmanın, Elmalılı hakkında bundan sonra yapılacak çalışmalarda tekrardan kaçınılması, Elmalılı ve eserleri hakkında kendisinden görüş alınacak danışman ve uzmanların kimler olduğuna ulaşılması ve ilerde yapılacak çalışmalara yol göstermesi açısından önemli bir misyon eda edeceği ön görülmektedir.

\section{KAYNAKÇA}

Abay, M., 2012. "Türkçedeki Kur'an Meâllerinin Tarihi ve Kronolojik Bibliyografyası", Türkiye Araştırmaları Literatür Dergisi, cilt: X, say1: 19-20, ss. 231-301, İstanbul. 
Aydar, H., 1999. “Türklerde Kur'an Çalışmaları”, İstanbul Üniversitesi İlahiyat Fakültesi Dergisi, sayı: 1, ss. 159-235, İstanbul.

Bestil, A., 2004. "Elmalılı Tefsirindeki Hadislerin Tahrîci” (I-III. Ciltler), Selçuk Üniversitesi Temel İslâm Bilimleri Anabilim Dalı Hadis Bilim Dalı, Konya.

Büyüker, K., 2017. "Elmalılı Hamdi Yazır Bibliyografyası", Büyük Kur'an Mütefekkiri Elmalılı M. Hamdi Yazır, DİB Yayınları, ss. 587-615, Ankara.

Çalışkan, N., 2017. "Nüzûl Sırasına Göre Tefsir Yaklaşımının Kur'an Yorumuna Etkisi (Beyânu'l-Hak Örneği)", Mustafa Kemal Üniversitesi Sosyal Bilimler Enstitüsü Dergisi, Hatay, XIV. cilt, 30. say1, 398-422.

Ersöz, İ., 1985. “Elmalılı Mehmed Hamdi Yazır ve Hak Dini Kur’ân Dili”, Selçuk Üniversitesi İlâhiyat Fakültesi Temel İslâm Bilimleri Anabilim Dalı Tefsir Bilim Dalı, Konya.

Erünsal, İ, E., Ülker, M, B., Karayel, M, E., 2017. Illahiyat Fakülteleri Tezler Kataloğu (1953-2015), Türkiye Diyanet Vakfi İslâm Araştırmaları Merkezi (ISSAM). İstanbul.

Gözalan, B., 2007. "Elmalılı Tefsirindeki Hadislerin Tahrîci (VII, VIII ve IX. Ciltler)", Selçuk Üniversitesi Temel İslâm Bilimleri Anabilim Dalı Hadis Bilim Dalı, Konya.

Gözeler, E., 2009. “İlâhiyat Fakültelerinde Kur’ân ve Tefsir Çalışmaları”, Türk Bilimler Derlemeler Dergisi, say1; 1, ss. 91-103, Konya.

, 2016. "Zemahşerî Araştırmaları: Bir Literatür İncelemesi”, Kelam Araştırmaları Dergisi, cilt: XIV, sayı: 1, ss. 84-101, s. 96. Konya.

Kara, M., 2015. “Türkiye'de Kur'an ve Tefsir Araştırmaları (1960-1971)”, Marmara Üniversitesi Temel İslâm Bilimleri Anabilim Dalı Tefsir Bilim Dalı, Yüksek Lisans Tezi, İstanbul.

Kara, Ö., 2010. "Türkiye'de Tefsir Akademyasının Gelişim Süreci, Tarihsel Dönemler Akademik "Konu" Kategorilerinin Analizi ve Problemlerimiz", Editörler: Bilal Gökkır ve diğ.; Tarihten Günümüze Kur'an'a Yaklaşımlar, ss. 607-636, İlim Yayma Vakfi, İstanbul.

Koçyiğit, H., 2017. "1980-2017 Arası Telif ve Tercüme Matbu Türkçe Tefsirler Bibliyografyası", Karadeniz Teknik Üniversitesi Illahiyat Fakültesi Dergisi, cilt: IV, sayı: 2, ss. 9-52, Trabzon.

, 2017. "Günümüz Türkçe Kur'an Meâlleri Üzerine Bir Tasnif Denemesi”, İstanbul Üniversitesi Illahiyat Fakültesi Dergisi, sayı: 37, ss. 79- 121, (Aralık) İstanbul.

Mertoğlu, M, S., 2011. “Osmanlı ve Cumhuriyet Dönemi Kur’an ve Tefsir Literatürüne Toplu Bir Bakış -Birincil Eserler ve Onlara Dair İncelemeler-”, Türkiye Araştırmaları Literatür Dergisi, cilt: IX, say1: 18, ss. 9-66, İstanbul.

Özel, M., 1999. "Elmalı1ı ile Mevdudi'nin Tefsirlerine Karşılaştırmalı Bir Yaklaşım”, Dokuz Eylül Üniversitesi İlâhiyat Fakültesi Temel İslâm Bilimleri Anabilim Dalı Tefsir Bilim Dalı, İzmir.

,2001. “Hak Dini Kur'ân Dili Üzerine Yapılan Akademik Çalışmalar”, İslâmî Araştırmalar Dergisi, cilt: XIV, say1: 1, ss. 145-149, Ankara.

Özgel, İ., 2012. "Elmalılı Muhammed Hamdi Yazır'ın Tefsiri ve Hakkında Yapılmış Çalışmalar Bibliyografyası", Türkiye Araştırmaları Literatür Dergisi, cilt: X, sayı: 19-20, ss. 327-362, İstanbul.

Öztürk, M., 2011. “II. Meşrutiyet’ten Günümüze Kur'an Meâlleri”, Türkiye Araştırmaları Literatür Dergisi, cilt: IX, say1: 18, ss. 139-189, İstanbul. 
Sarıtaş, K., 2016. "Muhammed Hamdi Yazır'ın Ruh Anlayışı”, Turkish Studies - International Periodical for the Languages, Literature and History of Turkish or Turkic, say1/volume: 11 Issue 12, ss. 181-204, ISSN: 1308-2140, www.turkishstudies.net, DOI Number: http://dx.doi.org/10.7827/TurkishStudies.8020, Ankara-Turkey.

Tekiner, S., 2006. "Elmalılı Tefsirindeki Hadislerin Tahrîci (IV, V, VI. Ciltler)" Selçuk Üniversitesi Temel İslâm Bilimleri Anabilim Dalı Hadis Bilim Dalı, Konya.

Tuncer, F., 2012. "Tefsir Üzerine Yapılan Çalışmalar Üzerine Bir Değerlendirme”, Sakarya Üniversitesi Illahiyat Fakültesi Dergisi, sayı: 26, ss. 149-177, s. 162, Sakarya.

Yavuz, Y, Ş., 1995. "Elmalı1ı Muhammed Hamdi Yazır”, DİA, TDV Yay., c. XI, ss. 57-62, İstanbul.

\section{İnternet Kaynakları}

http://ktp.isam.org.tr/ (erişim: 29 Ekim 2018).

http://ktp.isam.org.tr/?url=tezilh/findrecords.php (erişim: 29 Ekim 2018).

http://ktp.isam.org.tr/?url=makaleilh/findrecords.php (erişim: 29 Ekim 2018).

https://kasif.mkutup.gov.tr/ (erişim: 14 Kasım 2018).

http://kutuphane.ankara.edu.tr/?page_id=93 (erişim: 29 Ekim 2018).

http://katalog.marmara.edu.tr/yordambt/yordam.php (erişim: 14 Kasım 2018).

http://www.toplukatalog.gov.tr/index.php?cwid=2 (erişim: 29 Ekim 2018).

https://hollis.harvard.edu/primo-explore/search?vid=HVD2\&sortby=rank\&lang=en_US (erişim: 29 Ekim 2018).

https://en.pisai.it/library/library-assets/catalogue/ (erişim: 27 Ekim 2018).

http://www.soas.ac.uk/library/ (erişim: 29 Ekim 2018).

http://staatsbibliothek-berlin.de/ (erişim: 29 Ekim 2018).

http://www.oxlit.co.uk/ (erişim: 29 Ekim 2018).

http://www.jstor.org/ (erişim: 29 Ekim 2018).

http://www.mku.edu.tr/departments.aspx?birim=83 (erişim: 29 Ekim 2018).

http://katalog.ankara.edu.tr/uhtbin/cgisirsi/?ps=VSenB9Hwkw/MAIN/45890107/123 (erişim: 29 Ekim 2018).

http://platform.almanhal.com/ (erişim: 29 Ekim 2018).

https://docplayer.biz.tr (Erişim 30 Mart 2019). 